\title{
De Limburgse arbeidsmarkt 2000-2004
}

Citation for published version (APA):

de Grip, A., Diephuis, B. J., \& Nekkers, G. J. A. (2001). De Limburgse arbeidsmarkt 2000-2004:

Statistische bijlage. Researchcentrum voor Onderwijs en Arbeidsmarkt, Faculteit der Economische Wetenschappen. ROA Reports No. 1B https://doi.org/10.26481/umarep.200101B

Document status and date:

Published: 01/01/2001

DOI:

10.26481/umarep.200101B

Document Version:

Publisher's PDF, also known as Version of record

\section{Please check the document version of this publication:}

- A submitted manuscript is the version of the article upon submission and before peer-review. There can be important differences between the submitted version and the official published version of record.

People interested in the research are advised to contact the author for the final version of the publication, or visit the DOI to the publisher's website.

- The final author version and the galley proof are versions of the publication after peer review.

- The final published version features the final layout of the paper including the volume, issue and page numbers.

Link to publication

\footnotetext{
General rights rights.

- You may freely distribute the URL identifying the publication in the public portal. please follow below link for the End User Agreement:

www.umlib.nl/taverne-license

Take down policy

If you believe that this document breaches copyright please contact us at:

repository@maastrichtuniversity.nl

providing details and we will investigate your claim.
}

Copyright and moral rights for the publications made accessible in the public portal are retained by the authors and/or other copyright owners and it is a condition of accessing publications that users recognise and abide by the legal requirements associated with these

- Users may download and print one copy of any publication from the public portal for the purpose of private study or research.

- You may not further distribute the material or use it for any profit-making activity or commercial gain

If the publication is distributed under the terms of Article $25 \mathrm{fa}$ of the Dutch Copyright Act, indicated by the "Taverne" license above, 


\section{Statistische Bijlage \\ De Limburgse Arbeidsmarkt 2000-2004}

ROA-R-2001/1B

Researchcentrum voor Onderwijs en Arbeidsmarkt

Faculteit der Economische Wetenschappen en Bedrijfskunde Universiteit Maastricht

Maastricht, februari 2001 
Niets uit deze uitgave mag worden verveelvoudigd en/of openbaar gemaakt door middel van druk, fotokopie, microfilm, of op welke wijze ook, zonder voorafgaande schriftelijke toestemming van de directeur van het Researchcentrum voor Onderwijs en Arbeidsmarkt. In geval van overname van het datamateriaal moet telkens duidelijk als bron worden vermeld: "Researchcentrum voor Onderwijs en Arbeidsmarkt" of "ROA". Van publicaties waarin gebruik wordt gemaakt van gegevens uit deze Statistische bijlage ontvangen wij gaarne een exemplaar.

Hoewel de grootst mogelijke zorg is besteed aan de inhoud van dit rapport, kan het ROA in generlei opzicht verantwoordelijkheid op zich nemen voor eventuele onvolledigheden of onjuistheden.

ISBN 90-5321-301-5

Sec00155/GN 


\section{Inhoud}

\section{Voorwoord}

\section{De werkgelegenheidsstructuur in Limburg}

Tabel 1.1 Aantal werkenden per bedrijfssector, Limburg, gemiddelde 1998-1999

Tabel 1.2 Belangrijkste opleidingsniveaus van de werkenden per bedrijfssector, Limburg, gemiddelde 1998-1999

Tabel 1.3 Percentage jongeren (15-29 jaar) per bedrijfssector. Limburg. gemiddelde 1998-1999

Tabel 1.4 Percentage ouderen (50-64 jaar) per bedrijfssector, Limburg, gemiddelde 1998-1999

Tabel 1.5 Percentage vrouwen per bedrijfssector, Limburg. gemiddelde 1998-1999

Tabel 1.6 Percentage flexibel werk per bedriffssector, Limburg, gemiddelde 19981999

Tabel 1.7 Percentage deeltijdwerk per bedrijfssector, Limburg, gemiddelde 1998-1999

Tabel 1.8 Percentage zelfstandigen per bedrijfssector, Limburg, gemiddelde 19981999

Tabel 1.9 Aantal werkenden per beroepsgroep, Limburg. gemiddelde 1998-1999

Tabel 1.10 Percentage jongeren (15-29 jaar) per beroepssegment. Limburg. gemiddelde 1998-1999

Tabel 1.11 Percentage ouderen (50-64 jaar) per beroepssegment. Limburg, gemiddelde 1998-1999

Tabel 1.12 Percentage vrouwen per beroepssegment, Limburg, gemiddelde 1998-1999

Tabel 1.13 Percentage flexibel werk per beroepssegment, Limburg. gemiddelde 19981999

Tabel 1.14 Percentage deeltijdwerk per beroepssegment. Limburg, gemiddelde 1998 1999

Tabel 1.15 Percentage zelfstandigen per beroepssegment. Limburg. gemiddelde 19981999

Tabel 1.16 Aantal werkenden per opleidingstype. Limburg. gemiddelde 1998-1999

Tabel 118 Percentage jongeren (15-29 jaar) per opleidingssector. Limburg. gemiddelde 1998-1999

Tabel 1.19 Percentage ouderen (50-64) per opleidingssector. Limburg, gemiddelde 1998-1999

Tabel 1.20 Percentage vrouwen per opleidingssector. Limburg, gemiddelde 1998-1999

Tabel 1.21 Percentage flexibel werk per opleidingssector, Limburg. gemiddelde 19981999

Tabel 1.22 Percentage deeltijdwerk per opleidingssector, Limburg, gemiddelde 19981999

Tabel 1.23 Percentage zelfstandigen per opleidingssector, Limburg, gemiddelde 1998 1999 
Tabel 2.5 Niet-werkende werkzoekenden per beroepssegment en bemiddelingsfase, Limburg, april 2000

Tabel 2.6 Kenmerken niet-werkende werkzoekenden per beroepssegment, Limburg. april 2000

Tabel 2.7 Niet-werkende werkzoekenden per opleidingssector, Limburg, april 2000

Tabel 2.8 Niet-werkende werkzoekenden per opleidingssector en bemiddelingsfase. Limburg, april 2000

Tabel 2.9 Kenmerken niet-werkende werkzoekenden per opleidingssector, Limburg. april 2000

Tabel 2.10 Discrepanties per bedrijfssector, Limburg, april 2000

Tabel 2.11 Discrepanties per beroepssegment. Limburg, april 2000

Tabel 2.12 Discrepanties per opleidingssector, Limburg, april 2000

Tabel 2.13 Werkloosheid (in procenten) onder MBO-schoolverlaters per opleidingssector. Limburg en Nederland, 1999

Tabel 2.14 Intredewerkloosheid (langer dan 4 maanden, in procenten) onder MBOschoolveriaters per opleidingssector, Limburg en Nederland, 1999

Tabel 2.15 Gemiddeld bruto maandloon (in guldens) van MBO-schoolverlaters per opleidingssector. Limburg en Nederland, 1999

Tabel 2.16 Percentage MBO-schoolverlaters met een flexibele aanstelling per opleidingssector, Limburg en Nederland, 1999

Tabel 2.17 Percentage MBO-schoolverlaters dat in deeltijd werkt per opleidingssector, Limburg en Nederiand, 1999

Tabel 2.18 Onderbenutting van MBO-schoolverlaters per opleidingssector, Limburg en Nederland, 1999

Tabel 2.19 Percentage MBO-schoolverlaters dat buiten de eigen vakrichting werkzaam is per opleidingssector, Limburg en Nederland, 1999

3 De Limburgse arbeidsmarkt in 2001

Tabel 3.1 Verwachte uitbreidingsvraag per bedrijfssector (in percentage van de werkgelegenheid). Limburg. 2001

Tabel 3.2 Verwachte uitbreidingsvraag per beroepsgroep (in percentage van de werkgelegenheid), Limburg, 2001

Tabel 3.3 Verwachte netto vervangingsvraag per beroepsgroep (in percentage van de werkgelegenheid), Limburg. 2001

Tabel 3.4 Verwachte baanopeningen per beroepsgroep (in percentage van de werkgelegenheid). Limburg, 2001

Tabel 3.5 Verwachte arbeidsmarktinstroom van schoolverlaters per beroepsgroep (in percentage van de werkgelegenheid), Limburg. 2001

Tabel 36 Indicator Toekomstige Arbeidsmarktpositie naar Beroep (ITAB) en Indicator Toekomstige Knelpunten in de personeelsvoorziening per Beroep (ITKB) per beroepsgroep, Limburg, 2001

Tabel 3.7 Verwachte uitbreidingsvraag per opleidingstype (in percentage van de werkgelegenheid), Limburg, 2001

Tabel 3.8 Verwachte netto vervangingsvraag per opleidingstype (in percentage van de werkgelegenheid), Limburg، 2001

Tabel 3.9 Verwachte baanopeningen per opleidingstype (in percentage van de werkgelegenheid), Limburg, 2001 
Tabel 3.10 Verwachte arbeidsmarktinstroom van schoolverlaters per opleidingstype (in percentage van de werkgelegenheid), Limburg, 2001

Tabel 3.11 Indicator Toekomstige Arbeidsmarktperspectieven (ITA) en Indicator Toekomstige Knelpunten in de Personeelsvoorziening (ITKP) per opleidingstype, Limburg, 2001

4 De Limburgse arbeidsmarkt tot 2004

Tabel 4.1 Verwachte uitbreidingsvraag per bedrifssector, Limburg, 1999-2004 (percentage van de werkgelegenheid)

Tabel 4.2 Verwachte uitbreidingswraag per beroepsgroep, Limburg, 1999-2004 (percentage van de werkgelegenheid)

Tabel 4.3 Verwachte vervangingsvraag per beroepsgroep, Limburg, 1999-2004 (percentage van de werkgelegenheid)

Tabel 4.4 Verwachte baanopeningen per beroepsgroep. Limburg. 1999-2004 (percentage van de werkgelegenheid)

Tabel 4.5 Verwachte uitbreidingsvraag per opleidingstype, Limburg, 1999-2004 (percentage van de werkgelegenheid)

Tabell 4.6 Verwachte vervangingsvraag per opleidingstype, Limburg, 1999-2004 (percentage van de werkgelegenheid)

Tabel 4.7 Verwachte baanopeningen per opleidingstype, Limburg, 1999-2004 (percentage van de werkgelegenheid)

Tabel 4.8 Verwachte arbeidsmarktinstroom van schoolverlaters per opleidingstype, Limburg, 1999-2004 (percentage van de werkgelegenheid)

Tabel 4.9 Indicator Toekomstige Arbeidsmarktperspectieven (ITA) en Indicator Toekomstige Knelpunten in de Personeelsvoorziening (ITKP) naar opleiding, Limburg, 1999-2004

Tabel 4.10 Conjunctuurgevoeligheid en uitwijkmogelijkheden naar opleidingstype

\section{Classificaties}

Overzicht van opleidingstypen

Beroepsgroepen, volgens SBC ' 92

Beknopte Bedrijfsclassificatie SBI ' 93 



\section{Voorwoord}

Deze Statistische Bijlage bij het rapport De Limburgse arberdsmarkt 2000-2004 geeft een systematisch overzicht van de verwachte arbeidsmarktontwikkelingen en de actuele arbeidsmarktgegevens die ten grondslag liggen aan het hoofdrapport. Op basis van de in het kader van RAIL gegenereerde en verzamelde kwantitatieve informatie wordt een zo volledig mogelijk beeld gegeven, verbijzonderd naar 13 bedrijfssectoren, 127 beroepsgroepen en 113 opleidingstypen. Daarbij wordt gebruik gemaakt van de vanuit het informatiesysteem Onderwijs-Arbeidsmarkt van het ROA gegenereerde gegevens over de actuele werkgelegenheidsstructuur en de op korte en middellange termijn verwachte arbeidsmarktontwikkelingen. Deze arbeidsmarktinformatie wordt aangevuld met informatie over de niet-werkende werkzoekenden en de openstaande vacatures. Deze informatie is voor een belangrijk deel gebaseerd op het Primair Gemeenschappelijk Informatiesysteem van Arbeidsvoorziening Limburg. Daarnaast is gebruik gemaakt van de CBSvacature-enquête. Het hoofdrapport De Limburgse arbeidsmarkt 1999-2004 geeft het kader aan waarin de tabellen in deze Statistische Bijlage moeten worden geplaatst. Voor de gebruikte terminologie wordt verwezen naar de Verklarende woordenlijst achterin het hoofdrapport.

Deze Statistische Bijlage bestaat uit vier delen. In de eerste twee delen staat de actuele arbeidsmarktsituatie centraal. In het eerste deel wordt een beeld geschetst van de werkgelegenheidsstructuur in de provincie Limburg. Er wordt achtereenvolgens informatie gepresenteerd over de persoons- en functiekerımerken van de werkzame beroepsbevolking in Limburg naar bedrijfssector, beroepsgroep en opleidingstype (dan wel beroepssegment en opleidingssector). Tevens wordt telkens een vergelijking met de landelijke of provinciale structuur gegeven.

In het tweede deel staan de actuele discrepanties alsmede de actuele arbeidsmarktsituatie van de MBO-schoolverlaters centraal. In dit tweede deel wordt eerst aandacht geschonken aan de openstaande vacatures. Er wordt informatie gepresenteerd over het aantal openstaande vacatures. de vacaturegraad en het percentage langdurig openstaande vacatures naar bedrijfssector. beroepssegment en opleidingssector. Verder wordt er informatie gegeven over de niet-werkende werkzoekenden op de Limburgse arbeidsmarkt. Er wordt informatie gepresenteerd over het aantal niet-werkende werkzoekenden, het percentage langdurig werkzoekenden, de persoonskenmerken en de bemiddelbaarheid van de niet-werkende werkzoekenden naar beroepssegment en opleidingssector Aansluitend volgt een confrontatie van de aantallen openstaande vacatures en niet-werkende werkzoekenden. Dit maakt het mogelijk de kwantitatieve en kwalitatieve discrepanties op de Limburgse arbeidsmarkt in beeld te brengen. Hiervoor worden twee indicatoren gepresenteerd. De indicator voor de arbeidsmarktkrapte naar bedrijfssector. beroepssegment of opleidingssector geeft de verhouding weer tussen het aantal openstaande vacatures en het aantal direct bemiddelbare werkzoekenden Wanneer de indicator voor de arbeidsmarktkrapte groter is dan één, is er sprake van een tekort Wanneer de indicator daarentegen kleiner is dan èn, dan is er sprake van (enige) ruimte op het betreffende arbeidsmarktsegment. De knelpuntsindicator geeft aan in hoeverre een tekort aan direct-inzetbaar aanbod een kwantitatief of een kwalitatief karakter heeft. De indicator geeft de verhouding weer tussen het aantal openstaande vacatures dat niet door direct inzetbare werkzoekenden kan worden opgevuld en het aantal niet-werkende werkzoekenden met een wat grotere afstand tot de arbeidsmarkt. Naarmate deze verhouding groter wordt, heeft het tekort een meer kwantitatief karakter; het aantal niet-werkende werkzoekenden schiet eenvoudigweg tekort om aan de openstaande vraag te voldoen. Het tweede deel eindigt met informatie over de actuele arbeidsmarktpositie van MBO-schoolverlaters en is gebaseerd op gegevens uit het Schoolverlaters Informatie Systeem van het ROA. 
De in de delen drie en vier gepresenteerde tabellen geven een beeld van de te verwachten toekomstige ontwikkelingen op de Limburgse arbeidsmarkt naar beroepsgroep en opleidingstype. In deel drie worden de prognoses voor de korte termijn (d.w.z. voor 2001) gepresenteerd, terwijl in deel vier een overzicht wordt gegeven van de prognoses voor de middellange termijn (tot 2004), Deze laatste prognoses zijn ten opzichte van het vorige rapport ongewijzigd gebleven. De prognoses hebben zowel betrekiking op de vraagzijde als op de aanbodzijde van de arbeidsmarkt.

Aan de vraagzijde van de arbeidsmarkt wordt een onderscheid gemaakt tussen de uitbreidingsvraag en de vervangingsvraag, die tezamen de baanopeningen voor nieuwkomers op de arbeidsmarkt vormen. De indicator Toekomstige Arbeidsmarktperspectieven (ITA) en de Indicator Toekomstige Arbeidsmarktperspectieven naar Beroep (ITAB) geven de verhouding tussen vraag en aanbod weer. Daarbij moet worden bedacht dat een aanbodoverschot van mensen met een bepaalde opieidingsachtergrond of beroep niet per se tot werkloosheid van de betrokkenen hoeft te leiden. Een gebrekkige aansluiting tussen vraag en aanbod kan zich ook manifesteren in een hogere kans op werk buiten het eigen vakgebied of beneden het gevolgde opleidingsniveau, een lagere beloning, een grotere kans op een tijdelijk contract. etc. De Indicator Toekomstige Knelpunten in de Personeelsvoorziening (ITKP) en de Indicator Toekomstige Knelpunten in de Personeelsvoorziening naar Beroep (ITKB) bezien de implicaties van de verhouding tussen vraag en aanbod vanuit het gezichtspunt van de werkgever. Ook hierbij moet bedacht worden dat een aanbodtekort niet per se tot openstaande vacatures hoeft te leiden, maar ook aanpassingsprocessen op gang kan brengen.

De prognoses voor de perspectieven en knelpunten naar beroepsgroep hebben alleen betrekking op de elementaire, lagere en middelbare beroepen, terwijl de prognoses voor de perspectieven en knelpunten naar opleidingstype alleen betrekking hebben op het Basisonderwijs, de VMBO-opleidingen en de opleidingen op MBO-niveau. Voor de hogere beroepen en opleidingen heeft de arbeidsmarkt doorgaans een meer landelijk karakter. Voor de bedrijfssectoren en hogere beroepen en opleidingen worden alleen prognoses voor de uitbreidings- en vervangingsvraag en de daaruit resulterende baanopeningen gepresenteerd. Het is belangrijk op te merken dat dit aantal baanopeningen op zichzelf geen informatie geeft over de verwachte perspectieven en kneipunten, aangezien alleen de vraagzijde wordt belicht en geen confrontatie met de verwachte stromen aan de aanbodzijde van de arbeidsmarkt wordt gemaakt.

In deel vier is tevens informatie opgenomen over de structurele positie van opleidingen op de arbeidsmarkt. Het betreft hier de conjunctuurgevoeligheid van de werkgelegenheid en de uitwijkmogelijkheden op de arbeidsmarkt. Deze indicatoren hebben tot doel het perspectief in een breder kader te plaatsen. De prognoses van vraag en aanbod zijn uiteraard aan onzekerheid onderhevig. Bovendien zal een schoolverlater doorgaans een lange tijd op de arbeidsmarkt vertoeven. De structurele kenmerken beogen daarom een indicatie te geven van de risico's die men op een bepaald arbeidsmarktsegment loopt. Zo geeft de conjunctuurgevoeligheid aan in welke mate de werkgelegenheid voor het betreffende opleidingstype aan schommelingen onderhevig is, terwijl de uitwijkmogelijkheden aangeven in welke mate de werkenden afhankelijk zijn van de werkgelegenheidsontwikkelingen in eén beroep of juist uit kunnen wijken naar meerdere beroepsgroepen.

In de meeste tabellen wordt ook een kwalitatieve typering gegeven van de gepresenteerde informatie. Bij de actuele arbeidsmarktinformatie wordt tevens een indicatie gegeven van de trend in de afgelopen jaren. Bij de informatie over beroepsgroepen en opleidingstypen gaat het hierbij om de ontwikkeling in de periode 1995-1999 respectievelijk 1997-1999. De informatie over de trendmatige ontwikkeling heeft meestal betrekking op de ontwikkeling van het aandeel 
van de desbetreffende categorie. Alleen bij de tabellen 1.1, 1.9 en 1.16 gaat het om de ontwikkeling van het aantal werkenden.

De arbeidsmarktgegevens met betrekking tot de werkzame en niet-werkzame bevolking in het eerste deel zijn afkomstig uit de Enquête Beroepsbevolking (EBB) van het Centraal Bureau voor de Statistiek (CBS). Om de rabuustheid van de informatie te vergroten, hebben de gepresenteerde gegevens telkens betrekking op het gemiddelde van de jaren 1998 en 1999 . Om de herkenbaarheid van individuele respondenten te voorkomen, heeft het CBS de restrictie gesteld dat bij het publiceren van tweejaarlijkse gemiddelden alleen cijfers over categorieèn mogen worden gepresenteerd die betrekking hebben op tenminste 2.500 personen. In deel twee heeft het ROA, in het licht van de betrouwbaarheid van de informatie, de aantallen openstaande vacatures en niet-werkende werkzoekenden afgerond op 25-tallen. Bovendien is er een ondergrens van 25 gehanteerd. In de delen drie en vier is een ondergrens van 2.000 personen gehanteerd. Wanneer er in een beroepsgroep of opleidingstype minder dan 2.000 mensen werkzaam zijn, worden alleen kwalitatieve typeringen van de verwachte ontwikkelingen gepresenteerd.

De informatie naar bedrijfssector is gebaseerd op Standaard Bedrijfsindeling 1993 (SBI'93) van het CBS. De informatie naar beroepsgroep is gebaseerd op de Standaard Beroepsclassificatie 1992 (SBC'92) van het CBS. Hierbij is de 3-digitcode van het CBS gebruikt, waarbij code 471 is uitgesplitst in Bakkers en slagers en Procesoperators. Bovendien is bij de elementaire beroepen een uitsplitsing gemaakt naar zes beroepsgroepen. Tevens is afgeweken van de door het CBS gehanteerde namen. In plaats daarvan worden kortere beroepsnamen gebruikt. Voor de informatie naar opleidingstype is door het ROA een eigen classificatie ontwikkeld waarin opleidingen geclusterd zijn die in hoge mate hetzelfde beroependomein kennen. Deze classificatie is overigens wel gekoppeld aan de Standaard Onderwijs Indeling (SOI) van het CBS. Achterin deze Statistische Bijlage is een overzicht opgenomen van de gehanteerde classificaties. 


\section{De werkgelegenheidsstructuur in Limburg}

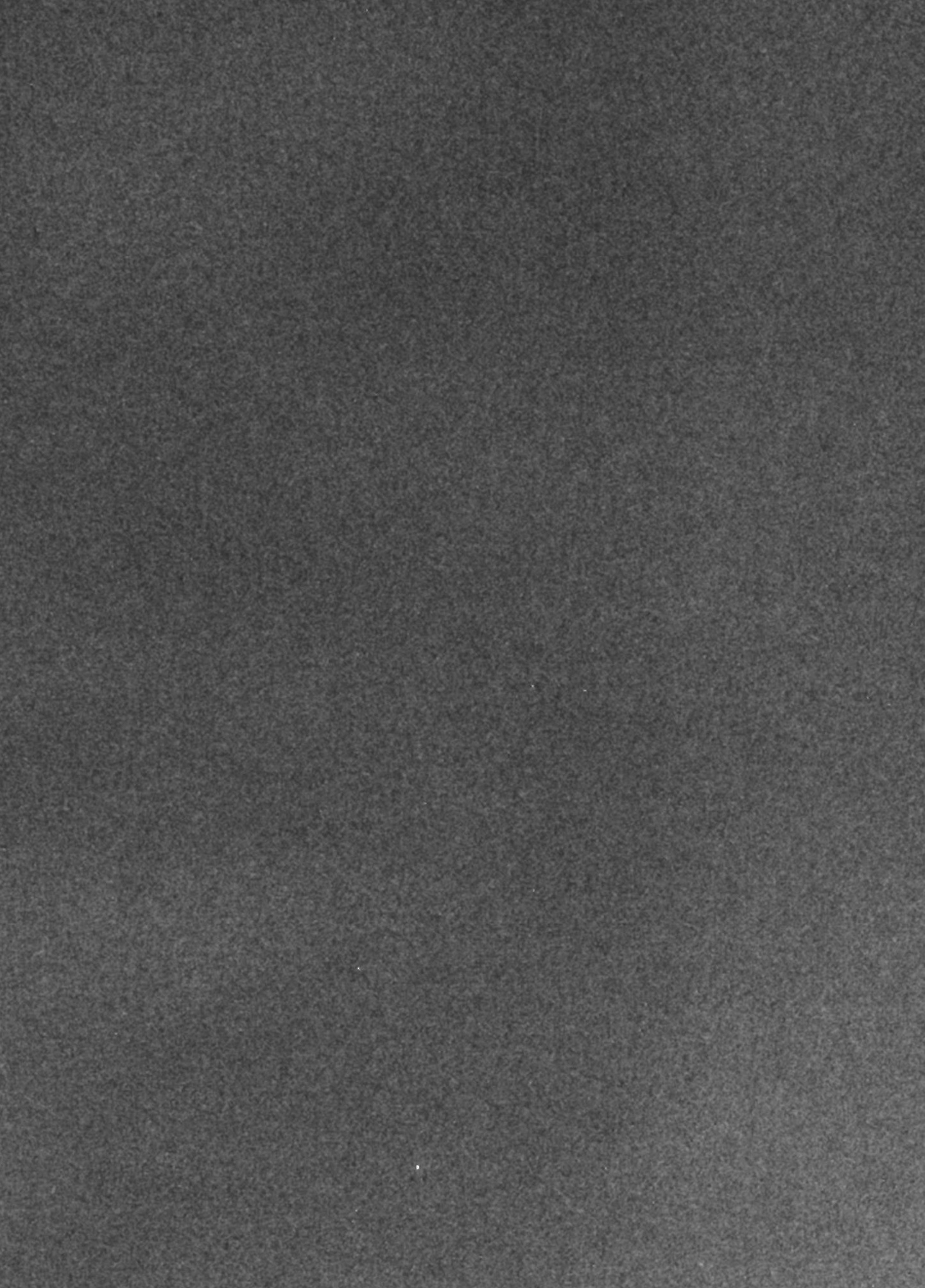




\section{Landbouw en visserij}

Tuinbouw

Veehouderii

Akkerbouw, bosbouw en visserij

Voeding

Vlees-en visverwerking

Overigle voedingingsproducten

Drank en tabaksproducten

\section{Chemie}

\section{Basischemie \\ Eindproducten chemie \\ Kunststofverwerking}

Metaal en elektrotechniek

Basismetaal

Metaalproducten

Machine-industrie

Elektratechniek

Transportmiddelen

\section{Overige industrie}

Textiel

Hout- en bouwmaterialen

Papier

Grafische industrie

\section{Energie}

Bouw en onroerend goed

Bouw

Exploitatie van onroerend goed

\section{Handel en reparatie}

Transport en communicatie

Scheep-en luchtvaart

Weg-en railvervoer

Communicatie

Bank-en verzekeringswezen

Bankwezen

Verzekeringswezen

Horeca en zakelijke dienstverlening

Horeca

Zakelijke dienstverlening

Overige commerciêle dienstverlening
15.000

$\begin{array}{ll}7.500 & \text { hoog } \\ 6.000 & \text { laag }\end{array}$

9.500

6.500

17.000

10.500

5.500

zeer hoog

hoog

stijgend

sterk stijgend

45.500

2.500

10.500

6.500

16.500

9.000

hoog

hoog

gemiddeld

zeer hoog

zeer hoog

constant

stijgend

sterk dalend

33.500

3.500

22.500

2.500

5.000

hoog

hoog

hoog

laag

4.500

gemiddeld

constant

constant

constant

sterk stijgend

dalend

33.000

29.500

3.000

gemiddeld

laag

dalend

dalend

6.500

gemiddeld

stijgend

26.500

19.000

7.000

gemiddeld gemiddeld

constant

dalend

15.000

8.000

7.000

zeer laag

gemiddeld

stijgend

dalend

62.000

16.000

35.500

gemiddeld

laag

gemiddeld sterk stijgend stijgend

stijgend 
Tabol 1.1 (vervolg)

Aantal werkenden per bedriffssector, Limburg, gemiddelde 1998-1999

\begin{tabular}{|c|c|c|c|}
\hline Bedriffssector & aantal & $\begin{array}{l}\text { Limburg t.o. } . \\
\text { Nederland }\end{array}$ & $\begin{array}{l}\text { trend } \\
1997-1999\end{array}$ \\
\hline Kwartaire diensten & 68.000 & & \\
\hline $\begin{array}{l}\text { Gezondsheidszorg } \\
\text { Overige kwartaire diensten }\end{array}$ & $\begin{array}{r}62.500 \\
5.500\end{array}$ & $\begin{array}{l}\text { gemiddeld } \\
\text { zeer laag }\end{array}$ & $\begin{array}{l}\text { constant } \\
\text { dalend }\end{array}$ \\
\hline Overheid en onderwijs & 60.500 & & \\
\hline $\begin{array}{l}\text { Onderwijs } \\
\text { Overheid }\end{array}$ & $\begin{array}{l}29.000 \\
31.500\end{array}$ & $\begin{array}{l}\text { gemiddeld } \\
\text { laag }\end{array}$ & $\begin{array}{l}\text { sterk stijgend } \\
\text { dalend }\end{array}$ \\
\hline Totaal & 466.500 & & \\
\hline
\end{tabular}

Bron: CBS/ROA 
Landbouw en visserij

VMBO

HAVOMWO/MBO

Voeding

VMBO

HAVOMMO/MBO

25

54

16

HAVONWV/MBO

$\mathrm{HBO}$

Metaal en elektrotechniek

Basisonderwijs
VMBO
HAVOMNO/MBO
HBO

Overige industrie

$$
\begin{aligned}
& \text { Basisonderwijs } \\
& \text { VMBO } \\
& \text { HAVOMMO/MBO }
\end{aligned}
$$

$\mathrm{HBO}$

\section{Energie}

HAVOMWO/MBO

Bouw en onroerend goed

Basisonderwijs

VMBO

HAVON WO/MBO

Handel en reparatie

Basisonderwijs

VMBO

HAVOMWO/MBO

$\mathrm{HBO}$

Transport en communicatie

$$
\begin{aligned}
& \text { Basisondenwijs } \\
& \text { VMBO } \\
& \text { HAVO MWO/MBO } \\
& \text { HBO }
\end{aligned}
$$

Bank-en verzekeringswezen stijgend

sterk dallend

sterk stijgend

sterk dalend

constant

sterk dalend

constant

stijgend

constant

stijgend

dalend

stijgend

stijgend

constant

constant

sterk dalend

sterk stijgend constant

dalend

sterk dalend

constant

constant

dalend

sterk dalend

constant

constant

stijgend

sterk dalend

sterk stijgend 
Horeca en zakelijke dienstverlening

$\begin{array}{lrl}\text { Basisonderwijs } & 9 & \text { sterk stijgend } \\ \text { VMBO } & 19 & \text { dalend } \\ \text { HAVOMWO/MBO } & 45 & \text { constant } \\ \text { HBO } & 19 & \text { constant } \\ \text { WO } & 9 & \text { stijgend }\end{array}$

Kwartaire diensten

\author{
VMBO \\ HAVONWO/MBO \\ HBO \\ WO
}

stijgend

dalend

sterk stijgend

dalend

Overheid en onderwijs
11

33

40

13

Totaal
Basisonderwijs

VMBO

HAVONWO/MBO

HBO

wo

$\begin{aligned} 9 & \text { constant } \\ 22 & \text { constant } \\ 45 & \text { constant } \\ 18 & \text { stijgend } \\ 6 & \text { constant }\end{aligned}$

dalend

dalend

stijgend

sterk dalend

Bron: CBS/ROA 
Tabel 1.3

Percentage jongeren (15-29 jaar) per bedrijfssector, Limburg, gemiddelde 1998-1999

\begin{tabular}{|c|c|c|c|c|}
\hline Bedrijfssector & $\%$ & typering & $\begin{array}{l}\text { Limburg to. } \mathrm{v} \text {. } \\
\text { Nederland }\end{array}$ & $\begin{array}{l}\text { trend } \\
1997-1999\end{array}$ \\
\hline $\begin{array}{l}\text { Landbouw en visserij } \\
\text { Voeding } \\
\text { Chemie } \\
\text { Meltaal en elektrotechniek } \\
\text { Overige industrie } \\
\text { Energie } \\
\text { Bouw en onroerend goed } \\
\text { Handel en reparatie } \\
\text { Transport en communicatie } \\
\text { Bank- en verzekeringswezen } \\
\text { Horeca en zakelijke dienstverlening } \\
\text { Kwartaire diensten } \\
\text { Overheid en onderwijs }\end{array}$ & $\begin{array}{r}21 \\
25 \\
17 \\
26 \\
18 \\
24 \\
35 \\
23 \\
22 \\
33 \\
22 \\
13\end{array}$ & $\begin{array}{l}\text { gemiddeld } \\
\text { gemiddeld } \\
\text { laag } \\
\text { hoog } \\
\text { laag } \\
\text { - } \\
\text { gemiddeld } \\
\text { zeer hoog } \\
\text { gemiddeld } \\
\text { gemiddeld } \\
\text { hoog } \\
\text { gemiddeld } \\
\text { zeer laag }\end{array}$ & $\begin{array}{l}\text { gemiddeld } \\
\text { gemiddeld } \\
\text { laag } \\
\text { zeer hoog } \\
\text { gemiddeld } \\
\text { gemiddeld } \\
\text { gemiddeld } \\
\text { gemiddeld } \\
\text { zeer laag } \\
\text { hoog } \\
\text { hoog } \\
\text { gemiddeld }\end{array}$ & $\begin{array}{l}\text { dalend } \\
\text { sterk dalend } \\
\text { dalend } \\
\text { dalend } \\
\text { dalend } \\
\text { stijgend } \\
\text { dalend } \\
\text { constant } \\
\text { sterk dalend } \\
\text { constant } \\
\text { sterk dalend } \\
\text { stijgend }\end{array}$ \\
\hline Totaal & 24 & - & - & constant \\
\hline
\end{tabular}

Bron: CBS/ROA 
Tabel 1.4

Percentage ouderen (50-64 jaar) per bedrijfssector, Limburg. gemiddelde 1998-1999

\begin{tabular}{|c|c|c|c|c|}
\hline Bedrijfssector & $\%$ & typering & $\begin{array}{l}\text { Limburg t.o.v } \\
\text { Nederiand }\end{array}$ & $\begin{array}{l}\text { trend } \\
1997-1999\end{array}$ \\
\hline Landbouw en visserij & 28 & zeer noog & gemiddeld & sterk stijgend \\
\hline Voeding & - & $\cdot$ & - & - \\
\hline Chemle & 18 & gemiddeld & gemiddeld & stijgend \\
\hline Metaal en elektrotechniek & 17 & gemiddeld & laag & sterk stijgend \\
\hline Overige industrie & 23 & hoog & hoog & constant \\
\hline Energie & - &. & - & - \\
\hline Bouw en onroerend goed & 20 & gemiddeld & hoog & sterk stijgend \\
\hline Handel en reparatie & 16 & laag & gemiddeld & stijgend \\
\hline Transport en communicatie & 17 & gemiddeld & gemiddeld & stijgend \\
\hline Bank-en verzekeringswezen & 18 & gemiddeid & zeer hoog & sterk stijgend \\
\hline Horeca en zakelike dienstverlening & 14 & zeer laag & gemiddeld & constant \\
\hline Kwartaire diensten & 14 & laag & zeer laag & stijgend \\
\hline Overheid en onderwijs & 24 & hoog & laag & stijgend \\
\hline Totaal & 18 & - & - & stijgend \\
\hline
\end{tabular}

Bron: CBS/ROA 
Tabel 1.5

Percentage vrouwen per bedrjifssector. Limburg, gemiddelde 1998-1999

\begin{tabular}{|c|c|c|c|c|}
\hline Bedrijfssector & $\%$ & typering & $\begin{array}{l}\text { Limburg t.o.v. } \\
\text { Nederiand }\end{array}$ & $\begin{array}{l}\text { trend } \\
1997-1999\end{array}$ \\
\hline $\begin{array}{l}\text { Landbouw en visserij } \\
\text { Voeding } \\
\text { Chemie } \\
\text { Metaal en elektrotechniek } \\
\text { Overige industrie } \\
\text { Energie } \\
\text { Bouw en onroerend goed } \\
\text { Handel en reparatie } \\
\text { Transport en communicatie } \\
\text { Bank- en verzekeringswezen } \\
\text { Horeca en zakelijke dienstverlening } \\
\text { Kwartaire diensten } \\
\text { Overheid en onderwijs }\end{array}$ & $\begin{array}{r}38 \\
35 \\
16 \\
15 \\
20 \\
- \\
9 \\
46 \\
23 \\
47 \\
46 \\
73 \\
37\end{array}$ & $\begin{array}{l}\text { gemiddeld } \\
\text { gemiddeld } \\
\text { laag } \\
\text { laag } \\
\text { gemiddeld } \\
\text { zeer laag } \\
\text { gemiddeld } \\
\text { gemiddeld } \\
\text { hoog } \\
\text { hoog } \\
\text { zeer hoog } \\
\text { gemiddeld }\end{array}$ & $\begin{array}{l}\text { zeer hoog } \\
\text { hoog } \\
\text { zeer laag } \\
\text { gemiddeld } \\
\text { laag } \\
\text { laag } \\
\text { hoog } \\
\text { gemiddeld } \\
\text { gemiddeld } \\
\text { gemiddeld } \\
\text { gemiddeld } \\
\text { gemiddeld }\end{array}$ & $\begin{array}{l}\text { stijgend } \\
\text { constant } \\
\text { sterk stijgend } \\
\text { constant } \\
\text { dalend } \\
\text { - } \\
\text { sterk dalend } \\
\text { constant } \\
\text { sterk stigend } \\
\text { dalend } \\
\text { constant } \\
\text { constant } \\
\text { constant }\end{array}$ \\
\hline Totaal & 38 & - & - & constant \\
\hline
\end{tabular}

Bron: CBS/ROA 
Tabel 1.6

Percentage flexibel werk per bedrijfssector, Limburg, gemiddelde 1998-1999

\begin{tabular}{|c|c|c|c|c|}
\hline Bedrijfssector & $\%$ & typering & $\begin{array}{l}\text { Limburg t.o.v. } \\
\text { Nederland }\end{array}$ & $\begin{array}{l}\text { trend } \\
1997-1999\end{array}$ \\
\hline Landbouw en visserij & - & - & - & - \\
\hline Voeding & - & - & - & - \\
\hline Chemie & - & - & - & - \\
\hline Metaal en elektrotechniek & 8 & gemiddeld & zeer hoog & sterk dalend \\
\hline Overige industrie & - & - & - & - \\
\hline Energie & - & - & - & - \\
\hline Bouw en onroerend goed & - & - & - & - \\
\hline Handel en reparatie & 9 & gemiddeld & laag & stijgend \\
\hline Transport en communicatie & 11 & hoog & hoog & stijgend \\
\hline Bank-en verzekeringswezen & - & - & - & - \\
\hline Horeca en zakelijke dienstverlening & 12 & zeer hoog & gemiddeld & stijgend \\
\hline Kwartaire diensten & 7 & laag & laag & dalend \\
\hline Overheid en onderwijs & 5 & laag & gemiddeld & stijgend \\
\hline Totaal & 9 & - & - & constant \\
\hline
\end{tabular}

Bron: CBSIROA

Van flexibel werk is sprake bij uitzendkrachten, oproepkrachten, invalkrachten, contracten zonder een vasit aantal arbeidsuren en indien geen vast dienstverband is overeengekomen. 
Tabel 1.7

Percentage deeltijdwerk ( 12 tot 32 uur) per bedrijssector, Limburg, gemiddelde 1998-1999

Bedrijfssector

$\% \quad$ typering

$\begin{array}{ll}\text { Limburg t.o.v. } & \text { trend } \\ \text { Nederiand } & 1997-1999\end{array}$

Landbouw en visserij

Voeding

Chemie

Metaal en elektrotechniek

Overige industrie

Energie

Bouw en onroerend goed

Handel en reparatie

Transport en communicatie

Bank-en verzekeringswezen

Horeca en zakelijke dienstverlening

Kwartaire diensten

Overheid en onderwijs

33

hoog

- -

-

8 zeer laag

$15 \quad$ laag

- -

10 laag

33 hoog

19 gemiddeld

23 gemiddeld

33 zeer hoog

56 gemiddeld

25 gemiddeld

27

zeer hoog stijgend

$-$

laag

stijgend

-

gemiddeld

hoog

gemiddeld

gemiddeld

hoog

gemiddeld

laag

stijgend

constant

constant

stijgend

dalend

constant

stijgend

constant

Bron: CBS/ROA 
Tabel 1.8

Percentage zelfstandigen per bedriffssector, Limburg, gemiddelde 1998-1999

\begin{tabular}{|c|c|c|c|c|}
\hline Bedriffssector & $\%$ & typering & $\begin{array}{l}\text { Limburg t.o.v. } \\
\text { Nederland }\end{array}$ & $\begin{array}{l}\text { trend } \\
1997-1999\end{array}$ \\
\hline Landbouw en visseri] & 51 & zeer hoog & gemiddeld & dalend \\
\hline Voeding & - & - & - & - \\
\hline Chemie & - & - & - & - \\
\hline Metaal en elektrotechniek & - & - & - & - \\
\hline Overige industrie & - & - & - & - \\
\hline Energie & - & - & - & - \\
\hline Bouw en onroerend goed & 12 & gemiddeld & laag & constant \\
\hline Handel en reparatie & 17 & gemiddeld & zeer hoog & constant \\
\hline Transport en communicatie & - & $=$ & - & - \\
\hline Bank-en verzekeringswezen & - & - & - & - \\
\hline Horeca en zakelifke dienstverlening & 20 & gemiddleld & gemiddeld & constant \\
\hline Kwartaire diensten & 7 & laag & gemiddeld & stijgend \\
\hline Overheid en onderwijs & - & - & $=$ & - \\
\hline Totaal & 11 & - & - & constant \\
\hline
\end{tabular}

Bron: CBS/ROA 


\section{Elementaire beroepen}

Kantoorhulpen, inpakkers en colporteurs
Agrarische hulparbeiders
Productiemedewerkers
Laders en lossers
Vakkenvullers
Interieurverzorgers

Lagere niet-specialistische beroepen

Ondersteunende administratieve hulpkrachten

\section{Lagere docenten sportvakken}

\section{Zweminstructeurs}

\section{Lagere agrarische beroepen}

\section{Agrarische arbeiders}

Landbouwmachinebestuurders en vissers

Lagere wiskundige, natuurwetenschappelijke beroepen

Laboratorium-assistenten

\section{Lagere technische beroepen}

43.500

\section{Conciërges \\ Bouwvakkers}

Weg-en waterbouwkundige arbeiders

Metaalarbeiders

Assembleurs

Monteurs en controleurs electrotechnische prod.

Grafisch productiepersoneel

Mechanisch operators

Confectie-arbeiders

\section{Lagere transportberoepen}

Chauffeurs

Lagere (para)medische beroepen

(Leerling) verpleeghulpen

Lagere administratieve, commerciële beroepen e.d.

Receptionisten en administratieve employés

Verzekeringsagenten

Verkopers

Lagere beveiligingsberoepen

Aspirant politieagenten, soldaten en beveiligingsagenten

2.500

2.500
34.000

\begin{tabular}{|c|c|c|}
\hline 4.000 & gemiddeld & dalend \\
\hline & - & 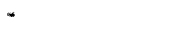 \\
\hline 7.500 & gemiddeld & dalend \\
\hline 7.000 & laag & stijgend \\
\hline 2.500 & hoog & sterk stijgend \\
\hline 11.500 & hoog & dalend \\
\hline
\end{tabular}

$\begin{array}{rll}14.000 & \text { hoog } & \text { dalend } \\ 9.500^{-} & - & - \\ 4.000 & \text { zeer hoog } & \text { sterk stijgend } \\ & \text { zeer hoog } & \text { sterk dalend } \\ 7.000^{\circ} & - & - \\ 3.000 & \text { zeer hoog } & \text { sterk stijgend } \\ & \text { zeer hoog } & \text { sterk dalend }\end{array}$

20.500

20.500 hoog stijgend

$\begin{array}{rll}16.500^{\circ} & \text { gemiddeld } & \text { constant } \\ 18.000^{\circ} & \text { gemiddeld } & \text { dalend }\end{array}$

laag

constant 
Hulpkrachten horeca en verzorging

Café- en snackbarhouders

\section{Middelbare docenten transport-en sportwakken}

Rij-instructeurs

Sportinstructeurs

Middelbare agrarische beroepen

Agrarische vakkrachten

Agrarische bedrijfshoofden

Middelbare wiskundige, natuurwetenschappelijke beroepen

Laboranten

Middelbare technische beroepen

Hoofden technische dienst

Aannemers en installateurs

Weg-en waterbouwkundige vakkrachten

Bankwerkers en lassers

Monteurs

Electronicamonteurs

Electromonteurs

Grafische vakkrachten

Procesoperators

Schoen-en kleermakers

Bakkers en slagers

Brandweerlieden

Middelbare transportberoepen e.d.

2.500

Schippers en conducteurs

Stewards

Administratieve transportemployés

Middelbare (para)medische beroepen

Verplegenden en doktersassistenten

Apothekersassistenten en medisch laboranten

Medisch secretaresses

Ziekenverzorgenden

Middelbare administratieve, commerciale beroepen $0 . d$.

62.500

Productieplanners

Assistent accountants

Commercieel employés

Technisch-commercieel employés

Programmeurs

Winkeliers
8.000

58.000

\begin{tabular}{|c|c|c|}
\hline 11.500 & gemiddeld & constant \\
\hline - & - & - \\
\hline - & & \\
\hline - & - & - \\
\hline - & - & - \\
\hline 8.000 & & \\
\hline - & - & - \\
\hline 8.000 & gemiddeld & constant \\
\hline
\end{tabular}

12.500

2.500

5.500

17.000

7.000

6.500

gemiddeld
gemiddeld
hoog
hoog

-

zeer laag

zeer hoog

stijgend

constant

dalend

dalend

constant

stijgend

-

-

$\begin{array}{rll}7.000 & \text { laag } & \text { dalend } \\ 3.500 & \text { hoog } & \text { sterk stijgend } \\ 5.500 & \text { hoog } & - \\ & \text { hog stijgend }\end{array}$

$\begin{array}{rll}3.500 & \text { laag } & \text { sterk stijgend } \\ 28.500 & \text { gemiddeld } & \text { dalend } \\ 16.500 & \text { laag } & \text { dalend } \\ - & - & - \\ 3.500 & \text { zeer laag } & \text { sterk stijgend } \\ 9.500 & \text { gemiddeld } & \text { constant }\end{array}$


Middelbare juridische, bestuurlijke beveiligingsberoepen

Juridisch en fiscaal medewerkers

$\begin{array}{lll}2.500 & \text { gemiddeld } & \text { sterik dalend } \\ 3.000 & \text { gemiddeld } & \text { sterk dalend }\end{array}$

Politie-agenten, onderofficieren, beveiligingsemployes

Middelbare taalkundige, culturele beroepen

Bibliotheekassistenten

Grafisch ontwerpers

Middelbare beroepen m.b.t. gedrag en maatschappij

Activiteitenbegeleiders en medewerkers

Arbeidsbemiddeling

Middelbare verzorgende beroepen e.d.

Verzorgend personeel

Bedrijfshoofden horeca

gemiddeld hoog

constant

17.500

\section{Leraar basisonderwijs}

Docenten exacte, medische verzorgende

vakken $\left(2^{\mathrm{e}} \mathrm{gr}\right.$.)

Docenten landbouw en techniek $\left(2^{*} \mathrm{gr}\right.$.)

Docenten economisch-administratieve

vakken ( $2^{*} \mathrm{gr}$.)

Docenten talen en expressie

Docenten sociale vakken $\left(2^{\mathrm{e}} \mathrm{gr}\right.$. $)$

Docenten $\left(2^{e} \mathrm{gr}\right.$.) zonder specialisatie

Onderwijskundig medewerkers

Hogere landbouwkundige beroepen

Millieuhygiënisten en agrarisch

Vertegenwoordigers

Hogere wiskundige, natuurwetenschappelijke beroepen

Technisch analisten

\section{Hogere technische beroepen}

Architecten en bouwkundig projectleiders
Projectleiders

Bedrijfshoofden metaalbewerking

Werktuigbouwkundig ontwerpers en hoofden

Technische dienst

Electrotechnisch ontwerpers en

Bedrijfshoofden

Procestechnologen

Technisch systeemanalisten 


\section{Hogere transportberoepen}

Vliegers, scheepskapiteins en leidinggevenden transport

Hogere (para)medische beroepen

Therapeuten en verpleegkundigen

Medisch analisten

Hogere administratieve, commerciële, econ. beroepen

Bedrilfshoofden

Organisatie-adviseurs

Assistent accountants

Commercleel medewerkers

Technisch-bedrijfskundig medewerkers

Systeemanalisten

Hogere juridische, bestuuriljke, beveiligingsberoepen

Juridisch bestuurlijk medewerkers

Politie-inspecteurs en afficieren

Hogere taalkundige, culturele beroepen

Tolken, vertalers en schrijvers

Bibliothecarissen

Kunstenaars

Hogere beroepen m.b.t. gedrag en maatschappij e.d.

Geestelijk verzorgers

Journalisten

Sociaal-cultureel werkers

Sociaal-wetenschappelijk medewerkers

Hogere verzorgende beroepen

Afdelingshoofden zorginstelling

Managers ( $\mathrm{HBO}$ werk- en denkniveau)

3.000

Leidinggevenden

3.000

laag

2.500

5.000

13.000

4.500

2.500

8.500

7.000

-

4.000

\section{Wetenschappelijke pedagogische beroepen}

\section{gemiddeld gemiddeld laag laag - zeer laag}

sterk stijgend -

Docenten exacte, medische verzorgende vakken ( 1 "gr.)

Docenten landbouw en techniek ( $1^{\circ} \mathrm{gr}$ )

Docenten economische-administratieve

vakken ("gr.)

Docenten letteren

Docenten sociale vakken

Docent $1^{\theta} \mathrm{gr}$. zonder specialisatie

Onderwijskundigen en pedagogen

Wetenschappelijke landbouwkundige beroepen

Landbouwkundigen 
Wetenschappelijke wiskundige, natuurwetenschappelijke beroepen

Natuurwetenschappers

Wetenschappelijke technische beroepen

Werktuigbouwkundigen

(Weg-en water)bouwkundigen

Electrotechnici

Materiaalkundigen

Wetenschappelijke (para)medische beroepen e.d.

4.000

Artsen

Apothekers

3.500

laag

sterk dalend

Wetenschappelijke economische, administratieve beroepen e.d.

5.000

Economen

Organisatiedeskundigen

Accountants

Informatici

Wetenschappelijke juridische, bestuurlijke beroepen

Juristen

3.000

zeer laag

stijgend

Wetenschappelijke beroepen m.b.t. gedrag en maatschappij

Geestelijken

Taalkundigen

Sociale raadslieden en hoofden

personeelszaken

Sociaal-wetenschappelijk onderzoekers

Managers (wetenschappelijk werk-en denkniveau)

Managers 


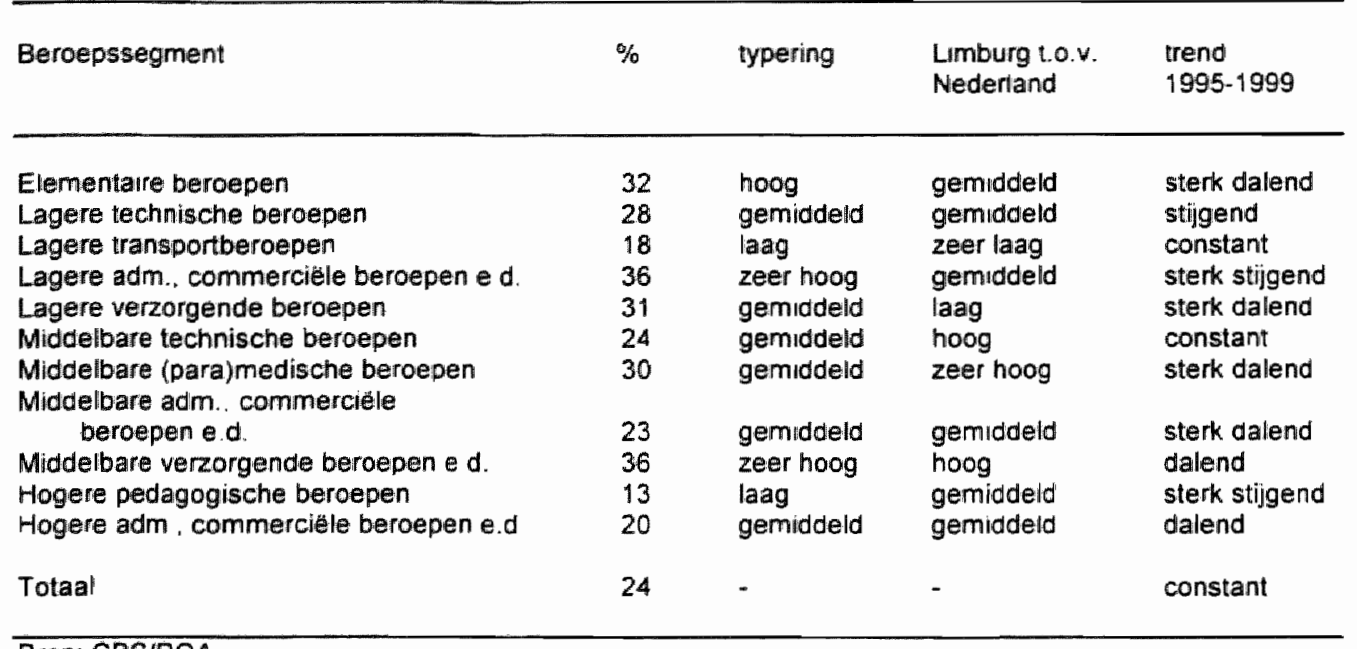

Bron: CBS/ROA 
Tabel 111

Percentage ouderen (50-64 jaar) per beroepssegment, Limburg. gemiddelde 1998-1999

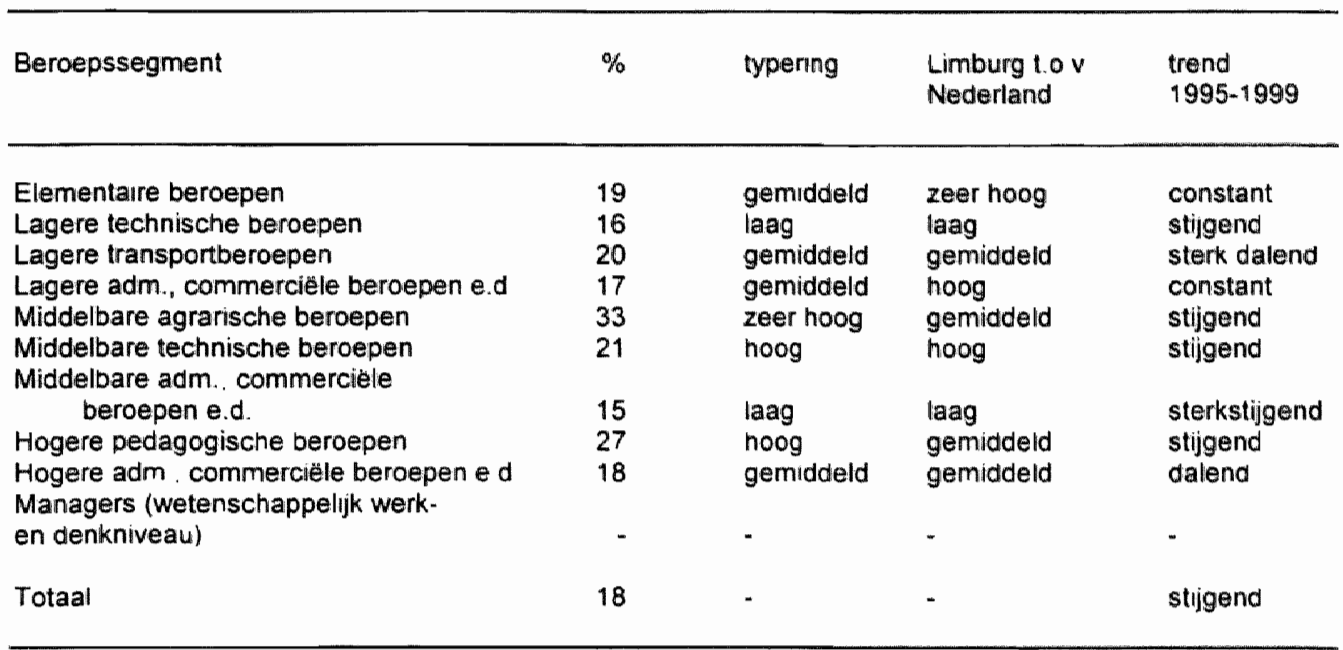

Bron: CBS/ROA 
Tabel 1.12

Percentage vrouwen per beroepssegment. Limburg. gemiddelde 1998-1999

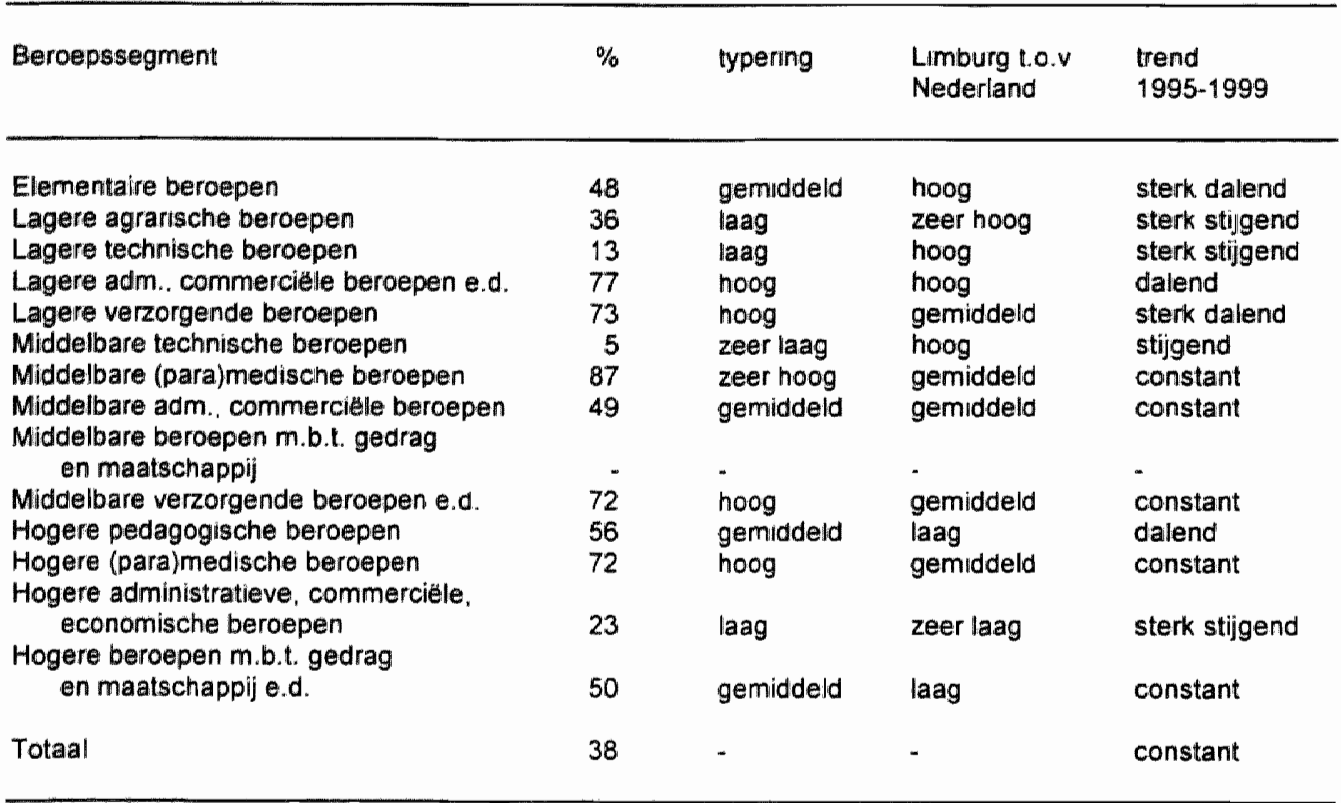

Bron: CBS/ROA 
Tabel 1.13

Percentage flexibel werk per beroepssegment. Limburg. gemiddelde 1998-1999

\begin{tabular}{|c|c|c|c|c|}
\hline Beroepssegment & $\%$ & typering & $\begin{array}{l}\text { Limburg t.o.v. } \\
\text { Nederland }\end{array}$ & $\begin{array}{l}\text { trend } \\
1995-1999\end{array}$ \\
\hline Elementaire beroepen & 22 & zeer hoog & gemiddeld & dalend \\
\hline Lagere technische beroepen & 10 & laag & hoog & constant \\
\hline Lagere transportberoepen & 14 & gemiddeld: & zeer hoog & sterk dalend \\
\hline Lagere adm., commerciële beroepen e.d. & 16 & gemiddeld & gemiddeld & sterk stijgend \\
\hline Lagere verzorgende beroepen & 19 & hoog & laag & sterk dalend \\
\hline Middelbare technische beroepen & - & - & - & . \\
\hline Middelbare adm. commerciële beroepen & 6 & zeer laag & laag & sterk stijgend \\
\hline Totaal & 9 & - & - & constant \\
\hline
\end{tabular}

\section{Bron: CBS/ROA}

Van flexibel werk is sprake bij uitzendkrachten, oproepkrachten, invalkrachten, contracten zonder een vast aantal arbeidsuren en indien geen vast dienstverband is overeengekomen. 
Tabel 1.14

Percentage deeltujdwerk (12 tot 32 uur) per beroepssegment. Limburg, gemiddelde 1998-1999

Beroepssegment

$\%$

$\% \quad$ typering

Limburg t.o v.

Nederland

trend

$1995-1999$

\section{Elementaire beroepen}

Lagere technische beroepen

Lagere transportberoepen

Lagere adm. commerciêle beroepen ed.

Lagere verzorgende beroepen

Middelbare technische beroepen

Middelbare (para)medische beroepen

Middelbare adm., commerciẻle beroepen

Middelbare verzorgende beroepen e.d.

Hogere pedagogische beroepen

Hogere (para)medische beroepen

Hogere administratieve, commercièle.

economische beroepen e.d.

Hogere beroepen mbt gedrag en

Maatschappij

Totaal

Bron: CBS/ROA

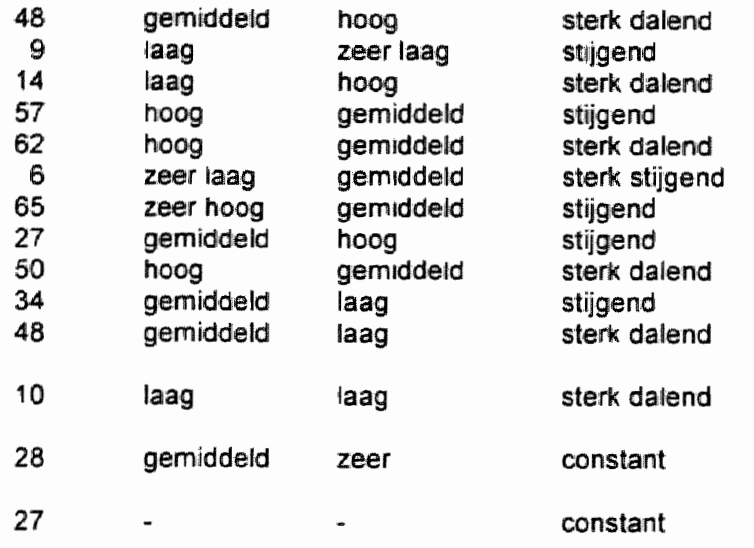

27 
Tabel 115

Percentage zelfstandigen per bercepssegment, Limburg. gemiddelde 1998-1999

\begin{tabular}{|c|c|c|c|c|}
\hline Beroepssegment & $\%$ & typering & $\begin{array}{l}\text { Limburg 1.0.V } \\
\text { Nederland }\end{array}$ & $\begin{array}{l}\text { trend } \\
1995-1999\end{array}$ \\
\hline $\begin{array}{l}\text { Lagere technische beroepen } \\
\text { Lagere verzorgende beroepen } \\
\text { Middelbare agrarische beroepen } \\
\text { Middelbare technische beroepen } \\
\text { Middelbare adm., commerciële beroepen } \\
\text { Middelbare verzorgende beroepen e.d. } \\
\text { Hogere administratieve. commerciële. } \\
\text { economische beroepen e.d }\end{array}$ & $\begin{array}{r}6 \\
22 \\
90 \\
10 \\
11 \\
24 \\
20\end{array}$ & $\begin{array}{l}\text { zeer laag } \\
\text { gemiddeld } \\
\text { zeer hoog } \\
\text { laag } \\
\text { gemiddeld } \\
\text { hoog } \\
\text { gemiddeld }\end{array}$ & $\begin{array}{l}\text { laag } \\
\text { zeer hoog } \\
\text { gemiddeld } \\
\text { laag } \\
\text { hoog } \\
\text { gemiddeld } \\
\text { gemiddeld }\end{array}$ & $\begin{array}{l}\text { sterk dalend } \\
\text { sterk stijgend } \\
\text { constant } \\
\text { sterk stijgend } \\
\text { sterk dalend } \\
\text { sterk stijgend } \\
\text { constant }\end{array}$ \\
\hline Totaal & 11 & - & - & constant \\
\hline
\end{tabular}

Bron: CBS/ROA 


$$
\text { Opleidingstype }
$$

aantal

Basisonderwijs

VMBO Theorie

VMO theorie

VMBO Landbouw en natuurlike omgeving

VMBO landbouw en natuurlijke omgeving

\section{VMBO Techniek}

VMBO bouwtechniek

VMBO installatietechniek

VMBO mechanische techniek

VMBO fljnmechanische techniek

VMBO voertuigentechniek

VMBO elektrotechniek

VMBO grafische techniek

VMBO brood en banket

VMBO transport en logistiek

VMBO techniek overig

\section{VMBO Economie}

VMBO administratie, handel en mode VMBO consumptief en levensmiddelentech.

VMBO Zorg en welzijn

VMBO (uiterlijke) verzorging

VMBO Beveiliging

VMBO bevelliging

VMBO Overig

VMBO overig

HAVONWO

HAVOMNO

MBO Landbouw en natuurijke omgeving

MBO landbouw en veeteelt

MBO milies en groene ruimte

MBO Techniek

MBO laboratorium

MBO bouw

$M B O$ grond-, weg-en waterbouw

MBO installatietechniek

MBO werktuigbouw en mechanische techn.

MBO fijnmechanische techniek

MBO motorvoertuigentechniek

MBO vliegtuigtechniek
39.500

39.500

gemiddeld

constant

30.000

22.000

Limburg t.o.v. trend

Nederland $\quad$ 1997-1999

30.000

gemiddeld

constant

3.500

2.500

laag

dalend

42.000

11.000

12.000

3.000

4.000

3.000

6.500

10.000

8.500

gemiddeld

dalend

15.000

15.000

hoog

sterk dalend

22.000

laag

constant

9.000

8.000

hoog

stijgend

61.000

8.500

laag

constant

-

dalend

11.500

hoog

hoog

sterk dalend 
aantal

Limburg t.o.v. trend

Nederland

MBO operationele techniek

MBO elektrotechniek

MBO grafische techniek

MBO procestechniek

MBO brood en banket

MBO levensmiddelentechniek/vleesverw.

$M B O$ vervoer vervoer en logistiek

MBO techniek overig

MBO Dienstverlening en gezondheidszorg

MBO dokters-, tandarts- en dierenassistent

MBO apothekersassistent

$M B O$ verpleging

MBO gezondheidstechniek

MBO sociaal-cultureel

MBO verzorging

MBO uiterlijke verzorging

MBO horeca

MBO beweging en therapie

MBO Economie

MBO administratie

MBO handel

MBO secretariaat

MBO toerisme en recreatie

MBO bedrijfskunde

MBO automatisering

MBO geld, bank en belastingen

$M B O$ verzekeringswezen

MBO Openbare orde en veiligheid

MBO openbare orde en veiligheid

\section{MBO Overig}

MBO overig

HBO Onderwijs en tolk en vertaler

HBO lerarenopleiding basisonderwijs

HBO lerarenopleiding tallen

$\mathrm{HBO}$ lerarenopleiding natuur en techniek

HBO lerarenopleiding economie en maatsch.

HBO lerarenopleiding lichamelijke opvoeding

$\mathrm{HBO}$ lerarenopleiding medisch en verzorging

HBO lerarenopleiding expressie

\section{HBO Landbouw}

HBO landbouw en veeteelt

$\mathrm{HBO}$ milieukunde en levensmiddelentechnologie
12.500

2.500

5.500

gemiddelo

laag

zeer hoog

$-$

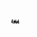

zeer hoog

4.500

51.000

9.500

4.500

18.500

5.500

6.500

2.500

59.500

22.500

18.000

8.000

2.500

2.500

6.500

6.500

gemiddeld

dalend

gemiddeld

laag

gemiddeld

laag

laag

$-$

hoog

hoog

gemiddeld

hoog

dalend

stijgend

sterk stijgend

-

stijgend

dalend

constant

constant

sterk stijgend

constant

constant

dalend

constant

sterk stijgend

sterk dalend

dalend

-

23.500

13.500

3.000

2.500

gemiddeld

hoog

gemiddeld sterk stijgend

sterk stijgend sterk stijgend 
Tabel 1.16 (vervolg)

Aantal werkenden per opleidingstype, Limburg. gemiddelde 1998-1999

Opleidingstype

aantal

Limburg t.o.v.

trend

Nederland

1997-1999

HBO Techniek

HBO laboratorium

HBO bouwkunde

HBO civiele techniek

HBO werktuigbouwkunde

$\mathrm{HBO}$ elektrotechniek

$\mathrm{HBO}$ informatica

$\mathrm{HBO}$ chemische technologie

HBO vervoer en logistiek

HBO Paramedisch

$\mathrm{HBO}$ verpleegkunde

$\mathrm{HBO}$ (fysio)therapie

$\mathrm{HBO}$ voeding

$\mathrm{HBO}$ radiologie

HBO paramedisch overig

HBO Economie

HBO accountancy en bedriffseconomie

$\mathrm{HBO}$ commerciële economie

$\mathrm{HBO}$ toerisme en recreatie

$\mathrm{HBO}$ recht en bestuur

HBO secretariaat

$\mathrm{HBO}$ bedrijfskunde

HBO Sociaal-cultureel

HBO communicatie en journalistiek

HBO maatschappelijk werk en hulpverlening

HBO personeel en arbeid

$\mathrm{HBO}$ bibliotheek en documentatie

HBO sociaal-cultureel overig

HBO Kunst

$\mathrm{HBO}$ uitvoerende en beeldende kunsten

HBO Openbare orde en velligheid

HBO openbare orde en veiligheid

HBO Overig

HBO overig

WO Letteren en theologie

WO letteren

WO Theologie
16.000

$\begin{array}{rll}2.500 & \text { laag } & \text { sterk dalend } \\ - & - & - \\ 3.000 & - & - \\ 3.000 & \text { gemiddeld } & \text { dalend } \\ 3.000 & \text { gemiddeld } & \text { sterk stijgend } \\ - & \text { gemiddeld } & \text { constant } \\ - & - & -\end{array}$

10.000

4.000

3.500

gemiddeld

hoog

sterk stijgend sterk stijgend

-

-

16.000

4.500

laag

constant

3.000

laag

constant

5.000

-

gemiddeld

stijgend

10.500

6.000

gemiddeld

sterk stijgend

-

4.000

$4.000 \quad$ hoog

sterk stijgend

2.500

2.500

gemiddeld

stijgend 


\section{Wo Techniek}

WO landbouw en milieukunde

WO wiskunde en natuurwetenschappen

WO bouwkunde

WO civiele techniek

WO werktuigbouwkunde

WO elektrotechniek

WO informatica en bestuurlijke informatiekunde

WO Medisch

WO (dier)geneeskunde

WO tandheelkunde

WO farmacie

WO Economie

WO econom(etr)ie

WO bedrïfskunde

WO accountancy en belastingen

wo rechten en bestuurskunde

WO Sociaal-cultureel

WO sociale wetenschappen

WO sociaal-cultureel overig

\section{WO Kunst}

WO kunstwetenschappen

Wo Overig

WO overig

Totaal
6.500

3.500

zeer laag

constant

$-$

$-$

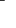

3.500

2.500

laag

sterk dalend

$*$

-

$+$

8.000

$\begin{array}{rll}2.500 & \text { zeer laag } & \text { dalend } \\ - & - & - \\ 3.000^{-} & - & - \\ & \text {zeer laag } & \text { stiggend }\end{array}$

4.500

3.500

zeer laag

constant

2.500

zeer hoog

sterk stijgend

466.500 


\section{$\%$ werkzaam $\%$ werkloos}

$\%$ nietparticiperend totaal
BASISONDERWIJS

Basisonderwijs

Basisonderwijs

VMBO

VMBO theorie

VMBO Landbouw en natuurlijke omgeving

VMBO landbouw en natuurlijke omgeving

VMBO Techniek

VMBO bouwtechniek

VMBO mechanische techniek

VMBO voertuigentechniek

VMBO elektrotechniek

VMBO transport en logistiek

VMBO techniek overig

VMBO Economie

VMBO administratie, handel en mode

VMBO Verzorging

VMBO (uiterlijke) verzorging

HAVONMN, MBO

HAVOIVWO

HAVOMWO

MBO Landbouw en natuurlijke omgeving

$M B O$ landbouw en veeteelt

MBO Techniek

MBO bouw

MBO werktuigbouw en mechanische techniek

MBO motorvoertuigentechniek

MBO elektrotechniek

MBO procestechniek

MBO techniek overig

MBO Dienstvertening en gezondheidszorg

$M B O$ verpleging

MBO sociaal-cultureel

$M B O$ verzorging

$M B O$ uiterlijke verzorging

MBO horeca

$\mathrm{MBO}$ beweging en therapie

MBO Economie

MBO administratie

MBO handel

MBO secretariaat

MBO bedrijfskunde

MBO automatisering
49

39

49

47

30

70

4

4

4

4

$57 \quad 76.000$

70

80

7

37

3

89

60

7

(1)

0

3

66

302.500

$47 \quad 44.500$

8

9.000

10.500

14.500

6.000

14.500

5.500

6.000

$29 \quad 14.000$

7.000
$-\quad 31.000$

$37 \quad 31.000$

$37 \quad 10.000$

$28 \quad 10.000$

28.000
$-\quad 3.500$

78

66

75

90 
Tabel 1.17 (vervolg)

Arbeidsmarktpositie potentiële beroepsbevolking naar opleidingstype, Limburg, gemiddelde 1998-1999

Opleidingstype

$\%$ werkzaam $\%$ werkloos

$\%$ niet-

totaal

participerend

MBO Openbare orde en veiligheid

MBO openbare orde en veiligheid

84

78

75

90

HBO lerarenopl. natuur en techniek

HBO Techniek

HBO laboratorium

HBO werktuigbouwkunde

HBO electrotechniek

$\mathrm{HBO}$ informatica

HBO Paramedisch

HBO verpleegkunde

HBO (fysio)therapie

HBO Economie

HBO accountancy en bedrijfseconomie

HBO commerciële economie

HBO recht en bestuur

$\mathrm{HBO}$ bedrijfskunde

HBO Sociaal-cultureel

HBO maatschappelijk werk en hulpverlening

HBO Kunst

HBO uitvoerende en beeldende kunsten

wo

WO Techniek

WO wiskunde en natuurwetenschappen

WO Medisch

WO (dier)geneeskunde

WO Economie

WO econom(etr)ie

WO rechten en bestuurskunde

WO Sociaal-cultureel

WO sociale wetenschappen

Totaal

85

88

95

84

83

74

92

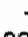

82

83

84

90

94

94

95

86

61
8.000

3

$19 \quad 104.500$

$22 \quad 18.000$

-
$-\quad 3000$

5.000

- 4.500

6.000

-
$-\quad 3.000$
$-\quad 300$

- $\quad 3.000$

- 6.000

- $\quad 7.500$

- $\quad 4.500$

$8 \quad 33.000$

4.000

3.000

3.000

4.000

3

36

Bron CBS/ROA 
Tabel 1.18

Percentage jongeren (15-29 jaar) per opleidingssector. Limburg. gemiddelde 1998-1999

\begin{tabular}{|c|c|c|c|c|}
\hline Opleidingssector & $\%$ & typerng & $\begin{array}{l}\text { Limburg t.o } \mathrm{v} \\
\text { Nederland }\end{array}$ & $\begin{array}{l}\text { trend } \\
1997-1999\end{array}$ \\
\hline $\begin{array}{l}\text { Basisonderwijs } \\
\text { VMBO Theorie } \\
\text { VMBO Techniek } \\
\text { VMBO Economie } \\
\text { VMBO Zorg en weizijn } \\
\text { HAVONWO } \\
\text { MBO Landbouw en natuurlijke omgeving } \\
\text { MBO Techniek } \\
\text { MBO Dienstwerlening en gezondheidszorg } \\
\text { MBO Economie } \\
\text { HBO Onderwijs en tolk en vertaler } \\
\text { HBO Techniek } \\
\text { HBO Paramedisch } \\
\text { HBO Economie }\end{array}$ & $\begin{array}{l}18 \\
28 \\
24 \\
28 \\
18 \\
32 \\
26 \\
24 \\
34 \\
28 \\
11 \\
20 \\
23 \\
32\end{array}$ & $\begin{array}{l}\text { laag } \\
\text { hoog } \\
\text { gemiddeld } \\
\text { gemiddeld } \\
\text { laag } \\
\text { hoog } \\
\text { gemiddeld } \\
\text { gemiddeld } \\
\text { zeer hoog } \\
\text { gemiddeld } \\
\text { zeer lalag } \\
\text { laag } \\
\text { gemiddeld } \\
\text { hoog }\end{array}$ & $\begin{array}{l}\text { gemiddeld } \\
\text { laag } \\
\text { gemiddeld } \\
\text { laag } \\
\text { gemiddeld } \\
\text { laag } \\
\text { gemiddeld } \\
\text { gemiddeld } \\
\text { zeer hoog } \\
\text { hoog } \\
\text { laag } \\
\text { gemiddeld } \\
\text { hoog } \\
\text { hoog }\end{array}$ & $\begin{array}{l}\text { sterk dalend } \\
\text { constant } \\
\text { stijgend } \\
\text { constant } \\
\text { sterk dalend } \\
\text { dalend } \\
\text { sterk dalend } \\
\text { constant } \\
\text { sterk dalend } \\
\text { dalend } \\
\text { constant } \\
\text { sterk stijgend } \\
\text { sterk stijgend } \\
\text { constant }\end{array}$ \\
\hline Totaal & 24 & - & - & constant \\
\hline
\end{tabular}

Bron: CBS/ROA 
Tabel 1.19

Percentage ouderen (50-64) per opleidingssector. Limburg. gemiddelde 1998-1999

\begin{tabular}{|c|c|c|c|c|}
\hline Opleidingssector & $\%$ & typering & $\begin{array}{l}\text { Limburg t.o.w. } \\
\text { Nederland }\end{array}$ & $\begin{array}{l}\text { trend } \\
1997-1999\end{array}$ \\
\hline $\begin{array}{l}\text { Basisonderwijs } \\
\text { VMBO Theorie } \\
\text { VMBO Techniek } \\
\text { VMBO Zorg en welzijn } \\
\text { MBO Techniek } \\
\text { MBO Dienstverlening en gezondheidszorg } \\
\text { MBO Economie } \\
\text { HBO Onderwijs en tolk en vertaler } \\
\text { HBO Techniek }\end{array}$ & $\begin{array}{r}26 \\
22 \\
20 \\
24 \\
20 \\
8 \\
15 \\
27 \\
21\end{array}$ & $\begin{array}{l}\text { hoog } \\
\text { gemiddeld } \\
\text { gemiddeld } \\
\text { hoog } \\
\text { gemiddeld } \\
\text { laag } \\
\text { gemiddeld } \\
\text { zeer hoog } \\
\text { gemidideld }\end{array}$ & $\begin{array}{l}\text { gemiddeld } \\
\text { hoog } \\
\text { zeer hoog } \\
\text { gerniddeld } \\
\text { hoog } \\
\text { laag } \\
\text { laag } \\
\text { gemiddeld } \\
\text { gemiddeld }\end{array}$ & $\begin{array}{l}\text { stijgend } \\
\text { constant } \\
\text { sterk stijgend } \\
\text { stenk stijgend } \\
\text { sterk stijgend } \\
\text { constant } \\
\text { sterk stijgend } \\
\text { dalend } \\
\text { constant }\end{array}$ \\
\hline Totaal & 18 & . & - & stijgend \\
\hline
\end{tabular}

Bron: CBS/ROA 
Tabel 1.20

Percentage vrouwen per opleidingssector. Limburg. gerniddelde 1998-1999

\begin{tabular}{|c|c|c|c|c|}
\hline Opleidingssector & $\%$ & typering & $\begin{array}{l}\text { Limburg t.o v } \\
\text { Nederiand }\end{array}$ & $\begin{array}{l}\text { trend } \\
1997-1999\end{array}$ \\
\hline $\begin{array}{l}\text { Basisonderwijs } \\
\text { VMBO Theorie } \\
\text { VMBO Economie } \\
\text { VMBO Zorg en welzijn } \\
\text { HAVONWO } \\
\text { MBO Techniek } \\
\text { MBO Dienstverlening en gezond heidszorg } \\
\text { MBO Economie } \\
\text { HBO Onderwijs en tolk en vertaler } \\
\text { HBO Paramedisch } \\
\text { HBO Economie } \\
\text { HBO Sociaal-cultureel }\end{array}$ & $\begin{array}{r}30 \\
48 \\
49 \\
95 \\
46 \\
4 \\
84 \\
50 \\
56 \\
69 \\
33 \\
52\end{array}$ & $\begin{array}{l}\text { laag } \\
\text { gemiddeld } \\
\text { gemiddeld } \\
\text { zeer hoog } \\
\text { gemiddeld } \\
\text { zeer laag } \\
\text { hoog } \\
\text { gemiddeld } \\
\text { gemiddeld } \\
\text { hoog } \\
\text { laag } \\
\text { gemiddeld }\end{array}$ & $\begin{array}{l}\text { gemiddeld } \\
\text { gemiddeld } \\
\text { gemiddeld } \\
\text { gemiddeld } \\
\text { hoog } \\
\text { laag } \\
\text { zeer hoog } \\
\text { zeer hoog } \\
\text { gemiddeld } \\
\text { gemiddeld } \\
\text { laag } \\
\text { zeer laag }\end{array}$ & $\begin{array}{l}\text { constant } \\
\text { constant } \\
\text { sterk dalend } \\
\text { dalend } \\
\text { dalend } \\
\text { sterk dalend } \\
\text { stijgend } \\
\text { stigend } \\
\text { constant } \\
\text { stijgend } \\
\text { dalend } \\
\text { stijgend }\end{array}$ \\
\hline Totaal & 38 & - & - & constant \\
\hline
\end{tabular}

Bron: CBS/ROA 
Tabel 1.21

Percentage flexibel werk per opleidingssector, Límburg. gemiddelde 1998-1999

\begin{tabular}{lrlll}
\hline Opleidingssector & $\%$ & typering & $\begin{array}{l}\text { Limburg t.o.v. } \\
\text { Nederland }\end{array}$ & $\begin{array}{c}\text { trend } \\
1997-1999\end{array}$ \\
& & & & \\
& & & & \\
Basisondewijs & 13 & gemiddeld & gemiddeld & stijgend \\
VMBO Theorie & 18 & hoog & hoog & sterk stijgend \\
VMBO Techniek & 6 & gemiddeld & laag & sterk stijgend \\
VMBO Zorg en welzijn & 21 & zeer hoog & zeer hoog & sterk stijgend \\
HAVOMWO & 18 & hoog & gemiddeld & sterk stijgend \\
MBO Techniek & 5 & laag & gemiddeld & stijgend \\
MBO Dienstverlening en gezondheidszorg & 10 & gemiddeld & gemiddeld & sterk stijgend \\
MBO Economie & 6 & laag & laag & sterk dalend \\
Totaal & & & & -
\end{tabular}

\section{Bron: CBS/ROA}

Van flexibel werk is sprake bij uitzendkrachten, oproepkrachten, invalkrachten, contracten zonder een vast aantal arbeidsuren en indien geen vast dienstverband is overeengekomen. 
Tabel 1.22

Percentage deeltijdwerk (12 vot 32 uur) per oplendingssector, Limburg, gemiddelde 1998-1999

\begin{tabular}{|c|c|c|c|c|}
\hline Opleidingssector & $\%$ & typering & $\begin{array}{l}\text { Limburg t.ov. } \\
\text { Nederland }\end{array}$ & $\begin{array}{l}\text { trend } \\
1997-1999\end{array}$ \\
\hline $\begin{array}{l}\text { Basisonderwijs } \\
\text { VMBO Theorie } \\
\text { VMBO Techniek } \\
\text { VMBO Economie } \\
\text { VMBO Zorg en welzijn } \\
\text { HAVONMO } \\
\text { MBO Techniek } \\
\text { MBO Dienstverlening en gezondheidszorg } \\
\text { MBO Economie } \\
\text { HBO Onderwijs en tolk en vertaler } \\
\text { HBO Paramedisch } \\
\text { HBO Economie } \\
\text { HBO Sociaal-cultureel }\end{array}$ & $\begin{array}{r}28 \\
39 \\
8 \\
34 \\
73 \\
41 \\
6 \\
57 \\
28 \\
36 \\
42 \\
15 \\
31\end{array}$ & $\begin{array}{l}\text { laag } \\
\text { gemiddeld } \\
\text { laag } \\
\text { gemiddeld } \\
\text { zeer hoog } \\
\text { hoog } \\
\text { zeer laag } \\
\text { hoog } \\
\text { gemiddeld } \\
\text { gemiddeld } \\
\text { hoog } \\
\text { laag } \\
\text { gemiddeld }\end{array}$ & $\begin{array}{l}\text { hoog } \\
\text { gemiddeld } \\
\text { gemiddeld } \\
\text { laag } \\
\text { hoog } \\
\text { zeer hoog } \\
\text { gemiddeld } \\
\text { gemiddeld } \\
\text { hoog } \\
\text { gemiddeld } \\
\text { laag } \\
\text { laag } \\
\text { zeer laag }\end{array}$ & $\begin{array}{l}\text { constant } \\
\text { stijgend } \\
\text { stijgend } \\
\text { sterk dalend } \\
\text { constant } \\
\text { constant } \\
\text { sterk dalend } \\
\text { constant } \\
\text { stijgend } \\
\text { constant } \\
\text { dalend } \\
\text { dalend } \\
\text { constant dalend }\end{array}$ \\
\hline Totaal & 27 & - & - & constant \\
\hline
\end{tabular}

Bron: CBS/ROA 
Tabel 1.23

Percentage zelfstandigen per opleidingssector, Limburg, gemiddelde 1998-1999

\begin{tabular}{|c|c|c|c|c|}
\hline Opleidingssector & $\%$ & typering & $\begin{array}{l}\text { Limburg t.o.v. } \\
\text { Nederland }\end{array}$ & $\begin{array}{l}\text { trend } \\
1997-1999\end{array}$ \\
\hline $\begin{array}{l}\text { Basisonderwijs } \\
\text { VMBO Theorie } \\
\text { VMBO Techniek } \\
\text { MBO Landbouw en natuurlijke omgeving } \\
\text { MBO Techniek } \\
\text { MBO Dienstverlening } \\
\text { MBO Economie }\end{array}$ & $\begin{array}{r}9 \\
9 \\
7 \\
48 \\
9 \\
12 \\
13\end{array}$ & $\begin{array}{l}\text { gemiddeld } \\
\text { gemiddeld } \\
\text { laag } \\
\text { zeer hoog } \\
\text { laag } \\
\text { gemiddeld } \\
\text { hoog }\end{array}$ & $\begin{array}{l}\text { gemiddeld } \\
\text { gemiddeld } \\
\text { laag } \\
\text { hoog } \\
\text { laag } \\
\text { zeer hoog } \\
\text { gemiddeld }\end{array}$ & $\begin{array}{l}\text { stijgend } \\
\text { dalend } \\
\text { constant } \\
\text { sterk stijgend } \\
\text { constant } \\
\text { sterk stijgend } \\
\text { stijgend }\end{array}$ \\
\hline Totaal & 11 & - & - & constant \\
\hline
\end{tabular}

Bron: CBS/ROA 


\section{Actuele discrepanties op de Limburgse arbeidsmarkt}




\section{(20.0.}

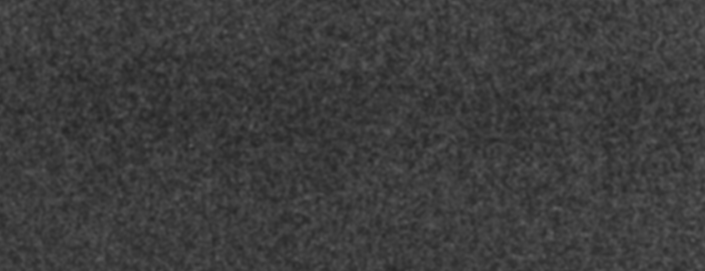

W.

3.4.

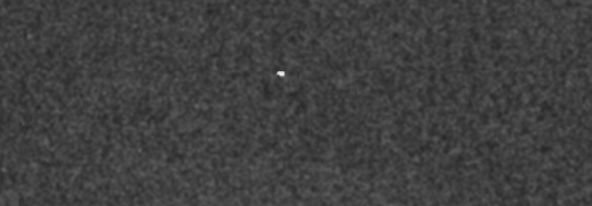

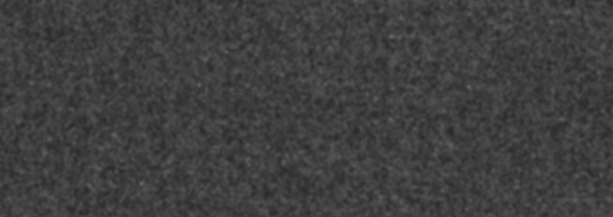

W.

4.

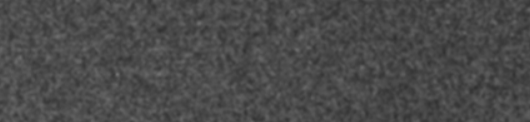

10.0.

W.

incosis

1.5.

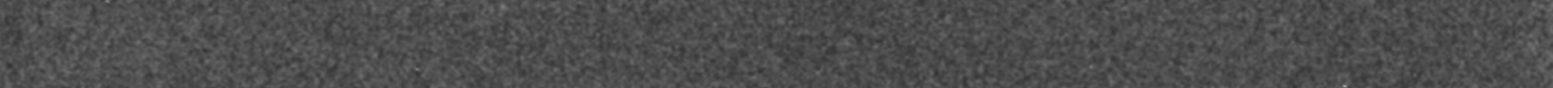
Q

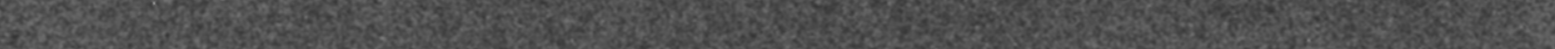

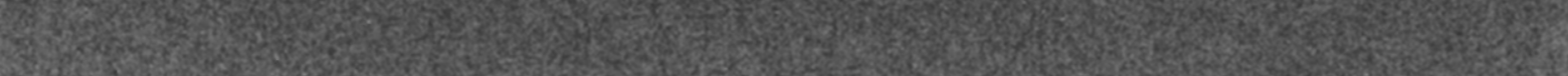

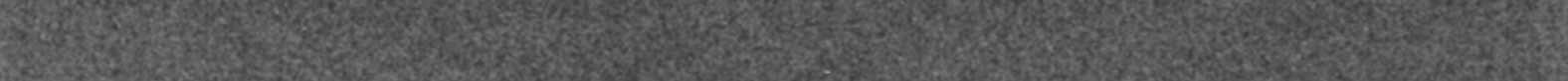

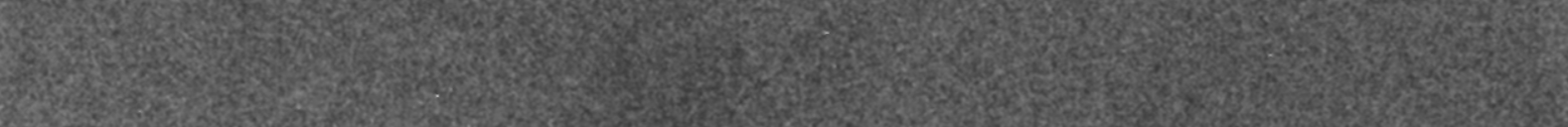


Tabel 2.1

Openstaande vacatures per bedrijfssector, Limburg, april 2000

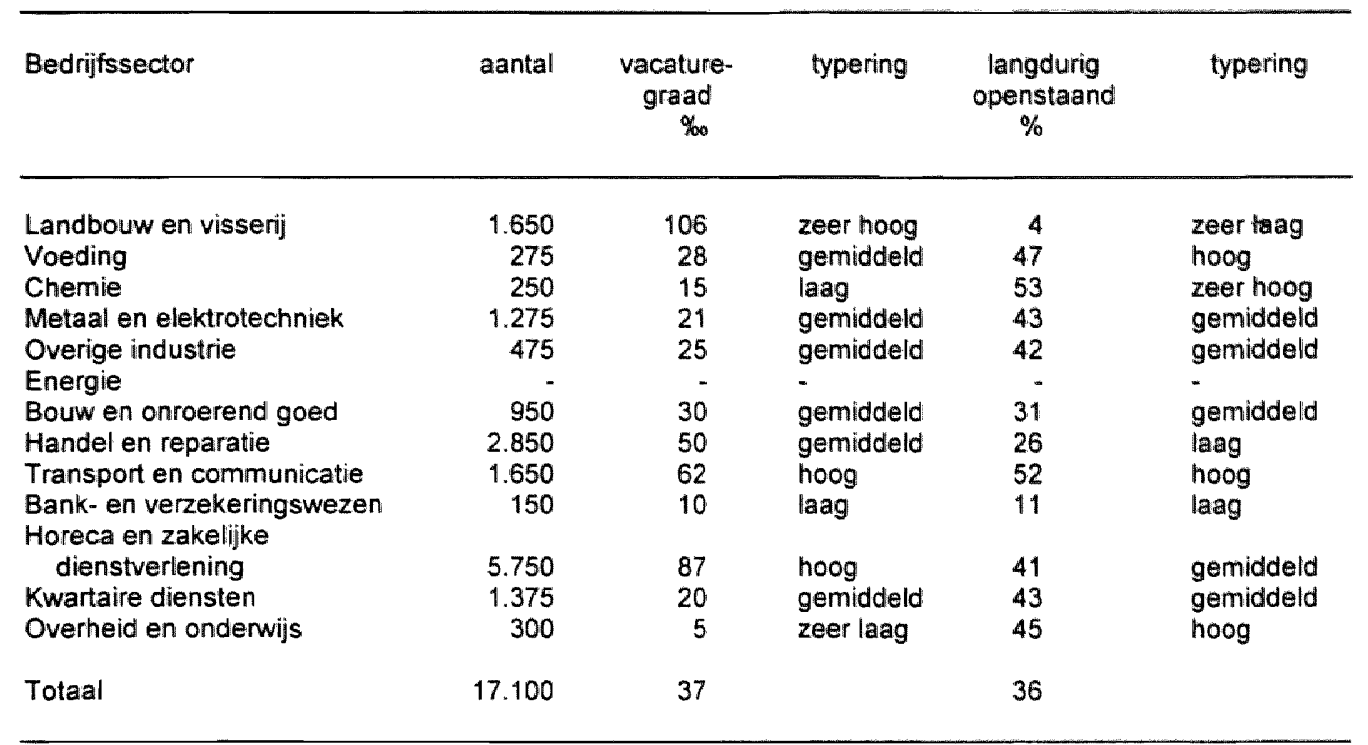

Bron: Arbeidsvoorziening/CBS/ROA 


\begin{tabular}{|c|c|c|c|c|}
\hline Beroepssegment & aantal & $\begin{array}{c}\text { vacature- } \\
\text { graad } \\
\% \text { ho }\end{array}$ & typering & $\begin{array}{c}\% \text { langdurig } \\
\text { openstaand } \\
\%\end{array}$ \\
\hline
\end{tabular}

\begin{tabular}{|c|c|c|c|c|c|}
\hline Elementaire beroepen & 3700 & 110 & hoog & 30 & gemiddeld \\
\hline Lagere niel-specialistische beroepen & * & - & - & - & $\cdot$ \\
\hline Lagere docenten sportvakken & - & - & - & $=$ & - \\
\hline Lagere agrarische beroepen & 100 & 17 & laag & 10 & zeer laag \\
\hline Lagere wiskundige, natuurwet beroepen & - & - & - & $=$ & - \\
\hline Lagere technische beroepen & 2.125 & 49 & hoog & 43 & hoog \\
\hline Lagere transportberoepen & 575 & 29 & gemiddeld & 34 & gemiddeld \\
\hline $\begin{array}{l}\text { Lagere (para)medische beroepen } \\
\text { Lagere administratieve. commerciele }\end{array}$ & 200 & - & $=$ & 69 & zeer hoog \\
\hline beroepen & 2.050 & 58 & hoog & 32 & gemiddeld \\
\hline Lagere beveiligingsberoepen & 250 & $\cdot$ & - & 57 & zeer hoog \\
\hline Lagere verzorgende beroepen & 2025 & 150 & zeer hoog & 36 & noog \\
\hline $\begin{array}{l}\text { Middelbare docenten transport: } \\
\text { sportvakken }\end{array}$ & - & - & - & - & - \\
\hline $\begin{array}{l}\text { Middelbare agrarische beroepen } \\
\text { Middelbare wiskundige, natuurwet. }\end{array}$ & 125 & 19 & gemiddeld & 31 & gemiddeld \\
\hline beroepen & - & - & - & - & - \\
\hline Middebare technische beroepen & 1.200 & 21 & gemiddeld & 47 & hoog \\
\hline Middelbare transportberoepen e.d. & 100 & 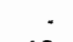 & - & 35 & hoog \\
\hline $\begin{array}{l}\text { Middelbare (para)medische beroepen } \\
\text { Middelbare administratıeve, commerclële }\end{array}$ & 275 & 16 & laag & 49 & hoog \\
\hline $\begin{array}{l}\text { beroepen e.d. } \\
\text { Middelbare juridische, bestuurlijke. }\end{array}$ & 1.300 & 21 & gemiddeld & 34 & gemiddeld \\
\hline $\begin{array}{l}\text { beveiligingsberoepen } \\
\text { Middelbare taalkundige. culturele }\end{array}$ & - & - & - & - & - \\
\hline $\begin{array}{l}\text { beroepen } \\
\text { Middelbare beroepen m.b.l. gedrag en }\end{array}$ & - & - & - & - & - \\
\hline maatschappij & 100 & - & - & - & - \\
\hline Middelbare verzorgende beroepen e.d & 500 & 28 & gemiddeld & 30 & gemiddeld \\
\hline Hogere pedagogische beroepen & 600 & 34 & gemiddeld & 30 & gemiddeld \\
\hline $\begin{array}{l}\text { Hogere landbouwkundige beroepen } \\
\text { Hogere wiskundige. }\end{array}$ & - & - & - & - & - \\
\hline natuurwetenschappelijke beroepen & - & - & - & - & - \\
\hline Hogere technische beroepen & 125 & 18 & laag & 50 & hoog \\
\hline Hogere transportberoepen & - & $=$ & $\cdot$ & - & - \\
\hline $\begin{array}{l}\text { Hogere (para)medische beroepen } \\
\text { Hogere administratieve. commerciele. }\end{array}$ & 100 & 10 & zeer laag & 37 & hoog \\
\hline $\begin{array}{l}\text { economische beroepen } \\
\text { Hogere juridische. bestuurlijke, }\end{array}$ & 550 & 19 & gemiddeld & 21 & laag \\
\hline beveiligingsberoepen & - & - & - & - & - \\
\hline $\begin{array}{l}\text { Hogere taalkundige. eulturele beroepen } \\
\text { Hogere beroepen m b.t. gedrag en }\end{array}$ & 25 & - & - & - & - \\
\hline maatschappij & 500 & 59 & hoog & 21 & laag \\
\hline Hogere verzorgende beroepen & - & - & - & - & - \\
\hline Managers ( $\mathrm{HBO}$ werk- en denkniveau) e.d. & 200 & - & - & 27 & - \\
\hline Totaal & 7.100 & 37 & & 36 & \\
\hline
\end{tabular}

Bron: Arbeidsvoorziening/CBS/ROA 
Tabel 2.3

Openstaande vacatures per opleidingssector, Limburg, april 2000

\begin{tabular}{|c|c|c|c|c|c|}
\hline Opleidingssector & aantal & $\begin{array}{c}\text { vacature- } \\
\text { graad } \\
\%\end{array}$ & typering & $\begin{array}{c}\% \text { langdurig } \\
\text { openstaand } \\
\%\end{array}$ & typering \\
\hline Basisonderwijs & - & - & - & - & - \\
\hline $\begin{array}{l}\text { VMBO Theorie } \\
\text { VMBO Landbouw en natuurlijke }\end{array}$ & 600 & 20 & gemiddeld & 21 & laag \\
\hline omgeving & 150 & 60 & hoog & $=$ & - \\
\hline VMBO Techniek & 3.150 & 72 & hoog & 46 & hoog \\
\hline VMBO Economie & 1.225 & 144 & zeer hoog & 34 & gemiddeld \\
\hline VMBO Zorg en welzijn & 1.850 & 123 & hoog & 35 & gemiddeld \\
\hline VMBO Openbare orde en veiligheid & 200 & - & - & 54 & zeer hoog \\
\hline VMBO Totaal & 10.675 & 107 & hoog & 34 & gemiddeld \\
\hline $\begin{array}{l}\text { HAVONWO } \\
\text { MBO Landbouw en natuurlijke }\end{array}$ & 125 & 57 & gemiddeld & 52 & hoog \\
\hline omgeving & 150 & 17 & laag & 26 & laag \\
\hline MBO Techniek & 1.400 & 23 & gemiddeld & 41 & hoog \\
\hline $\begin{array}{l}\text { MBO Dienstverlening en } \\
\text { gezondheidszorg }\end{array}$ & 1.150 & 23 & gemiddeld & 34 & gemiddeld \\
\hline MBO Economie & 1.775 & 30 & gemiddeld & 40 & gemiddeld \\
\hline MBO Openbare orde en velligheid & - & - & - & - & - \\
\hline MBO Totaal & 4.600 & 22 & gemiddeld & 39 & gemiddeld \\
\hline HBO Onderwijs en tolk en vertaler & 375 & 16 & laag & 27 & gemiddeld \\
\hline HBO Landbouw & - & - & - & - & - \\
\hline HBO Techniek & 325 & 20 & gemiddeld & 33 & gemiddeld \\
\hline HBO Paramedisch & 125 & 13 & zeer laag & 55 & zeer hoog \\
\hline HBO Economie & 375 & 23 & gemiddeld & 30 & gemiddeld \\
\hline HBO Sociaal-cultureel & 275 & 28 & gemiddeld & 19 & laag \\
\hline HBO Kunst & - & 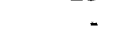 & $=$ & - & - \\
\hline HBO Openbare orde en veiligheid & - & - & - & - & - \\
\hline HBO Totaal & 1.550 & 20 & gemiddeld & 30 & gemiddeld \\
\hline Totaal & 17.100 & 37 & & 36 & \\
\hline
\end{tabular}

Bron: Arbeidsvoorziening/CBS/ROA

N.B. Voor de verschillende opleidingsniveaus is het total niet per definitie gelijk aan de som van de onderliggende opleidingssectoren. Dit verschil komt voort uit het niet opnemen van de categorieeun VMBO Overig. MBO Overig en HBO Overig. 
Elementaire beroepen

11.000

Lagere niet-specialistische beroepen

Lagere docenten sportvakken

Lagere agrarische beroepen

Lagere wiskundige, natuurwet beroepen

Lagere technische beroepen

Lagere transportberoepen

Lagere (para)medische beroepen

Lagere adm., commerciële beroepen e.d.

Lagere beveligingsberoepen

Lagere verzorgende beroepen

Middelbare docenten transport-, sportvakken

Middelbare agrarische beroepen

Middelbare wiskundige, natuurwet beroepen

Middelbare technische beroepen

Middelbare transportberoepen e.d.

Middelbare (para)medische beroepen

Middelbare adm. commerciele beroepen e.d.

Middelbare juridische, bestuurlijke. bev beroepen

Middelbare taallikundige, culturele beroepen

Middelbare beroepen m.b.t. gedrag en maatschappij

Middelbare verzorgende beroepen e.d

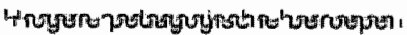

Hogere landbouwkundige beroepen

Hogere wiskundige, natuurwet. beroepen

Hogere technische beroepen

Hogere transportberoepen

Hogere (para)medische beroepen

Hogere adm., commerciele, economische beroepen

Hogere juridische, bestuurlijke. bev beroepen

Hogere taalkundige, culturele beroepen

Hogere beroepen m.b.t.gedpag en maatschappi]

Hogere verzorgende beroepen

Managers (HBO werk - en denkniveau) e.d.

575

-

Wetenschappelijke pedagogische beroepen

Wetenschappelijke landbouwkundige beroepen

Wetenschappelijke wisk., natuurwet beroepen

Wetenschappelijke technische beroepen

Wetenschappelijke (para)medische beroepen e.d. aantal werkloos- typering heid

$\%$ langdurig

zoekend

$\%$ zeer hoog

67

zeer hoog

gemiddeld

60

hoog

6 hoog

10 hoog

-

7 hoog

14

-

zeer hoog

typering

$46 \quad$ laag

52 gemiddeld

55 gemiddeld

58 hoog

56 noog

55

gemiddeld

gemiddeld $\quad 47 \quad$ laag

gemiddeld

gemiddeld

laag

hoog

gemiddeld

46

62

53

gemidideld

zeer hoog

57

hoog

gemiddeld 55 gemiddeld

4 gerniddeld

31

gentitudedib

"noog

$-$

laag

-

zeer laag

laag

laag

laag

zeer hoog

gemiddeld

47

laag

52

gemiddeld gemiddeld

zeer laag

zeer laag 
Tabel 2.4 (vervolg)

Niet-werkende werkzoekenden per beroepssegment, Limburg, april 2000

\begin{tabular}{|c|c|c|c|c|c|}
\hline Beroepssegment & aantal & $\begin{array}{l}\text { werkloos- } \\
\text { heid } \\
\%\end{array}$ & typering & $\begin{array}{l}\text { langdurig } \\
\text { zoekend } \\
\%\end{array}$ & typering \\
\hline $\begin{array}{l}\text { Wetenschappelijke economische, adm. } \\
\text { beroepen e.d. } \\
\text { Wetenschappelijke juridische, bestuurlijke }\end{array}$ & 75 & 2 & laag & 48 & laag \\
\hline $\begin{array}{l}\text { beroepen } \\
\text { Wet. Beroepen m.b.t. gedrag en }\end{array}$ & 75 & - & - & 51 & gemiddeld \\
\hline $\begin{array}{l}\text { maatschappij } \\
\text { Managers (wetenschappelijk werk- en }\end{array}$ & 50 & - & - & 58 & hoog \\
\hline denkniveau) & 125 & 2 & laag & 56 & hoog \\
\hline Totaal & 39.700 & & & 59 & \\
\hline
\end{tabular}

Bron: Arbeidsvoorziening/ROA 
Lagere niet-specialistische beroepen

Lagere docenten sportvakken

Lagere agrarische beroepen

Lagere wiskundige, natuurwetenschappelijke beroepen

Lagere technische beroepen

Lagere transportberoepen

Lagere (para)medische beroepen

Lagere administratieve, commerciele beroepen e.d.

Lagere beveiligingsberoepen

Lagere verzorgende beroepen

Middelbare docenten transport-, sportvakken

Middelbare agrarische beroepen

Middelbare wiskundige, natuunwetenschappelijke beroepen

Middelbare technische beroepen

Middelbare transportberoepen e.d

Middelbare (para)medische beroepen

Middelbare administratıeve, commercièle beroepen e.d

Middelbare juridische, bestuurlijke. beveiligingsberoepen

Middelbare faalkundige, cuiturele beroepen

Middelbare beroepen m.b.t gedrag en maatschappij

Middelbare verzorgende beroepen e.d

Hogere pedagogische beroepen

Hogere landbouwkundige beroepen

Hogere wiskundige, natuurwetenschappelijke beroepen

Hogere technische beroepen

Hogere transportberoepen

Hogere (para)medische beroepen

Hogere adm. commerciele, economische beroepen

Hogere juridische bestuurlijke. beveligingsberoepen

Hogere taalkundige. culturele beroepen

Hogere beroepen m.b.t. gedrag en maatschappi]

Hogere verzorgende beroepen

Managers ( $\mathrm{HBO}$ werk- en denkniveau) e d

Wetenschappelijke pedagogische beroepen

Wetenschappelijke landbouwkundige beroepen

Wetenschappelijke wiskundige, natuunwet. beroepen

Wetenschappelijke lechnische beroepen

Wetenschappelijke (para)medische beroepen e.d.

Wetenschappelijke economische, adm. beroepen e.d.
13

zeer laag

36

21 laag

\section{hoog}

gemiddeld

laag

37

43

47

laag

laag

gemiddeld

42

58

39

gemiddeld

50

gemiddeld

gemiddeld laag

38

35

46

49

gemiddeld

47

gemiddeld

gemiddeld

noog

gemiddeld

45

hoog

zeer hoog 
Tabel 2.5 (vervolg)

Niet-werkende werkzoekenden per beroepssegment en bemiddelingsfase, Limburg, april 2000

Beroepssegment

$\%$ fase 1

typering

$\%$ fase $2+3$

Wetenschappelijke juridische, bestuurlijke beroepen

hoog

Wetenschappelijke beroepen m.b.t. gedrag en maatschappij

Managers (wetenschappelijk werk- en denkniveau)

Totaal

Bron: Arbeidsvoorziening/ROA 
Lagere niet-specialistische beroepen

Lagere docenten sportvakken

Lagere agrarische beroepen

Lagere wiskundige. natuurwetenschappelijke beroepen

Lagere technische beroepen

Lagere transportberoepen

Lagere (para)medische beroepen

Lagere administratıeve. commercièle beroepen e.d.

Lagere beveiligingsberoepen

Lagere verzorgende beroepen

Middelbare docenten transport-, sportvakken

Middelbare agrarische beroepen

Middelbare wiskundige. natuurwetenschappelijke beroepen

Middelbare technische beroepen

Middelbare transportberoepen e d.

Middelbare (para)medische beroepen

Middelbare administratieve. commerciele beroepen e.d.

Middelbare juridische, bestuurlijke, beveiligingsberoepen

Middelbare taalkundige. culturele beroepen

Middetbare beroepen m.b.t. gedrag en maatschappij

Middelbare verzorgende beroepen e.d.

Hogere pedagogische beroepen

Hogere landbouwkundige beroepen

Hogere wiskundige. natuurwetenschappelijke beroepen

Hogere technische beroepen

Hogere transportberoepen

Hogere (para)medische beroepen

Hogere administratieve, commerciéle. economische beroepen

Hogere juridische, bestuurlijke. beveiligingsberoepen

Hogere taalkundige. culturele beroepen

Hogere beroepen m.b t gedrag en maatschappij

Hogere verzorgende beroepen

Managers ( $\mathrm{HBO}$ werk- en denkniveau) e.d

Wetenschappelijke pedagogische beroepen

Wetenschappelijke landbouwkundige beroepen

Wetenschappelijke wiskundige. natuurwetenschappelijke beroepen

Wetenschappelijke technische beroepen

Wetenschappelijke (para)medische beroepen e.d. 
Tabel 2.6 (vervolg)

Kenmerken niet-werkende werkzoekenden per beroepssegment, Limburg, april 2000

Beroepssegment

$\%$ vrouw

$\%$ jongeren

$\%$ ouderen

$(15-29)$

$(50 \cdot 64)$

Wetenschappelijke economische, administratieve beroepen e.d.

Wetenschappelijke juridische, bestuurlijke beroepen

Wetenschappelijke beroepen m.b.t. gedrag en maatschappij

Managers (wetenschappelijk werk-en denkniveau)

Bron: Arbeidsvoorziening/ROA 
Tabel 2.7

Niet-werkende werkzoekenden per opleidingssector, Limburg, april 2000

\begin{tabular}{|c|c|c|c|c|c|}
\hline Opleidingssector & aantal & $\begin{array}{c}\text { werkloos- } \\
\text { held } \\
\%\end{array}$ & typering & $\begin{array}{c}\text { langdurig } \\
\text { zoekend } \\
\%\end{array}$ & typering \\
\hline Basisonderwijs & 7.500 & 16 & hoog & 75 & zeer hoog \\
\hline $\begin{array}{l}\text { VMBO Theorie } \\
\text { VMBO Landbouw en natuurlijke }\end{array}$ & 5.325 & 14 & hoog & 53 & gemiddeld \\
\hline omgeving & 425 & 15 & noog & 50 & gemiddeld \\
\hline VMBO Techniek & 4.900 & 10 & hoog & 56 & gemiddeld \\
\hline VMBO Economie & 3.325 & 28 & zeer hoog & 57 & hoog \\
\hline VMBO Zorg en welzjin & 4.975 & 25 & zeer hoog & 68 & hoog \\
\hline VMBO Openbare orde en veiligheid & 150 & - & - & 34 & zeer laag \\
\hline VMBO Totaal & 20.959 & 17 & noog & 57 & hoog \\
\hline $\begin{array}{l}\text { HAVO NWO } \\
\text { MBO Landbouw en natuurlijke }\end{array}$ & 1.850 & 8 & gemiddeld & 51 & gemiddeld \\
\hline omgeving & 125 & 1 & zeer laag & 41 & laag \\
\hline $\begin{array}{l}\text { MBO Techniek } \\
\text { MBO Dienstverlening en }\end{array}$ & 2750 & 4 & gemiddeld & 45 & laag \\
\hline gezondheidszorg & 1775 & 3 & gemiddeld & 54 & gemiddeld \\
\hline MBO Economie & 2400 & 4 & gemiddeld & 45 & laag \\
\hline MBO Openbare orde en veiligheid & 75 & 2 & laag & 55 & gemiddeld \\
\hline MBO Totaal & 9082 & 4 & gemiddeld & 48 & gemiddeld \\
\hline HBO Onderwis en tolk en vertaler & 325 & 1 & zeer laag & 59 & hoog \\
\hline HBO Landbouw & - & - & - & $=$ & \\
\hline HBO Techniek & 150 & 1 & zeer laag & 57 & hoog \\
\hline HBO Paramedisch & 50 & 4 & zeer laag & - & - \\
\hline HBO Economie & 100 & 1 & zeer laag & 48 & gemiddeld \\
\hline HBO Sociaal-culturee & 150 & 1 & zeer laag & 46 & gemiddeld \\
\hline HBO Kunst & 150 & 5 & gemiddeld & 71 & zeer hoog \\
\hline HBO Openbare orde en veiligheid & - & - & - & - & \\
\hline HBO Totaal & 961 & 1 & zeer laag & 57 & hoog \\
\hline WO Totaal & 595 & 3 & gemiddeld & 55 & gemiddeld \\
\hline Totaal & 39700 & & & 59 & \\
\hline
\end{tabular}

Bron Arbeidsvoorziening/ROA

NB Voot de verschillende opleidingsniveaus is hel totaal niel per definitie gelijk aan de som van de ondertiggende opleidingssectoren. Dit verschil komt voort uit het niet opnemen van de categorieen $\checkmark M B O$ Overig. MBO Overig en HBO Overig 
Tabel 2.8

Niet-werkende werkzoekenden per opleudingssector en bemiddelingsfase. Limburg. april 2000

\begin{tabular}{|c|c|c|c|}
\hline Opleidingssector & $\%$ fase 1 & typering & $\%$ fase $2+3$ \\
\hline Basisonderwijs & 6 & zeer laag & 32 \\
\hline VMBO Theorie & 22 & gemiddeld & 40 \\
\hline VMBO Landbouw en natuurlijke omgeving & 21 & gemiddeld & 39 \\
\hline VMBO Techniek & 21 & gemiddeld & 38 \\
\hline VMBO Economie & 20 & gemiddeld & 48 \\
\hline VMBO Zorg en Welzijn & 12 & laag & 36 \\
\hline VMBO Openbare orde en velligheid & 38 & zeer hoog & 41 \\
\hline VMBO Totaal & 19 & laag & 41 \\
\hline HAVOMWO & 31 & hoog & 40 \\
\hline MBO Landbouw en natuurlijke omgeving & 41 & zeer hoog & 35 \\
\hline MBO Techniek & 28 & gemiddeld & 42 \\
\hline MBO Dienstverlening en gezondheidszorg & 21 & gemiddeld & 42 \\
\hline MBO Economie & 26 & gemiddeld & 43 \\
\hline MBO Openbare orde en velligheld & - & - & 61 \\
\hline MBO Totaal & 27 & gemiddeld & 42 \\
\hline HBO Onderwijs en tolk en vertaler & 26 & gemiddeld & 37 \\
\hline HBO Landbouw & - & - & - \\
\hline HBO Techniek & 23 & gemiddeld & 37 \\
\hline HBO Paramedisch & - & - & - \\
\hline HBO Economie & 31 & hoog & 42 \\
\hline HBO Sociaal-cultureel & 33 & hoog & 36 \\
\hline HBO Kunst & 17 & laag & 54 \\
\hline HBO Openbare orde en veiligheid & - & - & - \\
\hline HBO Totaal & 25 & gemiddeld & 41 \\
\hline WO Totaal & 22 & gemiddeld & 51 \\
\hline Totaal & 19 & - & 39 \\
\hline
\end{tabular}

Bron: Arbeidsvoorziening/ROA 
Tabel 2.9

Kenmerken niet-werkende werkzoekenden per opleidingssector, Limburg, april 2000

Opleidingssector

$\%$ vrouw

$\%$ jongeren

$(15-29)$

$\%$ ouderen

$(50-64)$

Basisonderwijs

46

12

37

VMBO Theorie

56

37

29

24

VMBO Landbouw en natuurlijke omgeving

\section{5}

20

VMBO Techniek

VMBO Economie

66

23

16

$98 \quad 13$

VMBO Zorg en welzijn

VMBO Openbare orde en veiligheid

VMBO Totaal

HAVONWO

$49 \quad 27$

27

MBO Techniek

MBO Dienstverlening en gezondheidszorg

MBO Openbare orde en veiligheid

MBO Totaal

HBO Onderwijs en tolk en vertaler

HBO Landbouw

HBO Techniek

HBO Paramedisch

HBO Economie

HBO Sociaal-cultureel

HBO Kunst

HBO Openbare orde en veiligheid

WO Totaal 
Tabel 2.10

Discrepanties per bedrijfssector, Limburg, april 2000

Bedrijfssector

arbeidsmarktkrapte

typering

Landbouw en visserij $\quad 0,48$

Voeding $\quad 1,32$

Chemie $\quad 1,39$

Metaal en elektrotechniek $\quad 1,77$

Overige industrie $\quad 1,22$

Energie $\quad 2,15$

Bouw en onroerend goed $\quad 2,53$

Handel en reparatie $\quad 3,07$

Transport en communicatie $\quad 1,93$

Bank- en verzekeringswezen $\quad 3,37$

Horeca en zakelijke dienstveriening $\quad 2,70$

$\begin{array}{ll}\text { Kwartaire diensten } & 2,82\end{array}$

Overheid en onderwijs $\quad 2,25$

zeer laag

hoog

hoog

hoog

hoog

zeer hoog

zeer hoog

zeer hoog

hoog

zeer hoog

zeer hoog

zeer hoog

Totaal

2,33

Bron: Arbeidsvoorziening/CBS/ROA 
Elementaire beroepen

Lagere niet-specialistische beroepen

Lagere docenten sportvakken

Lagere agrarische beroepen

Lagere wiskundige. natuurwet beroepen

Lagere technische beroepen

Lagere transportberoepen

Lagere (para)medische beroepen

Lagere adm., commerciele beroepen e.d.

Lagere beveiligingsberoepen

Lagere verzorgende beroepen

Middelbare docenten transport-, sportvakken

Middelbare agrarische beroepen

Middelbare wiskundige, natuurwet beroepen

Middebare technische beroepen

Middelbare transportberoepen e.d

Middelbare (para)medische beroepen

Middelbare adm., commerciele beroepen e $\mathrm{d}$.

Middelbare juridische, bestuurlijke, bev. beroepen

Middelbare taakkundige, culturele beroepen

Middelbare beroepen $m . b \mathrm{t}$ gedrag en maatschappij

Middelbare verzorgende beroepen e.d

Hogere pedagogische beroepen

Hogere landbouwkundige beroepen

Hogere wiskundige, nat. beroepen

Hogere technische beroepen

Hogere transportberoepen

Hogere (para)medische beroepen

Hogere adm, commerciële, economische beroepen

Hogere juridische, bestuurlijke, bev beroepen

Hogere taalkundige, culturele beroepen

Hogere beroepen m.b.t. gedrag en maatschappij

Hogere verzorgende beroepen

Managers (HBO werk - en denkniveau) e d

Totaal
2.54 zeer noog

0.53

hoog

zeer hoog

hoog

hoog

zeer hoog

zeer hoog

zeer hoog

1.28

0.02

0.35

1.33

1.43

1.77

hoog

0.18

zeer hoog

$-$

1,01

0.41

$\begin{array}{ll}\text { zeer hoog } & 0.92 \\ \text { hoog } & 0.17\end{array}$

$\begin{array}{ll}\text { zeer hoog } & 0,92 \\ \text { hoog } & 0.17\end{array}$

zeer laag

hoog

0,16

zeernoog $\quad 0,93$

zeer hoog

1,81

zeer hoog

1,61

zeer hoog

2,48

zeer hoog

1,15

laag

zeer hoog

1.97

zeer hoog

0,89

0.63

Bron: Arbeidsvoorziening/CBS/ROA 
Tabel 2.12

Discrepanties per opleidingssector, Limburg, april 2000

\begin{tabular}{|c|c|c|c|}
\hline Opleidingstype & rbeidsmarktkrapte & typering & knelpuntsindicator \\
\hline Basisonderwijs & - & - & - \\
\hline VMBO Theorie & 0,52 & laag & . \\
\hline VMBO Landbouw en natuurlijke omgeving & 1,58 & hoog & 0,31 \\
\hline VMBO Techniek & 3,08 & zeer hoog & 1,14 \\
\hline VMBO Economie & 1,84 & hoog & 0,35 \\
\hline VMBO Zorg en welzijn & 3,13 & zeer hoog & 0,70 \\
\hline VMBO Openbare orde en veiligheid & 3,39 & zeer hoog & 2,20 \\
\hline VMBO Totaal & 2,38 & zeer hoog & 0,69 \\
\hline HAVONWO & 0,23 & zeer laag & " \\
\hline MBO Landbouw en natuurlijke omgeving & 3,29 & zeer hoog & 2,67 \\
\hline MBO Techniek & 1,81 & hoog & 0,54 \\
\hline MBO Dienstverlening en gezondheidszorg & 3,11 & zeer hoog & 1,04 \\
\hline MBO Economie & 2,81 & zeer hoog & 1,12 \\
\hline MBO Openbare orde en veiligheid & 0,13 & zeer laag & $\therefore$ \\
\hline MBO Totaal & 1,89 & hoog & 0,57 \\
\hline HBO Onderwijs en tolk en vertaler & 4,53 & zeer hoog & 2,44 \\
\hline HBO Landbouw & . & - & 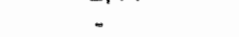 \\
\hline HBO Techniek & 8,54 & zeer hoog & 4,65 \\
\hline HBO Paramedisch & 10,15 & zeer hoog & 6,61 \\
\hline HBO Economie & 12,53 & zeer hoog & 8,24 \\
\hline HBO Sociaal-cultureel & 5,70 & zeer hoog & 4,33 \\
\hline HBO Kunst & 0,46 & zeerlaag & . \\
\hline HBO Openbare orde en veiligheid & - & - & - \\
\hline HBO Totaal & 6,43 & zeer hoog & 3,39 \\
\hline Totaal & 2,33 & & 0,63 \\
\hline
\end{tabular}

Bron: Arbeidsvoorziening/CBS/ROA 
Tabol 213

Werkloosheid (in procenten) onder MBO-schoolverlaters per opleidingssector. Limburg en Nederland. 1999

Limburg typering Nederland typening

MBO Landbouw en natuurlijke omgeving

MBO Techmek

MBO Dienstverlening en gezondheidszorg

MBO Economie

MBO Totaal

$\begin{array}{lll}\text { gemiddeld } & 1 & \text { laag } \\ \text { laag } & 1 & \text { laag } \\ \text { laag } & 2 & \text { gemiddeld } \\ & 2 & \text { gemiddeld } \\ & 2 & \end{array}$

Bron ROA 
Tabel 2.14

Intredewerkloosheid (langer dan 4 maanden, in procenten) onder MBO-schoolverlaters per opleidingssector. Limburg en Nederland, 1999

\begin{tabular}{lcccc}
\hline & Limburg & typering & Nederland typering \\
\hline MBO Landbouw en natuurlijke omgeving & & & & \\
MBO Techniek & - & - & 6 & gemiddeld \\
MBO Dienstverlening en gezondheidszorg & 6 & gemiddeld & 3 & laag \\
MBO Economie & 5 & laag & 3 & laag \\
MBO Totaal & 4 & & 4 & 4 \\
\hline
\end{tabular}

Bron: ROA 
Tabel 215

Gemiddeld bruto maandloon (In guldens) van MBO-schoolverlaters per opleidingssector. Limburg en Nederland, 1999

Limburg typering Nederiand typering

$\begin{array}{lllll}\text { MBO Landbouw en natuurlijke omgeving } & - & - & 2.550 & \text { gemiddeld } \\ \text { MBO Techniek } & 3.500 & \text { gemiddeld } & 3.300 & \text { gemiddeld } \\ \text { MBO Dienstverlening en gezondheidszorg } & 3.250 & \text { gemiddeld } & 2.950 & \text { gemiddeld } \\ \text { MBO Economie } & 2.800 & \text { gemiddeld } & 2.600 & \text { gemiddeld } \\ \text { MBO Totaal } & 3.150 & & 3.000\end{array}$

Bron. ROA 
Tabel 2.16

Percentage MBO-schoolverlaters met een flexibele aanstelling per opleidingsseckor, Limburg en Nederland. 1999

Limburg typering Nedertand typering

MBO Landbouw en natuurijike omgeving MBO Techniek

MBO Dienstverlening en gezondheidszorg

MBO Economie

$\begin{array}{llll}20 & \text { laag } & 31 & \text { gemiddeld } \\ 25 & \text { laag } & 18 & \text { zeer laag } \\ 36 & \text { gemiddeld } & 29 & \text { gemiddeld } \\ 27 & & 33 & \text { gemiddeld } \\ & & 26 & \end{array}$

MBO Totaal

Bron: ROA

Van flexibel werk is sprake bij uitzendkrachten, oproepkrachten, invalkrachten, contracten zonder een vast aantal arbeidsuren en indien geen vast dienstverband is overeengekomen. 
Tabel 2.17

Percentage MBO-schoolverlaters dat in deeltjj (12 tot 32 uur) werkt per opleidingssector, Limburg en Nederland, 1999

\section{Limburg typering Nederiand typering}

$\begin{array}{lcccc}\text { MBO Landbouw en natuurlike omgeving } & - & - & 24 & \text { gemiddeld } \\ \text { MBO Techniek } & 7 & \text { laag } & 5 & \text { laag } \\ \text { MBO Dienstwerlening en gezondheidszorg } & 43 & \text { gemiddeld } & 53 & \text { hoog } \\ \text { MBO Economie } & 16 & \text { laag } & 20 & \text { gemiddeld } \\ \text { MBO Totaal } & 24 & & 27\end{array}$

Bron ROA 
Tabel 2.18

Onderbenutting van MBO-schoolverlaters per opleidingssector. Limburg en Nederland, 1999

\begin{tabular}{lcccc}
\hline & Limburg & typering & Nederland typering \\
\hline MBO Landbouw en natuurlijke omgeving & - & - & 44 & hoog \\
MBO Techniek & 36 & gemiddeld & 38 & 9 gemiddeld \\
MBO Dienstverlening en gezondheidszorg & 27 & gemiddeld & 36 & gemiddeld \\
MBO Economie & 23 & gemiddeld & 40 & gemiddeld \\
MBO Totaal & 28 & & 38 &
\end{tabular}

\section{Bron: ROA}

Onderbenutting betreft de mate waarin arbeidskrachten werkzaam zijn op een functieniveau dat lager is dan hun oplerdingsniveau 
Tabel 2.19

Percentage MBO-schoolverlaters dat buiten de eigen vakrichting werkzaam is per opleidingssector. Limburg en Nederland, 1999

\begin{tabular}{lclcl} 
Limburg & Limburg & typering & Nederland typering \\
\hline MBO Landbouw en natuurlijke omgeving & & & & \\
MBO Techniek & 33 & gemiddeld & 22 & gemiddeld \\
MBO Dienstverlening en gezondheidszorg & 18 & laag & 26 & gemiddeld \\
MBO Economie & 38 & gemiddeld & 46 & hoog \\
MBO Totaal & 29 & & 31 &
\end{tabular}

Bron ROA 
(1)

The

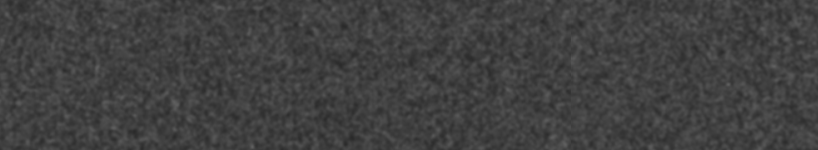

7.

$\log _{20}$

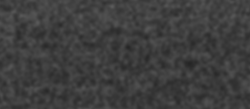

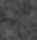

(5)

of

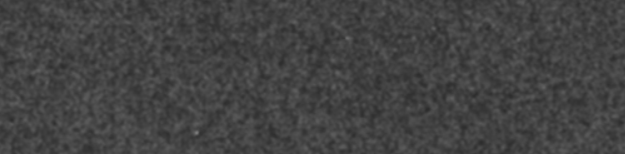

3.7.

(1)

Whans

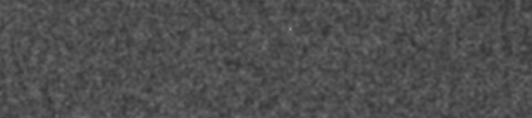

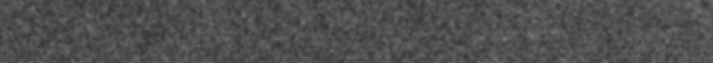

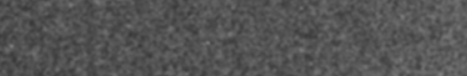

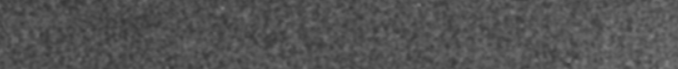
20.7.

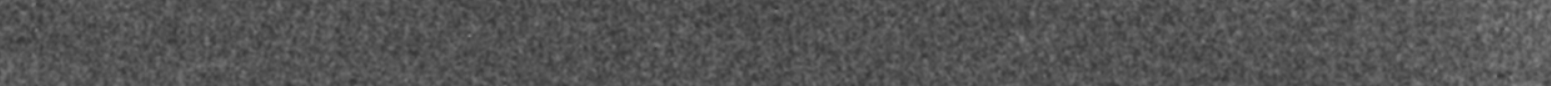

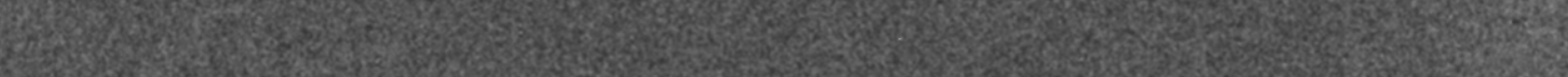

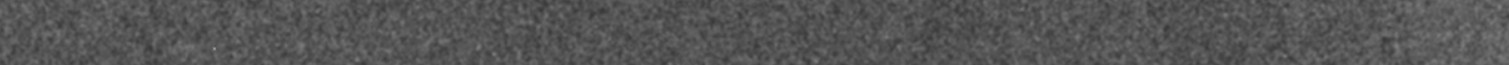

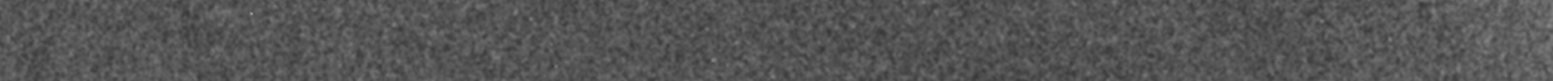

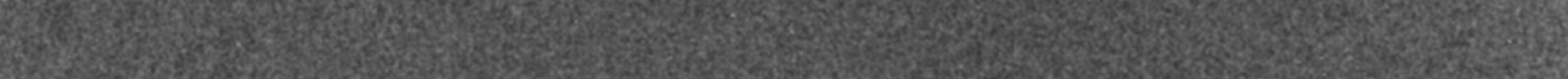

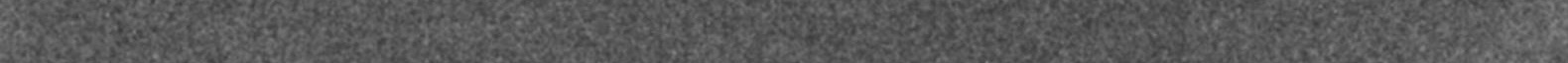

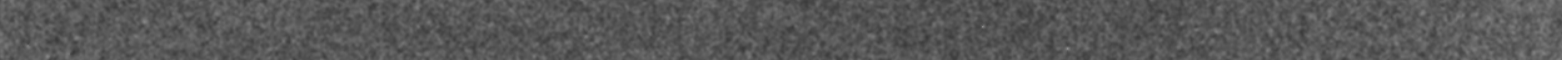
7.7. W 3.

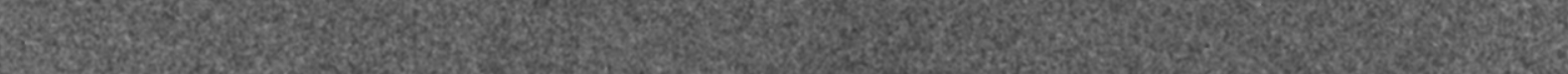


Tabel 3.1

Verwachte uitbreidingsvraag per bedrijfssector (in percentage van de werkgelegenheid), Limburg, 2001

$\begin{array}{lll}\text { Bedriffssector } & \% & \text { typering }\end{array}$

Landbouw en visserij

Voeding

Chemie

Metaal en elektrotechniek

Overige industrie

Energie

Bouw en onroerend goed

Handel en reparatie

Transport en communicatie

Bank-en verzekeringswezen

$-1,1$

1,0

1,0

1,6

1,5

0,3

4,1

3,2

2,9

4,3

Horeca en zakelijke dienstverlening

2,1

Kwartaire diensten

3,3

Overheid en onderwijs

0,8

zeer laag

laag

laag

gemiddeld

gemiddeld

laag

gemiddeld

hoog

gemiddeld

zeer hoog

gemiddeld

hoog

Totaal

2,0

laag

Bron: Arbeidsvoorziening/CPB/ROA 
Leraar basisonderwijs

Docenten exacte, medische en verzorgende vakken (2e graads)

Docenten exacte, medische en verzorgende vakken (1e graads)

Docenten landbouw en techniek (2e graads)

Docenten landbouw en technek (1e graads)

Docenten economisch-administratieve vakken (2e graads)

Docenten economisch-administratieve vakken (1e graads)

Docenten talen en expressie

Docenten letteren (1e graads)

Docenten sociale vakken (2e graads)

Docenten sociale vakken (1e graads)

Docenten 2e graads zonder specialisatie

Docentien 1 graads zonder specialisatie

Onderwjskundig medewerkers

Onderwijskundigen en pedagogen

Rij-instructeurs

Zweminstructeurs

Sportinstructeurs

Tolken, vertalers en schrijvers

Bibliotheekassistenten

Bibluothecarissen

Grafisch ontwerpers

Kunstenaars

Geestelijk verzorgers

Geestelijken

Journalisten

Taakundigen

Agrarische hulparbeiders

Agrarische arbeiders

Agrarische vakkrachten

Milieuhygienisten en agrarisch vertegenwoordigers

Landbouwkundigen

Landbouwmachinebestuurders en vissers

Agrarische bedrijfshoofden

Productiemedewerkers

Laboratorium-assistenten

Laboranten

Technisch analusten

Natuurwetenschappers

Concierges

Hoofden technische dienst

Werktuigbouwkundigen

Bouwwakkers

Aannemers en installateurs

Architecten on bouwkundig projectleiders

Weg* en waterbouwkundigen

Weg- en waterbouwkundige arbeiders

Weg en waterbouwkundige vakkrachten

Weg- on waterbouwkundig ontwerpers en projectleiders

Metaalarbeiders

Bankwerkers en lassers

Bedrijtshoofden metaalbewerking

Assembleurs

Monteurs

Werktuigbouwkundig ontwerpers en hoofden technische dienst

Elektronicamonteurs

Monteurs en controleurs elektrotechnische producten

Elektromonteurs

Elektrotechnisch ontwerpers en bedrijfshoofden

Elektrotechnici

Grafisch productiepersoneel
0.9

- gemiddeto

- gemiddeld

- gemiddeld

- gemiddeld

- gemiddeld

- gemiddeld

- gemidideld

- gemiddeld

- gemidideld

- gemiddeld

- gemiddeld

- gemiddeld

- gemiddelo

- $\quad$ gemiddeld

- gemiddeld

- gemiddeld

- gemiddeld

- gemiddeld

- gerniddeld

- gemiddeld

- gemiddeld

- hoog

- gemiddeld

- zeer hoog

- zeer noog

- hoog

- zeer laag

$-0.5 \quad z e e r$ laag

- zeer laag

- zeer laag

- zeer laag

- zeer laag

$-0,5 \quad$ zeer laag

0,3 laag

- zeer laag

- laag

- laag

gemiddeld

laag

laag

zeer laag

laag

$0.4 \quad$ laag

- gemiddeld gemiddeld

laag

0.5 gemidideld

- laag

0,3 laag

$0,3 \quad$ laag

- laag

0,2 zeer laag

0.4 laag

- laag

- laag

- laag

$0,4 \quad$ laag

- zeer laag

- zeer laag

- laag 
Tabel 3.2 (vervolg)

Verwachte uitbre $d i n g s v r a a g$ per beroepsgroep (in peroentage van de werkgelegenherd). Limburg, 2001

Beroepsgroep

$\% \quad$ typering

Grafische vakkrachten

Mechanisch operators

Procesoperators

Procestechnologen

Materiaalkundigen

Confectie-arbeiders

Schoen-en kleermakers

Laders en lossers

Chauffeurs

Schippers en conducteurs

Vliegers, scheepskapiteins en leidinggevenden transport

Stewards

Verplegenden en doktersassistenten

Therapeuten en verpleegkundigen

Artsen

Apothekersassistenten en medisch laboranten

Medisch analisten

Apothekers

Afdelıngshoofden zorginstelling

Kantoorhulpen, inpakkers en colporteurs

Ondersteunende administratieve hulpkrachten

Bedrijfshoofden

Economen

Productieplanners

Organisatie-adviseurs

Organisatiedeskundigen

Receptionisten en administratıeve employees

Boekhouders en secretaresses

Assistent accountants

Accountants

Verzekeringsagenten

Commercieel employees

Commercieel medewerkers

Technisch-commercieel employees

Technisch-bedrıfskundig medewerkers

Jundisch en fiscaal medewerkers

Juridisch, bestuurlijk medewerkers

Junsten

Administratieve transportemployees

Leidinggevenden

Managers

Medisch secretaresses

Programmeurs

Systeemanalisten

informatici

Technisch systeemanalisten

Activiteitenbegeleiders en medewerkers arbeidsbemiddeling

Medewerkers sociaal-cultureel werk en personeel en arbeid

Hoofden sociaal-cultureel werk en personeel en arbeid

Sociaal-wetenschappelijk medewerkers

Sociaal-wetenschappelijk onderzoekers

Vakkenvullers.

Interieurverzorgers

Verkopers

Winkeliers

Hulpkrachten horeca en verzorging

Ziekenverzorgenden

Verzorgend personeel

Café- en snackbarhouders

Bedrijfshoofden horeca

Bakkers en slagers

- gemiddeld

0,4 laag

0,3 laag

- laag

- laag

0.3 laag

- laag

2.4 gemiddelo

2.4 gemiddeld

- zeer hoog

- gemiddeld

- zeer hoog

2,0 gemiddeld

2.1 gemiddeld

2.4 gemiddeld

1.8 gemiddeld

- gemiddeld

- gemiddeld

- hoog

2.8 gemiddeld

- zeer hoog

- hoog

- hoog

3.2 hoog

- hoog

- zeer hoog

hoog

3.3 hoog

3.7 hoog

- hoog

- hoog

3.5 hoog

3.4 noog

- noog

- gemiddelo

3.0 hoog

- hoog

4.5 zeer hoog

- hoog

34 hoog

$3.1 \operatorname{hoog}$

- hoog

5.3 zeer hoog

5.4 zeer hoog

- zeer hoog

- hoog

4.3 noog

43 noog

- zeer hoog

- hoog

- zeer hoog

- gemiddeld

2,4 gemiddeld

2,3 gemiddeld

2,6 gemiddeld

2,5 gemiddeld

2,5 gemiddeld

2,4 gemiddeld

- gemiddeld

2,4 gemiddeld

- gemiddeld 
Tabel 3.2 (vervolg)

Verwachte uitbreidingsvraag per beroepsgroep (in percentage van de werkgelegenheid). Limburg, 2001

Beroepsgroep $\quad \% \quad$ typenng

Asp. politieagenten, soldaten en beveiligingshuipkrachten

Politieagenten, onderofficieren en beveiligingsemployees

Politie-inspecteurs en officieren

Brandweerlieden

gemiddeld

1,0 gemiddeld

- gemiddeld

- gemiddeld

Totaal

2,0

Bron ROA 
Tabel 3.3

Verwachte netto vervangingsvraag per beroepsgroep (in percentage van de werkgelegenneid). Limburg. 2001

Leraar basisonderwijs

Docenten exacte, medische en verzorgende vakken ( $2 \mathrm{e}$ graads)

Docenten exacte. medische en verzorgende vakken (1e graads)

Docenten landbouw en techniek ( 2 e graads)

Docenten landbouw en techmek (le graads)

Docenten economisch-administratieve vakken (2e graads)

Docenten economisch-admunistratieve vakken (le graads)

Docenten talen en expressie

Docenten letteren (1e graads)

Docenten sociale vakken (2e graads)

Docenten socuale vakken (1e graads)

Docenten 2e graads zonder specialisatie

Docenten 1 e graads zonder specialisatie

Onderwijskundig medewerkers

Onderwijskundigen en pedagogen

Rij-instructeurs

Zweminstructeurs

Sportınstructeurs

Tolken. vertalers en schrijwers

Bibliotheekassistenten

Bibliothecanssen

Grafisch ontwerpers

Kunstenaars

Geestelijk verzorgers

Geesteliiken

Journalisten

Taalkundigen

Agrarısche hulparbeiders

Agrarische arbeiders

Agrarısche vakkrachten

Milıeuhygıenisten en agrarısch vertegenwoordigers

Landbouwkundigen

Landbouwmachinebestuurders en vissers

Agrarische bedrijfshoofden

Productiemedewerkers

Laboratorium-assistenten

Laboranten

Technisch analisten

Natuurwetenschappers

Concièrges

Hoofden technische dienst

Werkturgbouwkundigen

Bouwvakkers

Aannemers en installateurs

Architecten en bouwkundig projectleiders

Weg- en waterbouwkundigen

Weg-en waterbouwkundige arbeiders

Weg- en waterbouwkundige vakkrachten

Weg-en waterbouwkundig ontwerpers en projectleiders

Metaalarbeiders

Bankwerkers en lassers

Bedrijfshoofden metaalbewerking

Assembleurs

Monteurs

Werktuigbouwkundig ontwerpers en hoofden technische dienst

Elektronicamonteurs

Monteurs en controleurs elektrotechnische producten

Elektromonteurs

Elektrotechnisch ontwerpers en bedrijfshoofden

Elektrotechnici
3,3 gemiddeld

laag

gemiddeld

gemiddelo

laag

gemiddeld

gemiddeld

gemuddeld

hoog

zeer hoog

gemiddeld

gemiddeld

hoog

laag

laag

zeer laag

zeer laag

zeer laag

laag

zeer laag

zeer laag

zeer laag

zeer laag

laag

zeer hoog

zeer laag

laag

laag

6.5 zeer hoog

gemicceld

laag

zeer laag

zeer hoog

noog

gemiddeld

gemiddeld

gemiddeld

gemiddeld

laag

zeer hoog

gemiddeld

lavg

4.7 gemidaeld

5.6 hoog

hoog

laag

gemiddeld

5,9 hoog

zeer hoog

4,6 gemiddeld

4,1 gemiddeld

- gemiddeld

$2,7 \quad$ laag

5,0 hoog

- gemiddeld

gemiddeld

- gemiddeld

$4,9 \quad$ hoog

laag

laag 
Tabel 3.3 (vervolg)

Verwachte netto vervangingswraag per beroepsgroep (in percentage van de werkgelegenheid). Lumburg. 2001

Grafisch productiepersoneel

Grafische vakkrachten

Mechanisch operators

Procesoperators

Procestechnologen

Materiaakundigen

Confectie-arbeiders

Schoen-en kleermakers

Laders en lossers

Chauffeurs

Schippers en conducteurs

Vliegers, scheepskapiteins en leidinggevenden transport

Stewards

Verplegenden en doktersassistenten

Therapeuten en verpleegkundigen

Artsen

Apothekersassistenten en medisch laboranten

Medisch analisten

Apothekers

Afdelingshoofden zorginstelling

Kantoorhulpen, inpakkers en colporteurs

Ondersteunende admınistratieve hulpkrachten

Bedrifshoofden

Economen

Productieplanners

Organisatie-adviseurs

Organisatiedeskundigen

Receptionisten en administratieve employees

Boekhouders en secretaresses

Assistent accountants

Accountants

Verzekeringsagenten

Commercieel employees

Commercieel medewerkers

Technisch-commercieel employees

Technisch-bedrifskundig medewerkers

Juridisch en fiscaal medewerkers

Juridisch, bestuurlijk medewerkers

Juristen

Admunistratieve transportemployees

Leidinggevenden

Managers

Medisch secretaresses

Programmeurs

Systeemanalisten

Infomatici

Technisch systeemanalisten

Activiteitenbegeleiders en medewerkers arbeidsbemiddeling

Medewerkers sociaal-cultureel werk en personeel en arbeid

Hoofden sociaal-cultureel werk en personeel en arbeid

Sociaal-wetenschappelijk medewerkers

Sociaal-wetenschappelijk onderzoekers

Vakkenvullers

Interieurverzorgers

Verkopers

Winkeliers

Hulpkpachten horeca en verzorging

Ziekenverzorgenden

Verzorgend personeel

Cafe-en snackbarhouders

\section{hoog}

- hoog

5.0 hoog

3,7 gemiddeld

- laag

- gemiddelo

4.1 gemiddeld

- zeer hoog

5.3 hoog

6.0 hoog

- zeer hoog

- zeer hoog

- zeer hoog

1,2 laag

1.4 laag

1.3 laag

0,4 zeer laag

- laag

* zeer laag

- laag

0.2 zeer laag

- zeer hoog

- hoog

- gemiddeld

4. 1 gemiddeld

- gemiddeld

- gemiddela

4.1 gemiddeld

4.8 gemiddeld

4,4 gemiddeld

- gemididela

- gemiddeld

4.7 gemidideld

4.4 gemiddeld

- hoog

- gemiddeld

4.3 gemiddeld

- hoog

4,3 gemiddeld

- hoog

4.9 hoog

4.3 gemiddela

- gemiddeld

3.1 gemiddeld

1.6 laag

- gemiddeld

laag

$2,6 \quad$ laag

4,3 gemiddeld

- laag

- hoog

- laag

- zeer hoog

4,4 gemiddeld

6,2 hoog

6,3 hoog

6,3 hoog

5,4 hoog

5,9 hoog

- gemiddeld 
Tabel 3.3 (vervolg)

Verwachte netto vervangingsvraag per beroepsgroep (in percentage van de werkgelegenheid). Limburg, 2001

Bedrijfshoofden horeca

Bakkers en slagers

Asp. politieagenten, soldaten en beveiligingshulpkrachten

Politieagenten, onderofficieren en beveiligingsemployees

Politie-inspecteurs en officieren

Brandweerlieden

Totaal

Bron: ROA

\section{$4,9 \quad h o o g$}

- gemiddeld

- zeer hoog

4,5 gemiddeld

- zeer hoog

- gemiddela

4,4 
Leraar basisonderwijs

Dacenten exacte. medische en verzorgende vakken (2e graads)

Docenten exacte. medische en verzorgende vakken (1e graads)

Docenten landbouw en techniek (2e graads)

Docenten landbouw en techniek (1e graads)

Docenten economisch-administratieve vakken (2e graads)

Docenten economisch-administratieve vakken (1e graads)

Docenten talen en expressie

Docenten letteren (1e graads)

Docenten sociale vakken ( 2 e graads)

Docenten sociale vakken (1e graads)

Docenten $2 e$ graads zonder specialisatie

Docenten 1e graads zonder specialisatue

Onderwijskundig medewerkers

Onderwijskundigen en pedagogen

Rijwinstructeurs

Zweminstructeurs

Sportinstructeurs

Tolken. vertalers en schrijvers

Bibliotheekassistenten

Bibliothecarissen

Grafisch ontwerpers

Kunstenaars

Geestelifk verzorgers

Geesteliken

Journalisten

Taalkundigen

Agrarische hulparbeiders

Agrarische arbeiders

Agrarische vakkrachten

Milieuhygiènisten en agrarisch vertegenwoordigers

Landbouwkundigen

Landbouwmachinebestuurders en vissers

Agrarische bedrijfshoofden

Productiemedewerkers

Laboratorium-assistenten

Laboranten

Technisch analisten

Natuuwetenschappers

Concitirges

Hoofden technische dienst

Werktuigbouwkundigen

Bouwvakkers

Aannemers on instaliateurs

Architecten en bowwkundig projectleiders

Weg- en waterbouwkundigen

Weg. en waterbouwkundige arbeiders

Weg- en waterbouwkundige vakkrachten

Weg- en waterbouwkundig ontwerpers en projectleiders

Metaalarbeiders

Bankwerkers en lassers

Bedrijfshoofden metaalbewerking

Assembleurs

Monteurs

Werktuigbouwkundig ontwerpers en hoofden technische dienst

Elektronicamonteurs

Monteurs en controleurs elektrotechnische producten

Elektromonteurs

Elektrotechnisch ontwerpers en bedrijfshoofden

Elektrotechnici

Grafisch productiepersoneel
4.2

- laag

- gemiddeld

- gemiddeld

- laag

- gemiddela

- laag

- gemiddeld

- gemiddeld

- hoog

- gemiddeld

- gemiddeld

- gemiddeld

- laag

- laag

- zeer laag

- zeer laag

- zeer laag

- laag

- zeer laag

- laag

- zeer laag

- laag

- laag

- zeer hoog

- gerniddeld

- gemiddeld

- zeer laag

6.5 gemiddeld

- gemiddeld

- zeer laag

- zeer laag

- zeer hoog

6,4 gemiddeld

4,5 gemiddeld

- gemiddeld

- laag

- laag

- laag

- hoog

- gemiddeld

- zeer laag

5.1 gemiddeld

6.0 gemiddeld

- gemiddeld

- laag

- gemiddeld

6.4 gemiddeld

- gemiddeld

4,9 gemiddeld

4,4 gemidideld

- gemiddeld

2,9 laag

5,4 gemiddeld

- gemiddeld

- gemiddeld

- laag

5.3 gemiddeld

- laag

- zeer laag

- gemiddeld 
Chauffeurs

Schippers en conducteurs

Vliegers, scheepskapiteins en leidinggevenden transport

Stewards

Verplegenden en doktersassistenten

Therapeuten en verpleegkundigen

Artsen

Apothekersassistenten en medisch laboranten

Medisch analisten

Apothekers

Afdelingshoofden zorginstelling

Kantoorhulpen, inpakkers en colporteurs

Ondersteunende admınistratieve hulpkrachten

Bedrifshoofden

Economen

Productieplanners

Organisatie-adviseurs

Organisatiedeskundigen

Receptionisten en administratieve employees

Boekhouders en secretaresses

Assistent accountants

Accountants

Verzekeringsagenten

Commercieel employees

Commercieel medewerkers

Technisch-commercieel employees

Technisch-bedrijfskundig medewerkers

Juridisch en fiscaal medewerkers

Juridisch, bestuurlijk medewerkers

Juristen

Administratieve transportemployees

Leidinggevenden

Managers

Medisch secretaresses

Programmeurs

Systeemanalisten

Informatici

Technisch systeemanalisten

Activiteitenbegeleiders en medewerkers arbeidsbemiddeling

Medewerkers sociaal-cultureel werk en personeel en arbeid

Hoofden sociaal-cultureel werk en personeel en arbeid

Sociaal-wetenschappelijk medewerkers

Sociaal-wetenschappelijk onderzoekers

Vakkenvullers

Interieurverzorgers

Verkopers

Winkeliers

Hulpkrachten horeca en verzorging

Ziekenverzorgenden

Verzorgend personeel

Café-en snackbarhouders

Bedrijfshoofden horeca

Bakkers en slagers

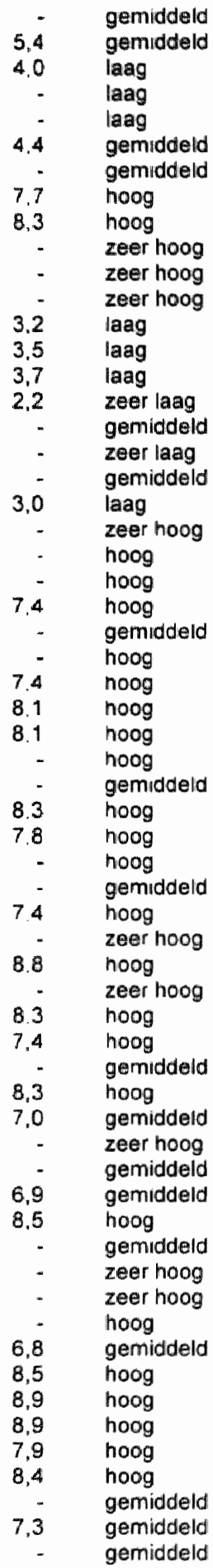


Tabol 3.4 (vervolg)

Verwachte baanopeningen per beroepsgroep (in percentage van de werkgelegenheid), Limburg, 2001

Beroepsgroep $\quad \% \quad$ typering

Asp. politieagenten, soldaten en beveiligingshulpkrachten

Politieagenten, onderofficieren en beveiligingsemployees

- zeer hoog

Politie-inspecteurs en officieren

Brandweerlieden

5,5 gemiddeld

- zeer hoog

- gemiddeld

Totalal

6,4

Bron: ROA 
Tabe/ 3.5

Verwachte arbeidsmarktinstroom van schoolverlaters per beroepsgroep (in percentage van de werkgelegenheid), Limburg, 2001

Rij-instructeurs

Zweminstructeurs

Sportinstructeurs

Bibliotheekassistenten

Grafisch ontwerpers

Agrarische hulparbeiders

Agrarische arbeiders

Agrarische vakkrachten

Landbouwmachinebestuurders en vissers

Agrarische bedrijfshoofden

Productiemedewerkers

Laboranten

Concièrges

Hoofden technische dienst

Bouwvakkers

Aannemers en installateurs

Weg-en waterbouwkundige arbeiders

Weg-en waterbouwkundige vakkrachten

Metaalarbeiders

Bankwerkers en lassers

Assembleurs

Monteurs

Elektronicamonteurs

Monteurs en controleurs elektrotechnische producten

Elektromonteurs

Grafisch productiepersoneel

Grafische vakkrachten

Mechanisch operators

Procesoperators

Confectie-arbeiders

Schoen- en kleermakers

Laders en lossers

Chauffeurs

Schippers en conducteurs

Stewards

Verplegenden en doktersassistenten

Apothekersassistenten en medisch laboranten

Kantoorhulpen. inpakkers en colporteurs

Ondersteunende administratieve hulpkrachten

Productieplanners

Receptionisten en administratieve employees

Boekhouders en secretaresses

Verzekeringsagenten

Commercieel employees

Technisch-commercieel employees.

Juridisch en fiscaal medewerkers

Administratieve transportemployees

Medisch secretaresses

Programmeurs

Activiteitenbegeleiders en medewerkers arbeidsbemiddeling

Vakkenvullers

Interieurverzorgers

Verkopers

Winkeliers

Hulpkrachten horeca en verzorging

Ziekenverzorgenden

Verzorgend personeel

Café-en snackbarhouders

\begin{tabular}{|c|c|}
\hline & \\
\hline & hoog \\
\hline & gemiddeld \\
\hline & gemiddeld \\
\hline & gemiddeld \\
\hline & zeer laag \\
\hline 4,7 & gemiddeld \\
\hline & gemiddeld \\
\hline & zeer hoog \\
\hline 2,3 & laag \\
\hline 2,9 & gemiddeld \\
\hline & gemiddeld \\
\hline & zeer laag \\
\hline & zeer laag \\
\hline 2.9 & gemiddeld \\
\hline 3,5 & $\begin{array}{l}\text { gemiddeld } \\
\text { gemiddeld }\end{array}$ \\
\hline 3.9 & gemiddeld \\
\hline 2.7 & laag \\
\hline 2.7 & laag \\
\hline 2.0 & laag \\
\hline 3.1 & gemiddeld \\
\hline - & gemiddeld \\
\hline & laag \\
\hline 39 & gemiddeld \\
\hline & gemiddeld \\
\hline 3.2 & gemiddeld \\
\hline 2.8 & laag \\
\hline 2.3 & laag \\
\hline & laag \\
\hline 1.9 & zeer laag \\
\hline 1,5 & zeer laag \\
\hline & \\
\hline 7 & zeer hoog \\
\hline 6.2 & hoog \\
\hline 6.7 & hoog \\
\hline 4.9 & gemiddeld \\
\hline & zeer hoog \\
\hline 4.0 & gemiddeld \\
\hline 4.4 & gemiddeld \\
\hline 4.1 & $\begin{array}{l}\text { gemiddeld } \\
\text { gemiddeld }\end{array}$ \\
\hline 5.1 & hoog \\
\hline 2.6 & \\
\hline & gemiddeld \\
\hline & laag \\
\hline 7,0 & hoog \\
\hline 8.9 & zeer hoog \\
\hline & zeer hoog \\
\hline 3,7 & gemiddeld \\
\hline 6,3 & hoog \\
\hline 5,0 & gemiddeld \\
\hline 5,1 & hoog \\
\hline 5,6 & hoog \\
\hline 6,3 & hoog \\
\hline & laag \\
\hline
\end{tabular}


Tabel 3.5 (vervolg)

Verwachte arbeidsmarktinstroom van schoolverlaters per beroepsgroep (in percentage van de werkgelegenheid), Limburg, 2001

Beroepsgroep $\quad \% \quad$ typering

Bedrijishoofden horeca

Bakkers en slagers

Asp. politieagenten, soldaten en beveiligingshulpkrachten

Politieagenten, onderofficieren en beveiligingsemployees

Brandweerlieden

Totaal

Bron: ROA

\section{3,8 gemiddeld \\ - gemiddeld \\ - zeer hoog \\ 6.1 hoog \\ - gemiddeld}

4,0 
Tabel 3.6

Indicator Toekornstige Arbeidsmarktpositie naar Beroep (ITAB) en Indicator Toekomstige Knelpunten in de personeelsvoorziening per Beroep (ITKB) per beroepsgroep. Limburg, 2001

Rij-instructeurs

Zweminstructeurs

Sportinstructeurs

Bibliotheekassistenten

Grafisch ontwerpers

Agrarische hulparbeiders

Agrarische arbeiders

Agrarische vakkrachten

Landbouwmachinebestuurders en vissers

Agrarische bedrijfshoofden

Productiemedewerkers

Laboranten

Conciêrges

Hoofden technische dienst

Bouwvakkers

Aannemers en installateurs

Weg-en waterbouwkundige arbeiders

Weg- en waterbouwkundige vakkrachten

Metaalarbeiders

Bankwerkers en lassers

Assembleurs

Monteurs

Elektronicamonteurs

Monteurs en controleurs elektrotechnische producten

Elektromonteurs

Grafisch productiepersoneel

Grafische vakkrachten

Mechanisch operators

Procesoperators

Confectie-arbeiders

Schoen- en kleermakers

Laders en lossers

Chauffeurs

Schippers en conducteurs

Stewards

Verplegendien en doktersassistenten

Apothekersassistenten en medisch laboranten

Kantoorhulpen, inpakkers en colporteurs

Ondersteunende administratieve nulpkrachten

Productieplanners

Receptionisten en adminıstratieve employees

Boekhouders en secretaresses

Verzekeringsagenten

Commercieel employees

Technisch-commercieel employees

Juridisch en fiscaal medewerkers

Administratieve transportemployees

Medisch secretaresses.

Programmeurs

Activiteitenbegeleiders en medewerkers arbeids bemiddeling

Vakkenvullers

Interieurverzorgers

Verkopers

Winkeliers

Hulpkrachten horeca en verzorging

Ziekenverzorgenden

Verzorgend personeel

\begin{tabular}{|c|c|c|c|}
\hline$=$ & redelijk & - & enige \\
\hline- & matig & - & vrijwel geen \\
\hline$=$ & redelijlk & - & enige \\
\hline- & redelijk & - & enige \\
\hline - & redelijk & - & enige \\
\hline$=$ & slecht & - & geen \\
\hline 0,99 & goed & 1,00 & groot \\
\hline - & slecht & - & geen \\
\hline- & goed & - & groot \\
\hline 0,96 & goed & 0,97 & groot \\
\hline 1,07 & matig & 1,07 & vrijwel geen \\
\hline- & redelijk & - & enige \\
\hline- & goed & $=$ & groot \\
\hline$=$ & goed & - & groot \\
\hline 1.01 & redelijk & 1.01 & enige \\
\hline 0,98 & goed & 0,98 & groot \\
\hline- & redelijk & - & enige \\
\hline 1,00 & goed & 1,00 & groot \\
\hline 0,99 & goed & 0,99 & groot \\
\hline 0.98 & goed & 0,98 & groot \\
\hline 0,99 & goed & 0.99 & groot \\
\hline 0.98 & goed & 0,98 & groot \\
\hline- & goed &. & groot \\
\hline - & redelijk & $\approx$ & enige \\
\hline 0.99 & goed & 0,99 & groot \\
\hline- & redelijk & 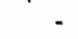 & enige \\
\hline- & goed & - & groot \\
\hline 0.98 & goed & 0.98 & groot \\
\hline 1.00 & goed & 1,00 & groot \\
\hline 0.98 & goed & 0.98 & groot \\
\hline - & matig & $=$ & vrijweil geen \\
\hline 0.95 & goed & 0,95 & groot \\
\hline 0.96 & goed & 0,96 & groot \\
\hline- & zeer goed & - & zeer groot \\
\hline- & zeer goed & - & zeer groot \\
\hline 1.04 & redelijk & 1.04 & enige \\
\hline 1.05 & redelijk & $1,0.5$ & enige \\
\hline 1.08 & matig & 1,08 & vrijwel geen \\
\hline- & slecht & - & geen \\
\hline 0.97 & goed & 0,97 & groot \\
\hline 1.01 & redelijk & 1.01 & enige \\
\hline 0,96 & goed & 0.96 & grool \\
\hline & goed & - & grool \\
\hline 0.99 & goed & 0.99 & grool \\
\hline - & goed & - & groot \\
\hline 0.96 & goed & 0.96 & grool \\
\hline$=$ & goed & - & groot \\
\hline- & goed & - & grool \\
\hline 0,99 & goed & 0,99 & groot \\
\hline 1,05 & redelijk & 1,05 & enige \\
\hline * & goed & - & grool \\
\hline 0,99 & goed & 0,99 & groot \\
\hline 1,00 & goed & 1,00 & groot \\
\hline 0,96 & goed & 0,96 & groot \\
\hline 1,01 & redelijk & 1,01 & enige \\
\hline 0,98 & goed & 0,98 & groot \\
\hline 0.99 & goed & 0,99 & groot \\
\hline
\end{tabular}


Tabel 36 (vervolg)

Indicator Toekomstige Arbeidsmarktpositie naar Beroep (ITAB) en Indicator Toekornstige Knelpunten in de personeelsvoorziening per Beroep (ITKB) per beroepsgroep. Limburg. 2001

ITAB typering ITKB typering

Cafe- en snackbarhouders

Bedrijishoofden horeca

- goed

Bakkers en slagers

Asp. politieagenten, soldaten en beveligingshuipkrachten

Politieagenten. onderofficieren en beveiligingsemployees

Brandweerlieden

0.99 goed

goed

1.01

redelijk

redelijk

goed

- groot

0,99 groot

- groot

Total

0.99

goed

0.99

groot

Bron ROA 
Tabel 3.7

Verwachte uitbreidingsvraag per opleidingstype (in percentage van de werkgelegenheid), Limburg. 2001

\section{Basisonderwijs}

VMBO theorie

VMBO landbouw en natuurlijke omgeving

VMBO bouwtechniek

VMBO installatietechniek

VMBO metaal: mechanische techniek

VMBO metaal: fijnmechanische techniek

VMBO voertuigentechniek

VMBO elektrotechniek

VMBO grafische techniek

VMBO brood en banket

VMBO transport en logistiek

VMBO administratie, handel en mode

VMBO consumptief en levensmiddelentechniek

VMBO (uiterlijke) verzorging

$\checkmark M B O$ beveiliging

HAVONWO

$M B O$ landbouw en veeteelt

MBO milieu en groene ruimte

MBO laboratorium

MBO bouw

MBO grond-, weg-en waterbouw

MBO installatietechniek

MBO werktuigbouw en mechanısche techniek

MBO fijnmechanische techniek

MBO motorvoertuigentechniek

MBO vliegtuigtechniek

MBO operationele techniek

MBO elektrotechniek

MBO grafische techniek

MBO procestechniek

MBO brood en banket

MBO levensmiddelentechniek/vleesverwerking

$M B O$ vervoer en logistiek

MBO dokters-. tandarts- en dierenartsassistent

MBO apothekersassistent

$M B O$ verpleging

MBO gezondheidstechniek

MBO sociaal-cultureel

$M B O$ verzorging

MBO uiterlijke verzorging

MBO horeca

MBO beweging en therapie

$M B O$ administratie

MBO handel

MBO secretariaat

MBO toerisme en recreatie

$M B O$ bedrijfskunde

MBO automatisering

$M B O$ geld, bank en belastingen

$M B O$ verzekeringswezen

MBO openbare orde en veiligheid

HBO lerarenopleiding basisonderwijs

$\mathrm{HBO}$ lerarenopleiding talen

$\mathrm{HBO}$ lerarenopleiding natuur en techniek

HBO lerarenopleiding economie en maatschappij

HBO lerarenopleiding lichamelijke opvoeding

$\mathrm{HBO}$ lerarenopleiding medisch en verzorging

HBO lerarenopleiding expressie

HBO tolk en vertaler

$\mathrm{HBO}$ landbouw en veeteelt
$-3,1 \quad$ zeer laag

1,3 laag

-1.1 zeer laag

-0.7 zeer laag

- laag

$-0,8$ zeer laag

- laag

$-0.9 \quad z e e r$ laag

$-0,9 \quad$ zeer laag

zeer laag

zeer laag

zeer laag

zeer laag

$0.0 \quad$ laag

$0,3 \quad$ laag

- zeer laag

4,9 noog

2.6 gemiddeld

gemiddald

lang

2.9 gemiddeld

- hoog

2.3 laag

2.3 laag

- laag

2.4 gemiddeld

- zeer hoog

- hoog

2,8 gemiddeld

- gemiddeld

1.9 laag

- gemiddeld

- laag

$4,1 \quad$ hoog

- gemiddeld

- gemiddeld

2.6 gemiddeld

- gemiddeld

5,0 hoog

2,6 gemiddeld

2.7 gemiddeld

2,5 gemiddeld

- gemiddeld

2.5 gemiddeid

2.5 gemiddeld

2.9 gemiddeld

- gemiddeld

2.5 gemiddeld

2,3 laag

2,4 gemiddeld

- gemiddeld

3,0 gemiddeld

2,5 gemiddeld

- gemidideld

- gemiddeld

- gemiddeld

- gemiddeld

- laag

- gemiddeld

- hoog

- gemiddeld 
Tabel 3.7 (vervolg)

Verwachte uitbreidingsvraag per opleidingstype (in percentage van de werkgelegenheld). Limburg, 2001

Opleidingstype $\quad \%$ typerng

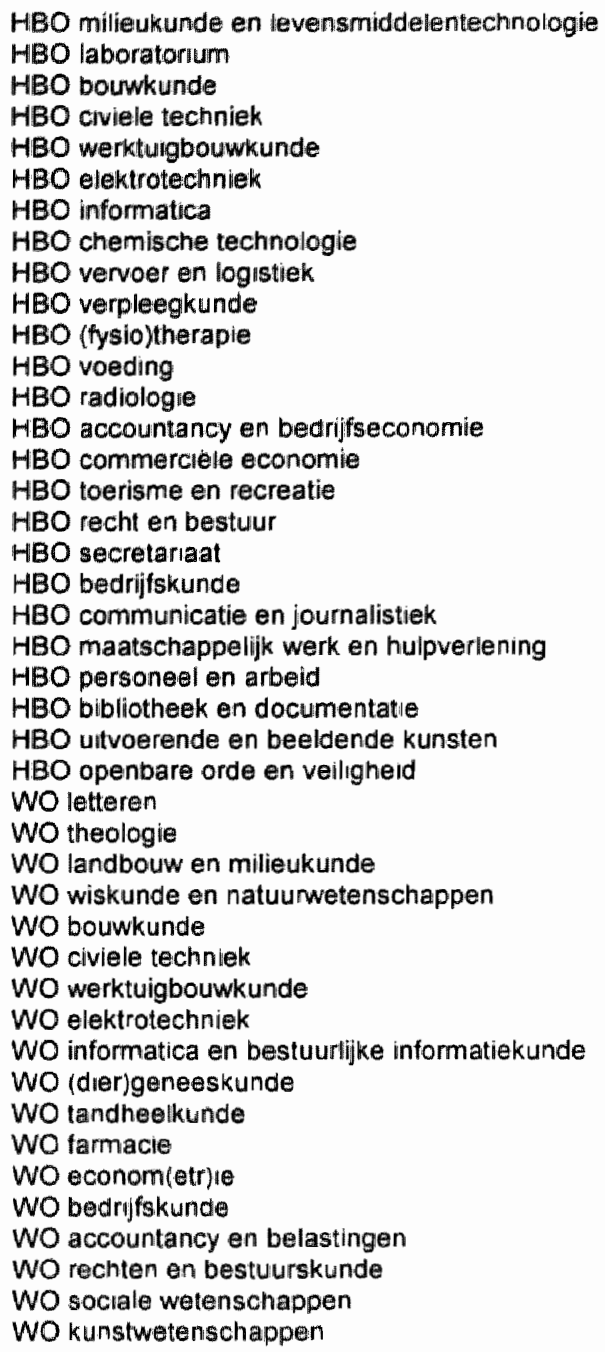

Totaal

\begin{tabular}{|c|c|}
\hline & gemıddeld \\
\hline 3.1 & gemiddeld \\
\hline- & gemiddeld \\
\hline & gemiddeld \\
\hline 2,0 & laag \\
\hline 1.9 & laag \\
\hline 3.8 & hoog \\
\hline & laag \\
\hline & gemiddeld \\
\hline 4,6 & hoog \\
\hline .4 & hoog \\
\hline & gemiddeld \\
\hline & hoog \\
\hline $\begin{array}{l}5,3 \\
47\end{array}$ & zeer hoog \\
\hline 4.7 & hoog \\
\hline - & zeer hoog \\
\hline - & hoog \\
\hline 1 & hoog \\
\hline 4.4 & hoog \\
\hline & zeer hoog \\
\hline 2,4 & gemiddeld \\
\hline & yemiddeld \\
\hline & emiddelo \\
\hline 2.9 & gemıddeld \\
\hline & gemiddeld \\
\hline- & zeer hoog \\
\hline- & zeer noog \\
\hline & zeer hoog \\
\hline 3.6 & gemiddeld \\
\hline- & laag \\
\hline - & zeer hoog \\
\hline - & laag \\
\hline- & laag \\
\hline 4,0 & hoog \\
\hline & gemiddeld \\
\hline ـ & gemiddeld \\
\hline 6.7 & zeer hoog \\
\hline & hoog \\
\hline & er noo \\
\hline 5.0 & hoog \\
\hline & zeer hoog \\
\hline 2 & \\
\hline
\end{tabular}

Bron ROA 
Tabel 3.8

Verwachte netto vervangingsvraag per opleidingstype (in percentage wan de werkgelegenheid), Limburg. 2001

Basisonderwijs

VMBO theorie

VMBO landbouw en natuurlijke omgeving

VMBO bouwtechniek

VMBO installatietechniek

VMBO metaal: mechanische techniek

VMBO metaal: fijnmechanische techniek

VMBO voertuigentechniek

VMBO elektrotechniek

VMBO grafische techniek

VMBO brood en banket

VMBO transport en logistiek

VMBO administratie, handel en mode

VMBO consumptief en levensmiddelentechniek

VMBO (uiterlijke) verzorging

VMBO beveiliging

HAVOMWO

$M B O$ landbouw en veeteelt

MBO milieu en groene ruimte

$M B O$ laboratorium

MBO bouw

MBO grond-, weg-en waterbouw

MBO installatietechniek

MBO werktuigbouw en mechanische techniek

MBO fijnmechanische techniek

MBO motorvoertuigentechniek

MBO vliegtuigtechniek

MBO operationele techniek

MBO elektrotechniek

MBO grafische techniek

MBO procestechniek

MBO brood en banket

MBO levensmididelentechniek/vleesverwerking

MBO vervoer en logistiek

MBO dokters-, tandarts- en dierenartsassistent

MBO apothekersassistent

$M B O$ verpleging

MBO gezondheidstechniek

MBO sociaal-cultureel

$M B O$ verzorging

MBO uiterlijke verzorging

MBO horeca

MBO beweging en therapie

MBO administratie

$M B O$ hande

MBO secretariaat

MBO toerisme en recreatie

MBO bedriffskunde

MBO automatisering

MBO geld, bank en belastingen

$M B O$ verzekeringswezen

MBO openbare orde en veiligheid

HBO lerarenopleiding basisonderwijs

HBO lerarenopleiding talen

HBO lerarenopleiding natuur en techniek

HBO lerarenopleiding economie en maatschappij

HBO lerarenopleiding lichamelijke opvoeding

HBO lerarenopleiding medisch en verzorging

HBO lerarenopleiding expressie

$\mathrm{HBO}$ tolk en vertaler

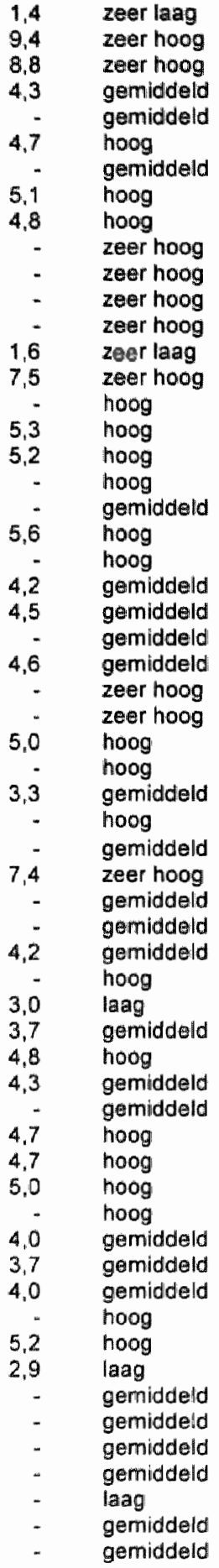


Tabel 3.8 (vervolg)

Verwachte netto vervangingsvraag per opleidingstype (in percentage van de werkgelegenheid). Limburg, 2001

Opleidingstype

$\% \quad$ typering

$\mathrm{HBO}$ landbouw en veeteelt

HBO milieukunde en levensmiddelentechnologie

HBO laboratorium

HBO bouwkunde

$\mathrm{HBO}$ civiele techniek

$\mathrm{HBO}$ werktuigbouwkunde

HBO elektrotechniek

$\mathrm{HBO}$ informatica

HBO chemische technologie

$\mathrm{HBO}$ vervoer en logistiek

$\mathrm{HBO}$ verpleegkunde

$H B O$ (fysio)theraple

$\mathrm{HBO}$ voeding

HBO radiologie

$\mathrm{HBO}$ accountancy en bedrifíseconomie

HBO commerciele economie

$\mathrm{HBO}$ toerisme en recreatie

HBO recht en bestuur

$\mathrm{HBO}$ secretariaat

HBO bedrijfskunde

HBO communicatie en journalistiek

HBO maatschappelijk werk en hulpverlening

HBO personeel en arbeld

HBO bibliotheek en documentatie

HBO uitvoerende en beeldende kunsten

$\mathrm{HBO}$ openbare orde en veiligheid

WO letteren

WO theologie

WO landbouw en milieukunde

WO wiskunde en natuurwetenschappen

WO bouwkunde

WO civiele techniek

WO werktuigbouwkunde

WO elektrotechniek

WO informatica en bestuurlijke informatiekunde

WO (dier)geneeskunde

WO tandheekunde

Wo farmacie

WO econom(etr)ie

WO bedriffskunde

WO accountancy en beiastingen

WO rechten en bestuurskunde

WO sociale wetenschappen

WO kunstwetenschappen

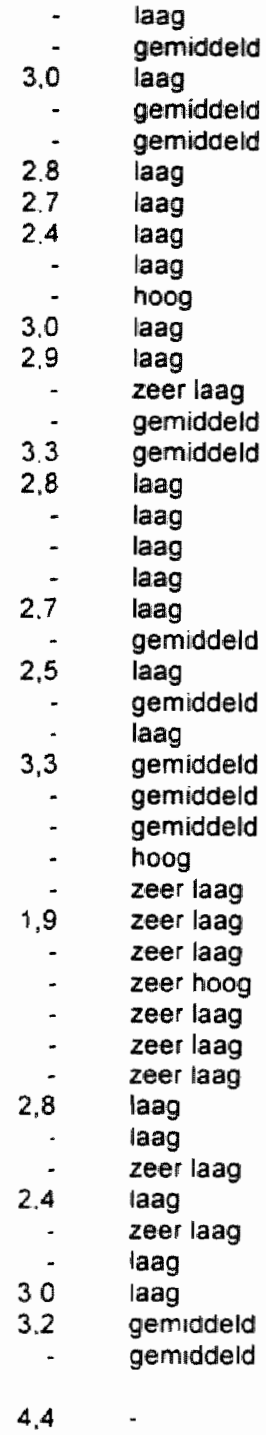

Totaal

4.4

Bron: ROA 


$\begin{array}{lll}\text { Opleidingstype } & \% & \text { typering }\end{array}$

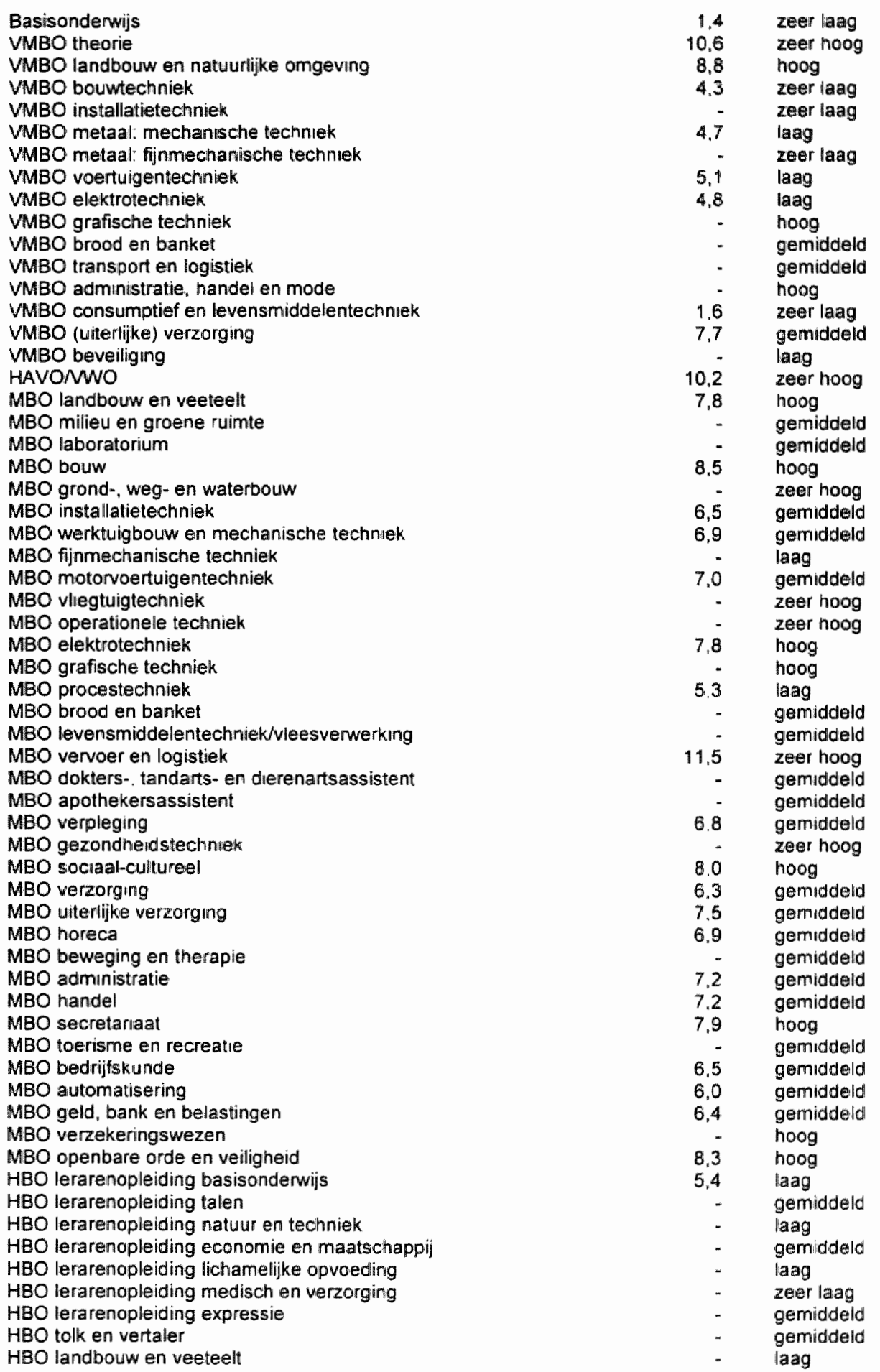


HBO milieukunde en levensmiddelentechnologie HBO laboratorium

HBO bouwkunde

HBO clwele techniek

HBO werktuigbouwkunde

$\mathrm{HBO}$ elektrotechniek

$\mathrm{HBO}$ informatica

HBO chemische technologie

$H B O$ vervoer en logistiek

$\mathrm{HBO}$ verpleegkunde

$\mathrm{HBO}$ (fysio)therapie

$H B O$ voeding

$\mathrm{HBO}$ radiologie

$\mathrm{HBO}$ accountancy en bedrijfseconomie

$\mathrm{HBO}$ commerciele economie

HBO toerisme en recreatie

$\mathrm{HBO}$ recht en bestuur

$\mathrm{HBO}$ secretariaat

HBO bedriffskunde

HBO communicatie en journal Istrek

HBO maatschappelijk werk en hulpverlening

HBO personeel en arbeid

$\mathrm{HBO}$ bibliotheek en documentatie

HBO sociaal-cultureel overig

$\mathrm{HBO}$ uitvoerende en beeldende kunsten

$\mathrm{HBO}$ openbare orde en veiligheid

WO letteren

WO thealogie

WO landbouw en milieukunde

WO wiskunde en natuurwetenschappen

WO bouwkunde

WO civiele techniek

WO werktuigbouwkunde

WO elektrotechniek

WO informatica en bestuurlijke intormatiekunde

WO (dier)geneeskunde

WO tandheelkunde

WO farmacie

WO econom(etr)ie

WO bedrijtskunde

WO accountancy en belastingen

WO rechten en bestuurskunde

WO sociale wetenschappen

WO kunstwetenschappen

Totaal

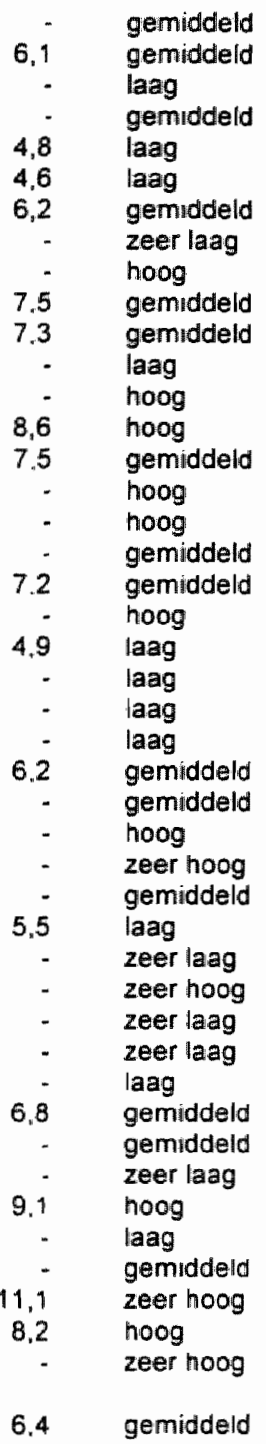

Bron ROA 
Tabel 3.10

Verwachte arbeidsmarktinstroom van schoolverlaters per opleidingstype (in percentage van de werkgelegenheid), Limburg, 2001

Opleidingstype

Basisonderwijs

VMBO theorie

VMBO landbouw en natuurlijke omgeving

VMBO bouwtechniek

VMBO installatietechniek

VMBO metaal mechanische techniek

VMBO metaal: fijnmechanische techniek

VMBO voertulgentechniek

VMBO elektrotechniek

VMBO grafische techniek

VMBO brood en banket

VMBO transport en logistiek

VMBO administratie, handel en mode

VMBO consumptief en levensmiddelentechniek

VMBO (uiterlijke) verzorging

VMBO beveiliging

HAVONWO

MBO landbouw en veeteelt

MBO milieu en groene ruimte

MBO laboratorium

MBO bouw

MBO grond-, weg- en waterbouw

MBO installatietechniek

MBO werktuigbouw en mechanısche techniek

MBO fijnmechanische techniek

MBO motorvoertuigentechniek

MBO vlıegtuigtechnıek

MBO operationele techniek

MBO elektrotechniek

MBO grafische techniek

MBO procestechniek

MBO brood en banket

MBO levensmiddelentechniek/vleesverwerking

MBO vervoer en logistiek

MBO dokters-, tandarts- en dierenartsassistent

MBO apothekersassistent

$M B O$ verpleging

MBO gezondheidstechniek

MBO sociaal-cultureel

$M B O$ verzorging

$\mathrm{MBO}$ uiterlijke verzorging

MBO horeca

MBO beweging en therapıe

MBO administratie

MBO handel

MBO secretariaat

MBO toerisme en recreatie

MBO bedrutskunde

MBO automatisering

MBO geld, bank en belastingen

$M B O$ verzekeringswezen

MBO openbare orde en veiligheid

Totaal
$\% \quad$ typering

\section{7}

5,2

3.1

2,5

2.5

3,7

3,4

- hoog

- noog

- hoog

- gemidalela

1,7 zeer laag

3,4 gemiddeld

- gemiddeld

9.2 zeer hoog

3.5 gemiddeld

gemiddeld

- gemiddeld

3.2 gemiddeld

- gemiddeld

2.7 laag

2.6 laag

- zeer laag

3.1 laag

- zeer hoog

- hoog

3,5 gemiddeld

- gemiddeld

2,2 laag

- gemiddeld

- laag

4,8 hoog

- hoog

- gemiddeld

3.9 gemiddeld

- hoog

7.9 zeer hoog

4.3 gemiddeld

5.9 zeer hoog

4.6 gemiddeld

- hoog

3.7 gemiddeld

3.4 gemiddeld

4.6 gemiddeld

- zeer hoog

2.2 laag

2,9 laag

$1,6 \quad$ zeer laag

- gemiddeld

2,5 laag

4,0

Bron: ROA 
Tabel 3.19

Indicator Toekomstige Arbeidsmarktperspectieven (ITA) en Indicator Toekomstige Knelpunten in de Personeelsvoorziening (ITKP) per opleidingstype, Lumburg. 2001

Opleidingstype ITA typering ITKP typering

\begin{tabular}{|c|c|c|c|c|}
\hline $\begin{array}{l}\text { Basisonderwijs } \\
\text { VMBO theorie }\end{array}$ & $\begin{array}{l}1.03 \\
0.99\end{array}$ & $\begin{array}{l}\text { redelijk } \\
\text { goed }\end{array}$ & $\begin{array}{l}1.07 \\
0.99\end{array}$ & $\begin{array}{l}\text { vrijwel geen } \\
\text { groot }\end{array}$ \\
\hline VMBO landbouw en natuurlijke orngeving & 0.97 & goed & 0,98 & groot \\
\hline VMBO bouwtechniek & 1,06 & matrg & 1.07 & vrijwel geen \\
\hline VMBO installatietechniek & - & goed & - & groot \\
\hline VMBO metaal: mechanische techniek & 0,98 & goed & 0.99 & groot \\
\hline VMBO metaal; fijnmechanische techniek & . & goed & - & groot \\
\hline VMBO voertuigentechniek & 0.99 & goed & 1.00 & groat \\
\hline VMBO elektrotechniek & 0.99 & goed & 0.99 & groot \\
\hline VMBO grafische techniek & - & goed & - & groot \\
\hline VMBO brood en banket & - & goed & - & groot \\
\hline VMBO transport en logistiek & - & redelijk & - & enige \\
\hline VMBO administratie, handel en mode & $\cdot$ & slecht & - & geen \\
\hline VMBO techniek overig & 1.04 & redelijk & 1,08 & vrijwel geen \\
\hline VMBO consumptief en levensmiddelentechniek & 1.00 & goed & 1,00 & groot \\
\hline VMBO (uiterlijke) verzarging & 0.99 & goed & 0,99 & groot \\
\hline VMBO beveiliging & $\cdot$ & matig & - & vrijwel geen \\
\hline VMBO overig & $\cdot$ & slecht & - & geen \\
\hline HAVONWO & 1.02 & redelijk & 1.02 & enige \\
\hline MBO landbouw en veeteeit & 0.97 & goed & 0.97 & groot \\
\hline MBO milieu en groene rumte & - & goed & - & groot \\
\hline MBO laboratorium & - & goed & - & groot \\
\hline MBO bouw & 0.96 & goed & 0.96 & groot \\
\hline MBO grond-, weg- en waterbouw & - & goed & - & groot \\
\hline MBO installatietechniek & 0.97 & goed & 0,97 & groot \\
\hline MBO werktuigbouw en mechanische techniek & 1.00 & goed & 1,00 & groot \\
\hline MBO filnmechanische techniek & - & goed & - & groot \\
\hline MBO motorvoertuigentechniek & 0.96 & goed & 0.96 & groot \\
\hline MBO vliegtuiglechniek & - & goed & - & groot \\
\hline MBO operationele techniek & - & goed & - & groot \\
\hline MBO viektrotechniek & 0.96 & goed & 0,96 & groot \\
\hline MBO grafische techniek & - & goed & - & groot \\
\hline MBO procestechniek & 0,98 & goed & 0.98 & groot \\
\hline MBO brood en banket & - & goed & - & groot \\
\hline MBO levensmiddelentechniek/vleesverwerking & - & goed & - & groot \\
\hline MBO vervoer en logistiek & 0.97 & goed & 0,97 & groot \\
\hline MBO technlek overig & 0,96 & goed & 0.96 & groot \\
\hline MBO dokters- tandarts-en dierenartsassistent & - & goed & * & groot \\
\hline MBO apothekersassistent & - & goed & - & grooll \\
\hline MBO verpleging & 0,98 & goed & 0,98 & groot \\
\hline MBO gezondheidstechnek & - & goed & - & groat \\
\hline MBO sociaal-culturael & 1.03 & redelijk & 1.03 & enige \\
\hline MBO verzorging & 0.98 & goed & 0,98 & groot \\
\hline MBO uiterlijke verzorging & 1,00 & goed & 1.00 & groot \\
\hline MBO noreca & 0,99 & goed & 0.99 & groot \\
\hline MBO beweging en therapie & - & redelijk & - & enige \\
\hline MBO administratie & 0.98 & goed & 0,98 & groot \\
\hline MBO handel & 0,97 & goed & 0,97 & groot \\
\hline MBO secretariaat & 0,97 & goed & 0,97 & groot \\
\hline MBO toerisme en recreatie & - & redelijk & - & enige \\
\hline MBO bedriffskunde & 0,96 & goed & 0,96 & groot \\
\hline MBO automatisering & 0.97 & goed & 0,97 & groot \\
\hline MBO geld, bank en belastingen & 0,96 & goed & 0,96 & groot \\
\hline MBO verzekeringswezen & - & goed & * & groot \\
\hline MBO openbare orde en veiligheid & 0,95 & goed & 0,95 & groot \\
\hline Totaal & 0,99 & goed & 0,99 & groot \\
\hline
\end{tabular}

Bron: ROA

N.B. Het totaal heeft betrekking op alle opleidingstypen, dus inclusief $\mathrm{HBO}$ en WO 


\section{De Limburgse arbeidsmarkt tot 2004}

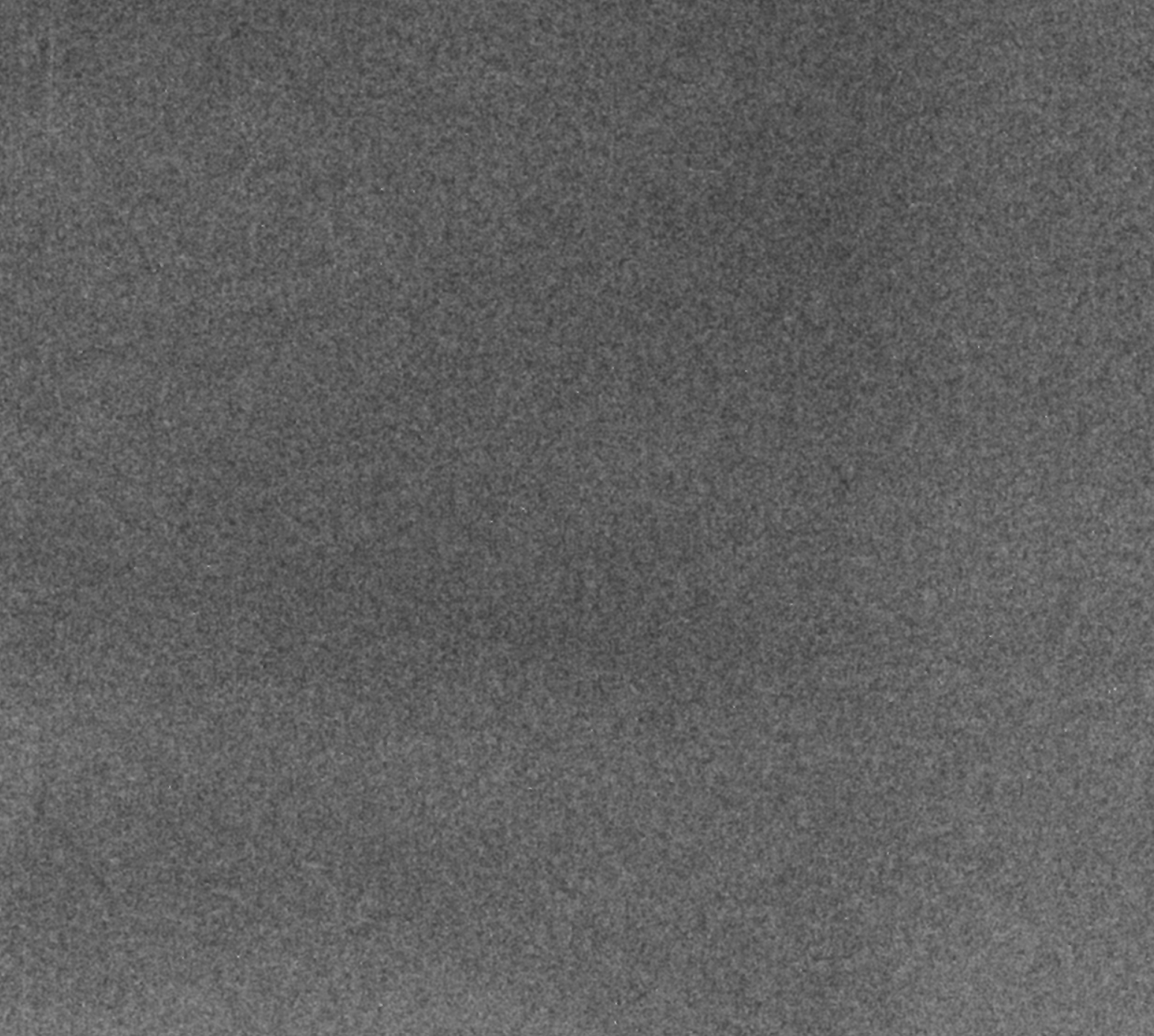

10.

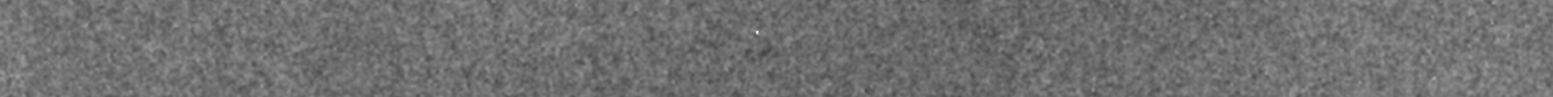



Tabel 4.1

Verwachte uitbreidingsvraag per bedrjifssector, Limburg, 1999-2004 (percentage van de werkgelegenheid)

$\begin{array}{lll}\text { Bedrijfssector } & \% & \text { typering }\end{array}$

Landbouw en vissery

gemidideld

Voeding

Chemie

gemidideld

Metaal

Overige industrie

erg laag

erg laag

erg laag

Energie

erg laag

Bouw en onroerend goed

erg laag

Handel

gemiddeld

Transport en communicatie

erg laag

erg laag

Horeca, reparatie en zakelijke dienstverlenıng

erg hoog

Kwartaire diensten

gemiddeld

Overheid en onderwijs

erg laag

Totaal

3

Bron: ROATNO/Inro 
Leraar basisonderwijs

Docenten exacte, medische en verzorgende vakken (2e graads) Docenten exacte, medische en verzorgende vakken (1e graads) Docenten landbouw en techniek (2e graads)

Docenten economisch-administratieve vakken (2e graads)

Docenten economisch-administratieve vakken (1e graads)

Docenten talen en expressie

Docenten letteren (1e graads)

Docenten sociale vakken (2e graads)

Docenten sociale vakken (1e graads)

Docenten ze graads zonder specialisatie

Onderwijskundig medewerkers

Onderwijskundigen en pedagogen

Rijj-instructeurs

Zweminstructeurs

Sportinstructeurs

Tolken, vertalers en schrijvers

Bibliotheekassistenten

Bibliothecarissen

Grafisch ontwerpers.

Kunstenaars

Geestelijken

Journalisten

Taalkundigen

Agrarische hulparbeiders

Agrarische arbeiders

Agrarische vakkrachten

Milieuhygienisten en agrarisch vertegenwoordigers

Landbouwmachinebestuurders en vissers

Agrarische bedriffshoofden

Productiemedewerkers

Laboranten

Technisch analisten

Natuurwetenschappers

Concierges

Hoofden technische dienst

Werktuigbouwkundigen

Bouwvakkers

Aannemers en installateurs

Architecten en bouwkundig projectleiders

Weg- en waterbouwkundigen

Wog-en waterbouwkundige arbeiders

Weg-en waterbouwkundige vakkraenten

Weg- en waterbouwkundig ontwerpers en projectleiders

Metaallarbeiders

Bankwerkers en lassers

Bedrijfshoofden metaalbewerking

Assembleurs

Monteurs

Werktuigbouwkundig ontwerpers en hoofden technische dienst

Elektronicamonteurs

Monteurs en controleurs elektrotechnische producten

Elektromonteurs

Elektrotechnisch ontwerpers en bedrijfshoofden

Elektrotechnici

Grafisch productiepersoneel

Grafische vakkrachten

Mechanisch operators

Procesoperators

Procestechnologen

Materiaalkundigen gemiddeld

laag

gemiddeld

gemiddeld

laag

gemiddeld

laag

gemiddeld

laag

gemiddeld

gemiddeld

hoog

hoog

gemiddeld

gemiddeld

gemiddeld

gemiddeld

laag

gemiddeld

gemiddeld

gemiddeld

hoog

gemiddela

gemiddeld

gemiddeld

laag

gemiddeld

laag

laag

gemiddeld

gemiddeld

erg laag

erg laag

laag

erg laag

laag

erg laag

erg laag

laag

laag

erg laag

erg laag

laag

erg laag

erg laag

laag

laag

erg laag

erg laag

erg laag

laag

erg laag

laag

erg laag

erg laag

erg laag

laag

erg laag

erg laag

erg laag

erg laag 
Tabel 4.2 (vervolg)

Verwachte uitbreidingsvraag per beroepsgroep, Limburg, 1999-2004 (percentage van de werkgelegenheid)

Beroepsgroep $\quad \% \quad$ typering

Confectie-arbeiders

Schoen- en kleermakers

$-32$

erg laag

Laders en lossers

Chauffeurs

Schippers en conducteurs

Vliegers, scheepskapiteins en leidinggevenden transport

Stewards

Verpleeghulpen en leerling-verpleegkundigen

Verplegenden en doktersassistenten

Therapeuten en verpleegkundigen

Artsen

Apothekersassistenten en medisch laboranten

Medisch analisten

Apothekers

Afdelingshoofden zorginstelling

Kantoorhulpen, inpakkers en colporteurs

Ondersteunende administratieve hulpkrachten

Bedrijfshoofden

Economen

Productieplanners

Organisatie-adviseurs

Organisatiedeskundigen

Receptionisten en administratieve employés

Boekhouders en secretaresses

Assistent accountants

Accountants

Verzekeringsagenten

Commercieel employés

Commercieel medewerkers

Technisch-commercieel employés

Technisch-bedrijfskundig medewerkers

Juridisch en fiscaal medewerkers

Juridisch, bestuurlijk medewerkers

Juristen

Administratieve transportemployès

Leidinggevenden

Managers

Medisch secretaresses

Programmeurs

Systeemanalisten

Informatici

Technisch systeemanalisten

Activiteitenbegeleiders en medewerkers arbeidsbemiddeling

Medewerkers sociaal-cultureel werk en personeel en arbeid

Hoofden sociaal-cultureel werk en personeel en arbeid

Sociaal-wetenschappelijk medewerkers

Sociaal-wetenschappelijk onderzoekers

Interieurverzorgers

Verkopers

laag

1

$-7$

gemiddeld

gemiddeld

erg laag

gemiddeld

hoog

gemiddeld

gemiddeld

gemiddeld

gemiddeld

gemiddeld

gemiddeld

gemiddeld

gemiddeld

gemiddeld

laag

erg hoog

laag

erg hoog

erg hoog

hoog

erg hoog

gemiddeld

erg hoog

hoog

erg hoog

gemiddeld

erg hoog

gemiddeld

hoog

gemiddeld

gemiddeld

gemiddeld

laag

gemiddeld

gemiddeld

hoog

gemiddeld

erg hoog

gemiddeld

erg laag

hoog

gemiddeld

hoog

gemiddeld

hoog

gemiddeld

erg hoog

Winkeliers

gemiddeld

Hulpkrachten horeca en verzorging

laag

Ziekenverzorgenden

Verzorgend personeel

erg hoog

gemiddeld

Café- en snackbarhouders

laag

Bedrijfshoofden horeca

Bakkers en slagers

Aspirant politieagenten, soldaten en beveiligingshulpkrachten

gemiddeld

erg laag

gemiddeld 
Tabel 4.2 (vervolg)

Verwachte utbreidingsvraag per beroepsgroep, Limburg. 1999-2004 (percentage van de werkgelegenheid)

Beroepsgroep $\quad \% \quad$ typering

Politieagenten, onderofficieren en bevelligingsemployés

Politie-inspecteurs en officieren

Brandweerljeden

gemiddeld

gemiddeld

Totaal

3

Bron: ROA 
Tabel 4.3

Verwachte (netto) vervangingsvraag per beroepsgroep. Limburg. 1999-2004 (percentage van de werkgelegenheid)

Leraar basisonderwijs

Docenten exacte, medische en verzorgende vakken ( $2 e$ graads)

Docenten exacte, medische en verzorgende vakken (1e graads)

Docenten landbouw en techniek (2e graads)

Docenten economisch-administratieve vakken (2e graads)

Docenten economisch-administratieve vakken (1e graads)

Docenten talen en expressie

Docenten letteren ( 1 e graads)

Docenten sociale vakken (2e graads)

Docenten sociale vakken (1e graads)

Docenten 2 e graads zonder specialisatie

Onderwijskundig medewerkers

Onderwijskundigen en pedagogem

Rij-instructeurs

Zweminstructeurs

Sportinstructeurs

Tolken, vertalers en schrijvers

Bibliotheekassistenten

Bibliothecarissen

Grafisch ontwerpers

Kunstenaars

Geestelijken

Journalisten

Taalkundigen

Agrarische hulparbeiders

Agrarische arbeiders

Agrarische vakkrachten

Milieuhygienisten en agrarisch vertegenwoordigers

Landbouwmachinebestuurders en vissers

Agrarische bedrijfshoofden

Productiemedewerkers

Laboranten

Technisch analisten

Natuurwetenschappers

Conciërges

Hoofden technische dienst

Werktuigbouwkundigen

Bouwwakkers

Aannemers en installateurs

Architecten en bouwkundig projectleiders

Weg-en waterbouwkundigen

Weg-en waterbouwkundige arbeiders

Weg-en waterbouwkundige vakkrachten

Weg- en waterbouwkundig ontwerpers en projectleiders

Metaalarbeiders

Bankwerkers en lassers

Bedrijfshoofden metaalbewerking

Assembleurs

Monteurs

Werktuigbouwkundig ontwerpers en hoofden technische dienst

Elektronicamonteurs

Monteurs en conitroleurs elektrotechnische producten

Elektromonteurs

Elektrotechnisch ontwerpers en bedrijfshoofden

Elektrotechnic

Grafisch productiepersoneel

Grafische vakkrachten

Mechanisch operators

Procesoperators

Procestechnologen
19

gemiddeld

hoog

hoog

erg hoog

hoog

gemiddeld

hoog

hoog

hoog

hoog

hoog

hoog

gemiddeld

hoog

gemiddeld

gemiddeld

gemiddeld

gemiddela

hoog

erg laag

gemiddeld

gemiddeld

laag

gemiddeld

laag

gemiddeld

laag

gemiddeld

gemiddeld

gemiddeld

laag

gemiddeld

gemiddeld

gemiddeld

hoog

gemiddeld

gemiddeld

gemiddeld

gemuddeld

gemiddeld

noog

gem:ddeld

gemiddeld

laag

gemiddeld

gemuddeld

hoog

gemiddeld

gemiddeld

hoog

gemiddeld

gemiddeld

gemiddeld

hoog

laag

gemiddeld

gemiddeld

gemiddeld

laag

hoog 
Verwachte (netio) vervangingswraag per beroepsgroep. Limburg. 1999-2004 (percentage van de werkgelegenneid)

Materiaalkundigen

gemiddeld

Confectie-arbeiders

hoog

Schoen-en kleermakers

hoog

Laders en lossers

Chauffeurs

Schippers en conducteurs

Vliegers, scheepskapiteins en leidinggevenden transport

Stewards

Verpleeghulpen en leerling-verpleegkundigen

Verplegenden en doktersassistenten

Therapeuten en verpleegkundigen

erg laag

gemidideld

gemiddeld

laag

laag

laag

Artsen

Apothekersassistenten en medisch laboranten

hoog

gemiddeld

gemiddeld

Medisch analisten

Apothekers

Afdelingshoofden zorginstelling

Kantoorhulpen, inpakkers en calparteurs

Ondersteunende administratieve hulpkrachten

Bedrijfshoofden

Economen

Productieplanners

Organisatie-adviseurs

Organisatiedeskundigen

Receptionisten en administratieve employés

gemiddeld

gemiddeld

laag

erg hoog

erg laag

hoog

gemiddeld

laag

erg laag

erg laag

laag

hoog

Boekhouders en secretaresses

laag

laag

laag

Accountants

Verzekeringsagenten

Commercieel employès

Commercieel medewerkers

Technisch-commercieel employés

Technisch-bedrijfskundig medewerkers

Juridisch en fiscaal medewerkers

gemidideld

laag

laag

gemiddeld

gemiddeld

Juridisch. bestuurlijk medewerkers

gemiddeld

hoog

Juristen

Administratieve transportemployés

laag

Leidinggevenden

gemiddeld

gemiddeld

Managers

gemiddeld

Medisch secrelaresses

Programmeurs

Systeemanalisten

gemiddeld

erg laag

erg laag

erg laag

erg laag

Technısch systeemanalisten

Activiteitenbegeleiders on medewerkers arbeidsbemiddeling

erg laag

Medewerkers sociaal-cultureel werk en personeel en arbeid

gemiddeld

gemiddeld

Hoofden sociaal-cultureel werk en personeel en arbeid

hoog

Sociaal-wetenschappelijk medewerkers

Sociaal-wetenschappelijk onderzoekers

laag

Interieurverzorgers

gemiddeld

Verkopers

gemiddeld

gemiddeld

Hulpkrachten horeca en verzorging

hoog

laag

Ziekenverzorgenden

gemiddeld

Verzorgend personeel

hoog

Café-en snackbarhouders

gemiddeld

Bedrijfshoofden horeca

gemiddeld

Bakkers en slagers

Aspirant politieagenten, soldaten en beveiligingshulpkrachten

gemiddeld 
Tabel 4.3 (vervolg)

Verwachte (netto) vervangingsvraag per beroepsgroep, Limburg, 1999-2004 (percentage van de werkgelegenheid)

\section{Beroepsgroep}

Politieagenten, onderofficieren en beveiligingsemployés

Politie-inspecteurs en officieren

Brandweerlieden

Totaal

Bron: ROA
$\%$

typering

18

gemiddeld

laag

hoog 
Verwachte baanopeningen per beroepsgroep. Limburg. 1999-2004 (percentage van de werkgelegenheid)

Onderwijskundigen en pedagogen

Rij-instructeurs

\section{Zweminstructeurs}

Sportinstructeurs

Tolken, vertalers en schrijvers

Bibliotheekassistenten

Bibliothecarissen

Grafisch ontwerpers

Kunstenaars

Geestelijken

Joumalisten

Taalkundigen

Agrarische hulparbeiders

Agrarische arbeiders

Agrarische vakkrachten

Millieuhygiênisten en agrarısch vertegenwoordigers

gemiddeld

gemiddeld

gemideld

gemidideld

gemiddeld

gemiddeld

hoog

gemiddeld

gemiddeld

gemiddeld

gemiddeld

gemiddeld

gemiddeld

gemiddeld

laag

gemiddeld

gemiddeld

laag

gemiddeld

laag

gemiddeld

laag

gemiddeld

gemiddeld

Landbouwmachinebestuurders en vissers

Agrarísche bedrijfshoofden

gemiddeld

Productiemedewerkers

laag

Laboranten

Technisch analisten

Natuurwetenschappers

Conciërges

Hoofden technische diens!

Werktuigbouwkundigen

Bouwvakkers

Aannemers en installateurs

Architecten en bouwkundig projectleiders

Weg- en waterbouwkundigen

Wog- en waterbouwkundige arbeiders

Weg-en waterbouwkundige vakkrachten

Weg-en waterbouwkundig ontwerpers en projectleiders

Metaalarbeiders

Bankwerkers en lassers

gemiddeld

gemidideld

gemiddeld

gemiddeld

gemiddeld

gemiddeld

gemiddeld

gemiddeld

gemiddeld

gemiddelo

gemiddeld

gemiddeld

laag

gemiddeld

gemiddeld

gemiddeld

gemiddeld

Assembleurs

gemiddeld

gemiddeld

gemiddeld

gemiddeld

Elektronicamonteurs

Monteurs en controleurs elektrotechnische producten

gemiddeld

gemiddeld

Elaktrotechnisch ontwerpers en bedrijfshoofden

laag

Elektrotechnici

Grafisch productiepersoneel

Grafische vakkrachten

gemiddeld

gemiddeld

Mechanisch operators

gemiddeld

erg laag

Procesoperators

Procestechnologen

gemiddeld

Materiaalkundigen

gemiddeid 
Tabel 4.4 (vervolg)

Verwachte baanopeningen per beroepsgroep. Limburg, 1999-2004 (percentage van de werkgelegenheid)

Beroepsgroep $\quad \% \quad$ typering

Confectie-arbeiders

Schoen- en kleermakers

Laders en lossers

Chauffeurs

Schippers en conducteurs

Vliegers, scheepskapiteins en leidinggevenden transport

Stewards

Verpleeghulpen en leerling-verpleegkundigen

Verplegenden en doktersassistenten

Therapeuten en verpleegkundigen

Artsen

Apothekersassistenten en medisch laboranten

Medisch analisten

Apothekers

Afdelingshoofden zorginstelling

Kantoorhulpen, inpakkers en colporteurs

Ondersteunende administratieve hulpkrachten

Bedrijfshoofden

Economen

Productieplanners

Organisatie-adviseurs

Organisatiedeskundigen

Receptionisten en administratieve employes

Boekhouders en secretaresses

Assistent accountants

Accountants

Verzekeringsagenten

Commercieel employés

Commercieel medewerkers

Technisch-commercieel employés

Technisch-bedrijfskundıg medewerkers

Juridisch en fiscaal medewerkers

Juridisch, bestuurlijk medewerkers

Juristen

Administratieve transportemployes

Leidinggevenden

Managers

Medisch secretaresses

Programmeurs

Systeemanalisten

informatici

Technisch systeemanalisten

Activiteitenbegeleiders en medewerkers arbeidsbemiddeling

Medewerkers sociaal-cultureel werk en personeel en arbeid

Hoofden sociaal-cultureel werk en personeel en arbeid

Sociaal-wetenschappelijk medewerkers

Soclaal-wetenschappelijk onderzoekers

Interieurverzorgers

Verkopers

Winkeliers

Hulpkrachten horeca en verzorging

Ziekenverzorgenden

Verzorgend personeel

Café- en snackbarhouders

Bedrijfshoofden horeca

Bakkers en slagers

Aspirant politieagenten, soldaten en beveiligingshulpkrachten gemiddeld

gemiddeld

laag

gemiddeld

gemiddeld

laag

hoog

laag

gemiddeld

gemiddeld

gemiddeld

gemiddeld

gemiddeld

laag

gemiddeld

erg laag

gemiddeld

hoog

laag

hoog

erg hoog

gemiddeld

erg hoog

gemiddeld

hoog

gemiddeld

erg hoog

laag

hoog

gemiddeld

gemiddeld

gemiddeld

gemiddeld

gemiddeld

gemiddeld

gemiddeld

gemiddeld

gemiddeld

gemiddeld

noog

erg laag

erg laag

gemiddeld

gemiddeld

gemiddeld

noog

gemiddeld

gemiddeld

erg hoog

gemiddeld

gemiddeld

hoog

gemiddeld

gemiddeld

gemiddeld

erg laag

gemiddeld 
Tabel 4.4 (vervolg)

Venwachte baanopeningen per beroepsgroep. Limburg, 1999-2004 (percentage van de werkgelegenheid)

Beroepsgroep $\quad \% \quad$ typering

Politieagenten, onderofficieren en beveiligingsemployes

18

gemiddeld

Politie-inspecteurs en officieren

laag

Brandweerlieden

gemiddeld

Totaal

27

Bron: ROA 
Tabel 4.5

Verwachte uitbreidingsvraag per opleidingstype, Limburg, 1999-2004 (percentage van de werkgelegenheid)

Opleidingstype $\quad \% \quad$ typering

Basisonderwijs

\section{VMBO theorie}

VMBO landbouw en natuurlijke omgeving

VMBO bouwtechniek

VMBO installatietechniek

VMBO metaal: mechanische techniek $\quad-30$

VMBO voertuigentechniek $\quad-27$

VMBO elektrotechniek

VMBO grafische techniek

VMBO brood en banket

VMBO consumptief en levensmiddelentechniek

VMBO transport en logistiek

VMBO administratie, handel en mode

VMBO (uiterlijke) verzorging

VMBO beveiliging

HAVONWO

$M B O$ landbouw en veeteelt

MBO milieu en groene ruimte

MBO laboratorium

MBO bouw

MBO grond-, weg- en waterbouw

MBO installatietechniek

MBO werktuigbouw en mechanische techniek

MBO fijnmechanische techniek

MBO motorvoertuigentechniek

$M B O$ vliegtuigtechniek

MBO operationele techniek

MBO elektrotechniek

MBO grafische techniek

MBO procestechniek

MBO brood en banket

MBO levensmiddelentechniek/vleesverwerking

MBO vervoer en logistiek

MBO dokters-, tandarts- en dierenartsassistent

MBO apothekersassistent

MBO verpleging

MBO gezondheidstechniek

MBO sociaal-cultureel

-

$M B O$ verzorging

MBO uiterlijke verzorging

MBO horeca

MBO beweging en therapie

$M B O$ administratie

MBO handel

MBO secretariaat

MBO toerisme en recreatie

MBO openbare orde en veiligheid

$\mathrm{HBO}$ lerarenopleiding basisonderwijs

HBO lerarenopleiding talen

HBO lerarenopleiding natuur en techniek

erg laag

gemiddeld

erg laag

erg laag

erg laag

erg laag

erg laag

erg laag

erg laag

erg laag

laag

erg laag

laag.

gemiddeld

hoog

gemiddeld

gemiddeld

hoog

erg laag

laag

laag

laag

laag

laag

laag

erg laag

gemiddeld

laag

erg laag

gemiddeld

erg laag

laag

gemiddeld

gemiddeld

hoog

gemiddeld

hoog

gemiddeld

laag

gemiddeld

gemiddeld

gemiddeld

gemiddeld

gemiddeld

gemiddeld

hoog

laag

gemiddeld

erg laag

laag

HBO lerarenopleiding economie en maatschappij

gemiddeld

laag

laag

$H B O$ lerarenopleiding medisch en verzorging

HBO lerarenopleiding expressie

laag

$\mathrm{HBO}$ tolk en vertaler

HBO landbouw en veeteelt

HBO milieukunde en levensmiddelentechnologie

gemiddeld

erg hoog

HBO laboratorium

HBO bouwkunde

HBO civiele techniek

HBO werktuigbouwkunde

gemiddeld

laag

gemiddeld

laag

gemiddeld 


Opleidingstype $\quad \% \quad$ typering

\author{
HBO elektrotechniek \\ HBO informatica \\ HBO chemische technologie \\ HBO vervoer en logistiek \\ $\mathrm{HBO}$ verpleegkunde \\ $\mathrm{HBO}$ (fysio)therapie \\ $\mathrm{HBO}$ voeding \\ HBO accountancy en bedrijfseconomie \\ HBO commerciele economie \\ $\mathrm{HBO}$ toerisme en recreatie \\ $H B O$ recht en bestuur \\ $\mathrm{HBO}$ secretariaat \\ HBO bedrijfskunde \\ $\mathrm{HBO}$ communicatie en journalistiek \\ $H B O$ maatschappelijk werk en hulpverlening \\ HBO personeel en arbeid \\ HBO bibliotheek en documentatie \\ HBO uitvoerende en beeldende kunsten \\ HBO openbare orde en veiligheid \\ WO letteren \\ Wo theologie \\ WO landbouw en milieukunde \\ WO wiskunde en natuunwetenschappen \\ Wo bouwkunde \\ WO civiele techniek \\ WO werktuigbouwkunde \\ WO elektrotechniek \\ WO informatica en bestuurlijke informatiekunde \\ WO (dier)geneeskunde \\ WO tandheelkunde \\ Wo farmacie \\ WO econom(etr)ie \\ wO bedrijfskunde \\ WO accountancy en belastingen \\ WO rechten en bestuurskunde \\ WO sociale wetenschappen \\ WO kunstwetenschappen
}

gemiddeld

erg hoog

gemiddeld

gemiddeld

gemiddeld

gemiddeld

hoog

gemiddeld

hoog

hoog

hoog

gemiddeld

hoog

erg hoog

gemiddeld

gemiddeld

hoog

gemiddeld

gemiddeld

gemiddeld

laag

gemiddeld

laag

erg laag

laag

laag

gemiddeld

erg hoog

laag

gemiddeld

gemiddeld

erg hoog

erg hoog

hoog

gemiddeld

gemiddeld

gemiddeld

Totaal.

Bron: ROA 
Verwachte (netto) vervangingsvraag per opleidingstype, Limburg, 1999-2004 (percentage van de werkgelegenheid)

$\%$

Basisonderwijs

VMBO theorie

VMBO landbouw en natuurlijke omgeving

VMBO bouwtechniek

VMBO installatietechniek

VMBO metaal: mechanische techniek

VMBO voertuigentechniek

VMBO elektrotechniek

VMBO grafische techniek

VMBO brood en banket

VMBO consumptief en levensmiddelentechniek

VMBO transport en logistiek

VMBO administratie, handel en mode

VMBO (uiterlijke) verzorging

VMBO beveiliging

HAVOMNO

MBO landbouw en veeteelt

MBO milieu en groene ruimte

MBO laboratorium

MBO bouw

MBO grond-. weg- en waterbouw

$M B O$ installatietechniek

MBO werktuigbouw en mechanische techniek

MBO fijnmechanische techniek

MBO motorvoertuigentechniek

MBO vliegtuigtechniek

MBO operationele techniek

MBO elektrotechniek

MBO grafische techniek

MBO procestechniek

MBO brood en banket

MBO levensmiddelentechniek/vleesverwerking

$M B O$ vervoer en logistiek

MBO dokters-, tandarts- en cierenartsassistent

MBO apothekersassistent

MBO verpleging

MBO gezondheidstechniek

MBO sociaal-cultureel

$M B O$ verzorging

MBO unterlijke verzorging

MBO horeca

MBO beweging en therapie

$M B O$ admınistratie

MBO handel

MBO secretanaat

MBO toerisme en recreatie

MBO openbare orde en veligheid

HBO lerarenopleiding basısonderwijs

HBO lerarenopleiding talen

HBO lerarenopleiding natuur en techniek

HBO lerarenopleiding economie en maatschappij

$\mathrm{HBO}$ lerarenopleiding lichamelijke opvoeding

HBO lerarenopleiding medisch en verzorging

$H B O$ lerarenopleiding expressie

$\mathrm{HBO}$ tolk en vertaler

$H B O$ landbouw en veeteelt

HBO milieukunde en levensmiddelentechnologie

HBO laboratorium

HBO bouwkunde

HBO civiele techniek typering

gemiddeld

hoog

gemiddeld

gemiddeld

erg hoog

hoog

laag

erg hoog

erg hoog

hoog

hoog

gemiddeld

hoog

erg hoog

gemiddeld

erg hoog

gemiddeld

laag

gemiddeld

laag

hoog

laag

hoog

gemiddeld

laag

gemıddeld

laag

gemiddeld

hoog

erg laag

gemiddeld

gemiddeld

gemiddeld

laag

erg hoog

gemiddeld

laag

gemiddeld

hoog

gemiddeld

laag

gemiddeld

gemiddeld

gemiddeld

gemiddeld

erg laag

laag

hoog

erg hoog

gemiddeld

hoog

hoog

hoog

erg hoog

erg laag

laag

laag

noog

gemiddeld

gemiddeld 
Verwachte (netto) vervangingsvraag per opleidingstype, Limburg, 1999-2004 (percentage van de werkgelegenherd)

$\%$

HBO werktuigbouwkunde

$\mathrm{HBO}$ elektrotechniek

HBO informatica

HBO chemische technologie

$H B O$ vervoer en logistiek

$H B O$ verpleegkunde

$\mathrm{HBO}$ (fysio)therapie

$H B O$ voeding

$H B O$ accountancy en bedrijiseconomie

HBO commerciéle economie

HBO toerisme en recreatie

HBO recht en bestuur

$\mathrm{HBO}$ secretariaat

HBO bedrijfskunde

HBO communicatie en journalistiek

HBO maatschappelijk werk en hulpverlening

HBO personeel en arbeid

$\mathrm{HBO}$ bibliotheek en documentatie

HBO uitvoerende en beeldende kunsten

$\mathrm{HBO}$ openbare orde en veiligheid

WO letteren

WO theologie

WO landbouw en milieukunde

WO wiskunde en natuurwetenschappen

WO bouwkunde

WO civiele techniek

WO werktuigbouwkunde

WO elektrotechniek

WO informatica en bestuurlijke informatiekunde

WO (dier)geneeskunde

WO tandheelkunde

Wo farmacie

WO econom(etr)ie

WO bedrijfskunde

WO accountancy en belastingen

WO rechten en bestuurskunde

WO sociale wetenschappen

WO kunstwetenschappen typerng

hoog

gemiddeld

gemiddeld

erg hoog

gemıddeld

gemiddeld

laag

gemiddeld

gemiddeld

laag

laag

laag

erg hoog

erg laag

erg laag

gemiddeld

gemiddeld

hoog

gemiddeld

hoog

laag

hoog

erg laag

gemiddeld

gemiddeld

hoog

erg laag

laag

erg laag

gemiddeld

gemiddeld

erg laag

laag

erg laag

gemiddeld

gemiddeld

gemidldeld

erg laag

Totaal

Bron: ROA 
Tabel 4.7

Verwachte baanopeningen per opleidingstype, Limburg, 1999-2004 (percentage van de werkgelegentheid)

Opleidingstype

$\%$

typering

Basisonderwijs

VMBO theorie

VMBO landbouw en natuurlijke amgeving

VMBO bouwtechniek

VMBO installatietechniek

VMBO metaal: mechanische techniek

VMBO voertuigentechniek

VMBO elektrotechniek

VMBO grafische techniek

VMBO brood en banket

VMBO consumptief en levensmiddelentechniek

VMBO transport en logistiek

VMBO administratie, handel en mode

VMBO (uiterlijke) verzarging

VMBO beveiliging

HAVOMNO

MBO landbouw en veeteelt

22

36

18

22

$-$

27

14

31

-

$-$

20

27

37

47

MBO milieu en groene ruimte

$M B O$ laboratorium

MBO bouw

MBO grond-, weg- en waterbouw

$M B O$ installatietechniek

MBO werktuigbouw en mechanische techniek

MBO fijnmechanische techniek

MBO motorvoertuigentechniek

MBO vliegtuigtechniek

MBO operationele techniek

MBO elektrotechniek

MBO grafische techniek

MBO procestechniek

MBO brood en banket

MBO levensmiddelentechniek/vleesverwerking

$M B O$ vervoer en logistiek

MBO dokters-, tandarts- en dierenartsassistent

MBO apothekersassistent

$M B O$ verpleging

MBO gezondheidstechniek

MBO sociaal-cultureel

$M B O$ verzorging

$M B O$ uiterlijke verzorging

MBO horeca

MBO beweging en therapie

$M B O$ administratie

MBO handel

MBO secretariaat

MBO toerisme en recreatie

MBO openbare orde en veiligheid

HBO lerarenopleiding basisonderwijs

$H B O$ lerarenopleiding talen

HBO lerarenopleiding natuur en techniek

HBO lerarenopleiding economie en maatschappij

HBO lerarenopleiding lichamelijke opvoeding

$\mathrm{HBO}$ lerarenopleiding medisch en verzorging

$\mathrm{HBO}$ lerarenopleiding expressie

HBO tolk en vertaler

$H B O$ landbouw en veeteelt

HBO milieukunde en levensmiddelentechnologie

HBO laboratorium

HBO bouwkunde

HBO civiele techniek

$\mathrm{HBO}$ werktuigbouwkunde laag

hoog

laag

laag

hoog

gemidideld

erg laag

gemiddeld

gemiddeld

gemiddeld

gemiddeld

laag

gemiddeld

hoog

hoog

eig hoog

gemiddeld

hoog

laag

erg laag

gemiddeld

erg laag

gemiddeld

laag

erg laag

laag

laag

erg laag

gemiddeld

erg laag

laag

laag

gemiddeld

gemiddeld

erg hoog

laag

gemiddeld

hoog

gemiddeld

hoog

gemiddeld

gemiddeld

gemiddeld

gemiddeld

hoog

hoog

erg laag

gemiddeld

gemiddeld

laag

hoog

gemiddeld

gemiddeld

gemiddeld

gemiddeld

erg hoog

gemiddeld

gemiddeld

laag

laag

gemiddeld 


\section{$\mathrm{HBO}$ elektrotechniek}

$\mathrm{HBO}$ informatica

HBO chemische technologie

HBO vervoer en logıstiek

$\mathrm{HBO}$ verpleegkunde

$\mathrm{HBO}$ (fysio)therapie

$H B O$ voeding

$H B O$ accountancy en bedrifseconomie

HBO commercièle economie

HBO toerisme en recreatie

$\mathrm{HBO}$ recht en bestuur

$\mathrm{HBO}$ secretariaat

HBO bedrijtskunde

HBO communicatie en journalistiek

HBO maatschappelijk werk en hulpverlening

HBO personeel en arbeid

HBO bibilotheek en documentatie

$H B O$ uitvoerende en beeldende kunsten

$\mathrm{HBO}$ openbare orde en veiligheid

WO letteren

WO theologie

WO landbouw en milieukunde

WO wiskunde en natuurwetenschappen

WO bouwkunde

WO civiele techniek

WO werktuigbouwkunde

WO elektrotechniek

WO informatica en bestuurlijke informatiekunde

WO (dier)geneeskunde

WO tandheelkunde

WO farmacie

WO econom(etr)ie

WO bedrijfskunde

WO accountancy en bellastingen

WO rechten en bestuurskunde

WO sociale wetenschappen

WO kunstwetenschappen gemiddeld

erg hoog

hoog

gemiddeld

hoog

gemiddeld

hoog

hoog

hoog

hoog

hoog

erg hoog

hoog

erg hoog

gemiddeld

gemiddeld

erg hoog

gemiddeld

gemiddeld

gemiddeld

gemiddeld

laag

laag

laag

laag

erg laag

gemiddeld

erg hoog

laag

gemiddeld

erg laag

erg hoog

erg hoog

erg hoog

laag

gemiddeld

erg laag

Totaa!

29

Bron: ROA 


\section{Tabel 4.8}

Verwachte arbeidsmarktinstroom van schoolverlaters per opleidingstype, Limburg. 1999-2004 (percentage van de werkgelegenheid)

Opleidingstype

Basisonderwijs

VMBO theorie

VMBO landbouw en natuurlijke omgeving

VMBO bouwtechniek

VMBO installatietechniek

VMBO metaal: mechanische techniek

VMBO voertuigentechniek

VMBO elektrotechniek

VMBO grafische techniek

VMBO brood en banket

VMBO consumptief en levensmiddelentechniek

VMBO transport en logistiek

VMBO administratie, handel en mode

VMBO (uiterlijke) verzorging

VMBO beveiliging

HAVONWO

$M B O$ landbouw en veeteelt

MBO milieu en groene ruimte

MBO laboratorium

MBO bouw

MBO grond-, weg- en waterbouw

MBO installatietechniek

MBO werktuigbouw en mechanische techniek

MBO fijnmechanische techniek

MBO motorvaertuigentechniek

MBO vliegtuigtechniek

MBO operationele techniek

MBO elektrotechniek

MBO grafische techniek

MBO procestechniek

MBO brood en banket

MBO levensmiddelentechniek/vleesverwerking

$M B O$ vervoer en logistiek

MBO dokters-, tandarts- en dierenartsassistent

MBO apothekersassistent

$M B O$ verpleging

MBO gezondheidstechniek

MBO sociaal-cultureel

$M B O$ verzorging

$M B O$ uiterilike verzorging

MBO horeca

MBO beweging en therapie

MBO administratie

MBO handel

MBO secretariaat

$M B O$ toerisme en recreatie

MBO openbare orde en veiligheid
$\% \quad$ typering

gemiddeld

gemiddeld

gemiddeld

gemiddeld

erg hoog

laag

gemiddeld

gemiddeld

gemiddeld

hoog

hoog

laag

hoog

gemiddeld

erg hoog

hoog

laag

hoog

gemiddeld

gemiddeld

gemiddeld

gemiddeld

gemiddeld

laag

laag

erg laag

hoog

gemiddeld

gemiddeld

laag

gemiddeld

laag

laag

erg hoog

erg hoog

laag

laag

erg hoog

gemiddeld

gemiddeld

hoog

hoog

gemiddeld

gemiddeld

gemiddeld

hoog

laag

Totaal

Bron: ROA 
Tabel 4.9

Indicator Toekomstige Arbetdsmarktperspectieven (ITA) en Indicator Toekomstige Knelpunten in de Personeelsvoorziening (ITK.P) naar opleiding. Limburg. 1999-2004

\begin{tabular}{|c|c|c|c|c|}
\hline Opleidingstype & ITA & typering & ITKP & typerng \\
\hline Basisonderwijs & 1,02 & redelijk & 1.23 & geen \\
\hline VMBO theorie & 0.94 & goed & 0.94 & groot \\
\hline VMBO landbouw en natuurijke omgeving & 1,07 & matig & 1,37 & geen \\
\hline VMBO bouwtechniek & 1,07 & matig & 1,29 & geen \\
\hline VMBO installatietechniek & - & redelijk & - & geen \\
\hline VMBO metaat: mechanische techniek & 0.87 & goed & 1.14 & vrijwel geen \\
\hline VMBO voertuigentechniek & 1,04 & redelijk & 1.36 & geen \\
\hline VMBO elektrotechniek & 0,90 & goed & 1.02 & enige \\
\hline VMBO grafische techniek & - & goed & - & geen \\
\hline VMBO brood en banket & - & goed & - & geen \\
\hline VMBO conisumptief en levensmiddelentechniek & - & matig & - & geen \\
\hline VMBO transport en logistiek & 0,96 & goed & 1.15 & vrijwel geen \\
\hline VMBO administratie, handel en mode & 1,11 & matig & 1.15 & geen \\
\hline VMBO (uiterlijke) verzorging & 0.89 & goed & 0.89 & groot \\
\hline VMBO beveiliging & - & matig & - & vrijwel geen \\
\hline HAVONWO & 0.96 & goed & 0,96 & groot \\
\hline MBO landbouw en veeteelt & 0.84 & zeer goed & 0.84 & zeer groot \\
\hline MBO milleu en groene ruimte & - & goed & - & groot \\
\hline MBO laboratorium & - & matig & - & geen \\
\hline MBO bouw & 1,04 & redelijk & 1.06 & vrijwel geen \\
\hline MBO grond-, weg- en waterbouw & - & redelijk & - & vrijwel geen \\
\hline MBO installatietechniek & 1,11 & matig & 1.20 & geen \\
\hline MBO werktuigbouw en mechanische techniek & 1,00 & redelijk & 1,14 & vrijwel geen \\
\hline MBO fijnmechanische techniek & - & goed & - & vrijwel geen \\
\hline MBO motorvoertuigentechnek & 0,98 & goed & 1.03 & enige \\
\hline MBO vliegtuigtechniek & - & goed & - & vrijwel geen \\
\hline MBO operationele techniek & - & slecht & - & geen \\
\hline MBO elektrotechniek & 1.00 & goed & 1.05 & vrijwel geen \\
\hline MBO grafische techniek & 0.97 & goed & 1,19 & geen \\
\hline MBO procestechniek & 0.97 & goed & 0,97 & groot \\
\hline MBO brood en bankel & 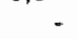 & goed & 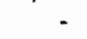 & geen \\
\hline MBO levensmiddelentechniek/vleesverwerking & - & goed & - & groot \\
\hline MBO vervoer en logistiek & 0,92 & goed & 0,92 & groot \\
\hline MBO dokters-, tandarts- en dierenartsassistent & - & matig & - & vrijwel geen \\
\hline MBO apothekersassistent & - & redelijk & . & enige \\
\hline MBO verpleging & 0,88 & goed & 0.88 & groot \\
\hline MBO gezondheidstechniek & - & zeer goed & - & zeer groot \\
\hline MBO sociaal-cultureel & 4,06 & matig & 1,06 & vrijwel geen \\
\hline MBO verzorging & 0,95 & goed & 0,95 & groot \\
\hline MBO uiterlijke verzorging & 0.91 & goed & 0,91 & groot \\
\hline MBO horeca & 1,00 & goed & 1,00 & grool \\
\hline MBO beweging en therapie & 1.13 & matıg & 1.13 & vrijwel geen \\
\hline MBO administratie & 1,00 & redelijk & 1.00 & enige \\
\hline MBO handel & 0.95 & goed & 0.95 & groot \\
\hline MBO secretariaat & 0.93 & goed & 0.93 & groot \\
\hline MBO toerisme en recreatie & - & redelijk & - & enige \\
\hline MBO openbare orde en veiligheid & 0.95 & goed & 0.97 & groot \\
\hline
\end{tabular}

Bron: ROA 


\begin{tabular}{|c|c|c|c|c|}
\hline Opleidingstype & $\begin{array}{l}\text { conjunctuur- } \\
\text { gevoeligheid }\end{array}$ & typering & $\begin{array}{r}\text { spreidings- } \\
\text { index }\end{array}$ & typering \\
\hline Basisonderwijs & 0.97 & gemiddeld & 20.56 & erg hoog \\
\hline VMBO theorie & 0.82 & gemiddeld & 19.08 & erg hoog \\
\hline VMBO landbouw en natuurlijke omgeving & 0.64 & gemiddeld & 6.18 & gemiddeld \\
\hline VMBO bouwtechniek & 1.54 & erg hoog & 4.82 & laag \\
\hline VMBO installatietechniek & 1.76 & erg hoog & 6.60 & gemiddeld \\
\hline VMBO mechanische techniek & 1.26 & noog & 10.66 & hoog \\
\hline VMBO fijnmechanische techniek & 1.23 & hoog & 15.24 & hoog \\
\hline VMBO motorvoertuigentechniek & 1.24 & noog & 9.53 & gemiddeld \\
\hline VMBO elektrotechniek & 1.19 & noog & 12.67 & hoog \\
\hline VMBO grafische techniek & 1,42 & erg hoog & 6.51 & gemiddeld \\
\hline VMBO brood en banket & 1.27 & hoog & 11.61 & hoog \\
\hline VMBO horeca en levensmiddelentechniek & 1.00 & gemiddeld & 11.48 & noog \\
\hline VMBO vervoer & 1.48 & erg hoog & 2.17 & erg hoog \\
\hline VMBO admınistratıe, handel en textiel & 0,73 & gemiddeld & 14,42 & hoog \\
\hline VMBO verzorging & 0,60 & laag & 11.03 & noog \\
\hline VMBO beveiliging & 0.64 & gemiddeld & 3.84 & laag \\
\hline HAVOMWO & 0.85 & gemiddeld & 16.78 & hoog \\
\hline MBO landbouw en veeteelt & 0,51 & laag & 4.61 & laag \\
\hline MBO milieu en groene ruimte & 0,45 & laag & 3.93 & laag \\
\hline MBO laboratorium & 0,51 & laag & 6.38 & gemiddeld \\
\hline MBO bouw & 1.57 & erg hoog & 3.78 & laag \\
\hline MBO grond-, weg- en waterbouw & 1.33 & erg hoog & 6.81 & gemiddeld \\
\hline MBO installatietechniek & 9,52 & erg hoog & 2.37 & erg laag \\
\hline MBO werktuigb. en mech. techn & 1,16 & hoog & 9.05 & gemiddeld \\
\hline MBO fijnmechanische techniek & 1.23 & hoog & 9.52 & gemiddeld \\
\hline MBO motorvoentuigentechniek & 1,10 & noog & 4.09 & laag \\
\hline MBO vliegtuigtechniek & 1,10 & hoog & 5.42 & laag \\
\hline MBO operationele techniek & 1.07 & hoog & 5.30 & laag \\
\hline MBO elektrotechniek & 1,13 & hoog & 7.07 & gemiddeld \\
\hline MBO grafische techniek & 1.27 & hoog & 5,21 & laag \\
\hline MBO procestechniek & 0.84 & gemiddeld & 3.71 & laag \\
\hline MBO brood en banket & 0.40 & laag & 6.01 & gemiddeld \\
\hline MBO levensmiddelentechnologie & 0,62 & laag & 7.23 & gemiddeld \\
\hline MBO vervoer & 1.30 & hoog & 11.03 & hoog \\
\hline MBO dokters-, tandarts- en dierenartsass & 0.59 & laag & 2.55 & erg laag \\
\hline MBO apothekersassistent & 0.43 & laag & 1.67 & erg laag \\
\hline MBO verpleging & 0.61 & laag & 3.17 & erg laag \\
\hline MBO ondheidstechnsek & 0.43 & laag & 1.83 & erg laag \\
\hline MBO sociaal-cultureel & 0.80 & gemiddeld & 9.58 & gemiddeld \\
\hline MBO verzorging & 0.70 & gemiddeld & 6.54 & gemiddeld \\
\hline MBO uiterlijke verzorging & 0.77 & gemiddeld & 3.41 & erg laag \\
\hline MBO horeca & 0.93 & gemiddeld & 7.95 & gemiddeld \\
\hline MBO beweging en therapie & 0.69 & gemiddeld & 9.34 & gemiddeld \\
\hline MBO administratte & 0.87 & gemiddeld & 6,06 & gemiddeld \\
\hline MBO handel & 0.83 & gemiddeld & 12.86 & erg hoog \\
\hline MBO secretarıat & 0.76 & gemiddeld & 3,75 & laag \\
\hline MBO toerisme en recreatie & 0.83 & gemiddeld & 4.82 & laag \\
\hline MBO bedrijskunde & 0.92 & gemiddeld & 21.32 & erg hoog \\
\hline MBO automatisering & 0,91 & gemiddeld & 7.53 & gemiddeld \\
\hline MBO geld, bank en belastingen & 0,74 & gemiddeld & 5,56 & gemiddeld \\
\hline MBO verzekeringswezen & 0,90 & gemiddeld & 2.71 & erg laag \\
\hline MBO openbare orde en veiligheid & 0,55 & laag & 6.52 & gemiddeld \\
\hline
\end{tabular}


Whelassificaties 


$\sqrt{2}$

(89)

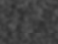

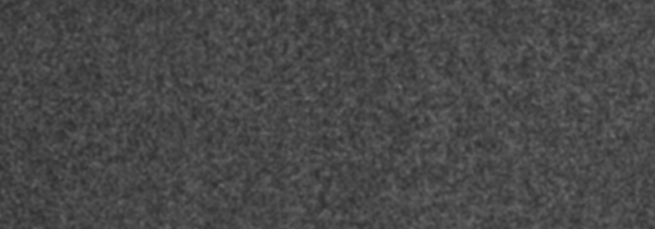

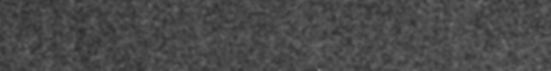

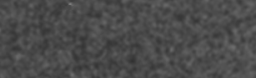

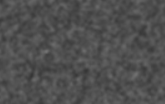

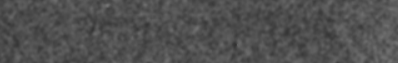

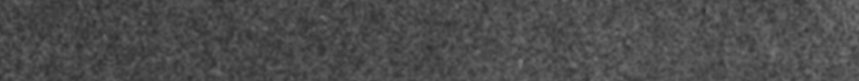
vichat

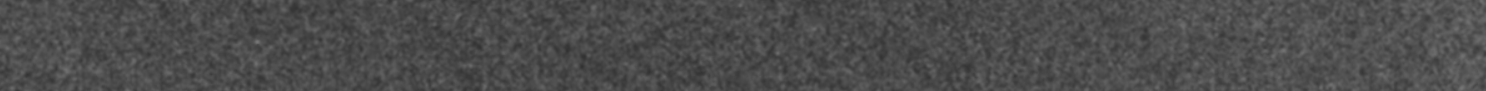
Q Q6. W.

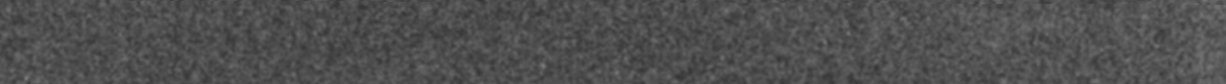

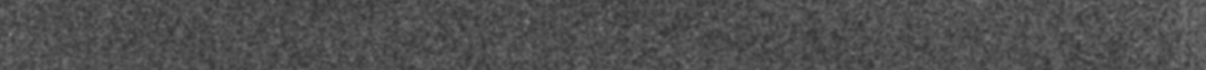

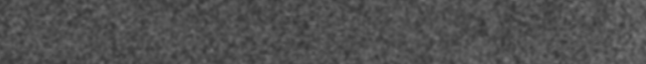
5.5.

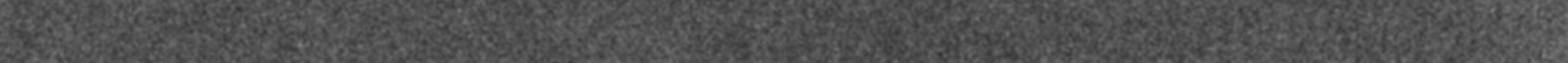

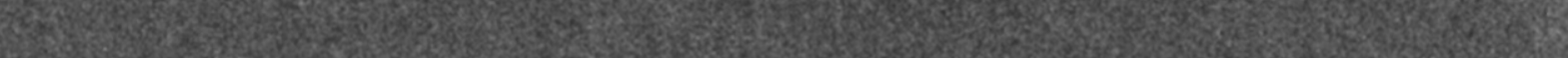

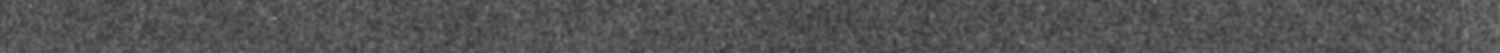

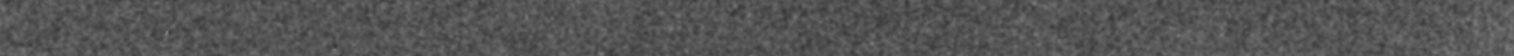

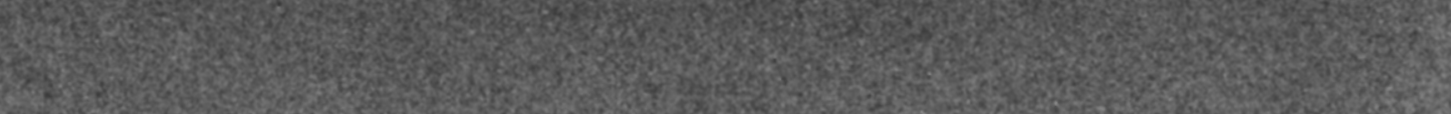
W.

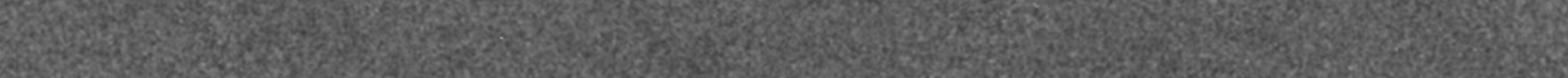
15. 


\author{
Opleidingsniveau \\ Opleidingscategorie \\ $\mathrm{Nr}$ Opleidingstype
}

sol

\section{Basisonderwijs}

001 Basisonderwijs

$00000-20199$

\section{VMBO, VMBO theorie}

VMBO theorie

002 VMBO theorie

VMBO Landbouw en natuurlike omgeving

003 VMBO landbouw en natuurlijke omgeving VMBO Techniek

004 VMBO bouwtechniek

005 VMBO installatietechniek

006 VMBO mechanische techniek

007 VMBO fijnmechanische techniek

008 VMBO motorvoertuigentechniek

009 VMBO elektrotechniek

$010 \quad$ VMBO grafische techniek

011 VMBO brood en banket

012 VMBO horeca en levensmiddelentechniek

013 VMBO vervoer

- VMBO techniek overig

VMBO Economie

015 VMBO administratie, handel en textiel

VMBO Verzorging

016 VMBO verzorging

VMBO Openbare orde en veiligheid

017 VMBO beveiliging

VMBO Overig

VMBO overig

\section{MBO, HAVOINWO}

\section{HAVOMWO}

019 HAVOMWO

MBO Landbouw en natuurlike omgeving

020 MBO landbouw en veeteell

021 MBO milieu en groene rumte

MBO Techniek

022 MBO laboratorium

023 MBO bouw

024 MBO grond- "weg-en waterbouw

$025 \mathrm{MBO}$ installatietechniek

026 MBO werktuigbouw \& mechanische techniek

027 MBO fijnmechanische techniek

028 MBO motorvortuigentechniek
$39100-39399$

$30690,31100-31199,31610$ $38430.38600-38699$.

39800-39999

$30100-30199$

$30637,32100-32999$

$33610-33615,33617-33629$

33616

$33631.33633,33638$

33635

33641

$33650-33659$

$33660-33669$

33676

$33677,34430,38140.38340$

34100-34399

$33100-33199,33642-33649$

$33670-33672,33674-33675$.

$33678-33684,33686-33699$

33673, $33685,36110-36699$

30667. 30671, 35100-35499, 37100-37199, 38100-38139, $38180-38199,38330$

$40100-40199$

$42110-42129.42150-42169$. $42188-42199.42220-42999$ $42130,42175,42183$

$43100-43199,45210-45219$ $43611-43615,43618-43619$, $43811-43815,43818-43819$ $43623-43625,43823-43825$ 43616,43816

$42210,43631,43633$,

$43638,43643,43647-43648$, $43833,43838,43843$, $43847-43848$,

$44231,44250-44299$

$43635,43835,45280$

$43641,43649,43841$ 


$\begin{array}{ll}029 & \text { MBO vliegtuigtechniek } \\ 030 & \text { MBO operationele techniek } \\ 031 & \text { MBO elektrotechniek } \\ 032 & \text { MBO grafische techniek } \\ 033 & \text { MBO procestechniek } \\ 034 & \text { MBO brood en banket } \\ 035 & \text { MBO levensmiddelentechniek/ } \\ & \text { vleesverwerking } \\ 036 & \text { MBO vervoer }\end{array}$

\section{MBO Economie}

MBO adminustratie

0.48

MBO handel

049

050

054

052

053

054

\section{MBO Openbare orde en veiligheid}

MBO secretariaat

MBO toerisme en recreatie

MBO bedriffskunde

MBO automatisering

MBO geld, bank en belastingen

MBO verzekeringswezen

MBO openbare orde en veiligheid

MBO Oveng

MBO overig

\section{HBO}

\section{HBO Onderwijs en tolk en vertaler}

057 $\mathrm{HBO}$ lerarenopleiding basisonderwijs

HBO lerarenopleiding talen

059

HBO lerarenopleiding natuur en techniek

060

HBO lerarenopleiding economie en maatschappiij

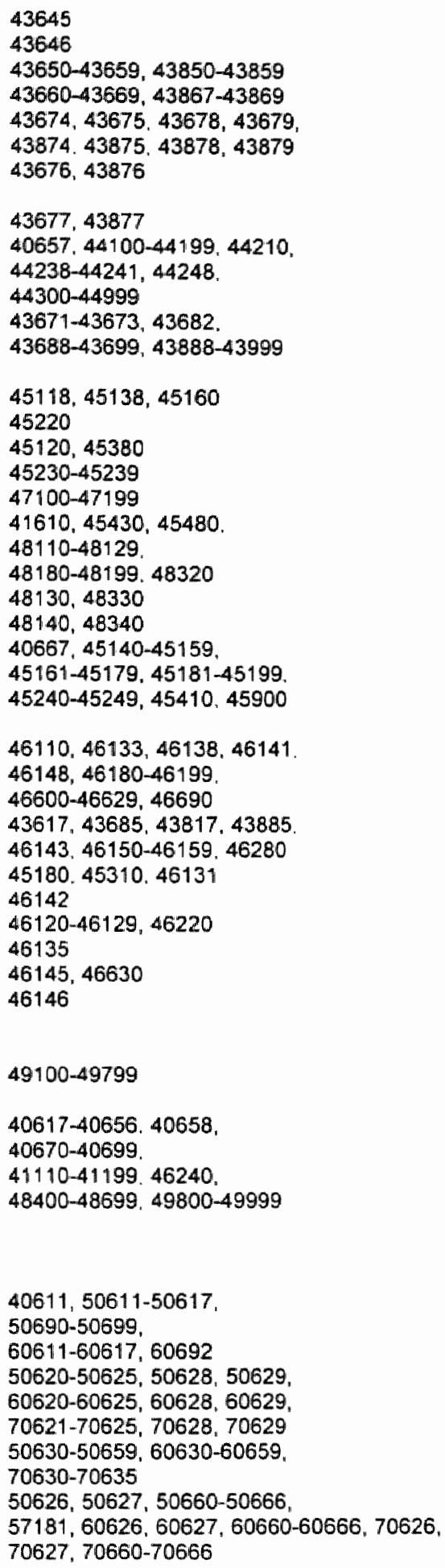

$40611,50611-50617$. 50690-50699, $60611-60617,60692$ $50620-50625,50628,50629$, $60620-60625,60628,60629$, $70621-70625,70628,70629$ 50630-50659, 60630-60659, 70630-70635

50626, 50627, 50660-50666, $57181,60626,60627,60660-60666,70626$, $70627,70660-70666$ 
$061 \mathrm{HBO}$ lerarenopleiding lichamelijke opvoeding

$062 \mathrm{HBO}$ lerarenopleiding medisch en verzorging

$063 \mathrm{HBO}$ lerarenopleiding expressie

$064 \mathrm{HBO}$ tolk en vertaler

\section{HBO Landbouw}

$065 \mathrm{HBO}$ landbouw en veeteelt

066 HBO milieukunde en levensmiddelentechnologie

HBO Techniek

067 HBO laboratorium

068 HBO bouwkunde

069 HBO civiele techniek

070 HBO werktuigbouwkunde

071 HBO elektrotechniek

$072 \mathrm{HBO}$ informatica

073 HBO chemische technologie

$074 \mathrm{HBO}$ vervoer en logistiek

HBO Paramedisch

$075 \mathrm{HBO}$ verpleegkunde

$076 \mathrm{HBO}$ (fysio) therapie

$077 \quad \mathrm{HBO}$ voeding

078 HBO radiologie

- HBO paramedisch overig

HBO Economie

080 HBO accountancy en bedrijfseconomie

081 HBO commercièle economie

$082 \mathrm{HBO}$ toerisme en recreatie

$083 \mathrm{HBO}$ recht en bestuur

$084 \mathrm{HBO}$ secretariaat

$085 \mathrm{HBO}$ bedrıfskunde

086

HBO Sociaal-cultureel

HBO communicatie en journalistiek

HBO maatschappelijk werk en hulpverlenıng

$\mathrm{HBO}$ personeelswerk

$\mathrm{HBO}$ bibliotheek en documentatie

$\mathrm{HBO}$ sociaal-cuitureel overig

HBO Kunst

091 HBO uitvoerende en beeldende kunsten

HBO Openbare orde en veiligherd

092 HBO openbare orde en veiligherd

HBO Oveng

HBO overig

wo

WO Letteren en theologie

094

WO letteren

095 WO theologie

WO Landbouw en milieukunde

096

WO landbouw en milieukunde
50667,60667

$50670-50679,60670-60679$

50680-50689,60680-60689,70680-70689

51100-51199

52110,52158

$52128-52130,52171-52299,52900,53677$ 53678

$53140,53149,53160,55210,55220$

$53610-53619.53810-53819$

$53620-53629,53820-53829$

$53631-53649,53830-53849$

$53110-53139,53150,53170-53190,53650$

$53651.53653-53655,53682,53683$

53652.56135

$53670-53676$

54100-54999

55120,55380

$55140-55149,55151,55153,55180.55238$

55420,58180

$55241-55243$

$55110-55119,55130-55133,55160,55190-$

$55199,55231,55248,55280,55480$

$56110,56133,56138,56210,56240,56249$. 56630

$56143-56180$

56142

$56611-56629,56690$

55310,56131

$52310,52350.52380,56120,56220$

56141.57120

51610. $57111,57115-57119.57188-57199$

57113

57130

$57141,57143,57145-57165$

$58610-58640,58680-58699,68610$

$59100-59499$

$53685-53699,53868,53885$

$53900,56190-56199$.

$58110-58125,58190,58340,58900-58999$. 59900-59999

$61100-61199,71100-71199$

61610,71610

$62110-62130,62158,62170-62180,62182-$ $62189,62200-62999,72175$ 
WO Techniek

097 WO wiskunde en natuurwetenschappen

098 WO bouwkunde

099 WO civiele techniek

100 WO werktuigbouwkunde

101 WO elektrotechniek

102 WO informatica en bestuurlitke informatiekunde WO Medisch

103 WO (dier)geneeskunde

104 WO tandheelkunde

105 WO farmacie

WO Economie

106 WO econom(etr)ie

107 WO bedrijfskunde

108 WO accountancy en belastingen

109 WO rechten en bestuurskunde

WO Sociaal-cultureel

110 WO sociale wetenschappen

WO sociaal-cultureel overig Wo Kunst

112 WO kunstwetenschappen

WO Overig

Wo overig
$63110-63199,63631,63670-63688,73110$ $73199.73674,73675$

$63613-63618,63818,73618$

$63623-63625,73623$

62181. 63643-63649.

$73645-73648$

$63650-63651,63653-63659,72181,73650-$

$73651,73653-73659$

$63652,66135,73652,76135$

$65111,65160.75111,75160$

65131,75131

$65200-65299,75200-75299$

$66110,66141-66219,66221-66240,76110$, $76141-76219$

$66120,66220,76120$

$66133,66630,76133,76630$

$66118,66610-66629$,

$66631-66699,76118,76610-76629$

$65148,65180-65199,67120,67130,67141-$ $67188,68110,68180,75148,75151,75180$, $77130,77141-77188$

$67110-67119,67190,77113$

68640

$63690,63900,65380,65480,65900,68690$, 69150-69999 


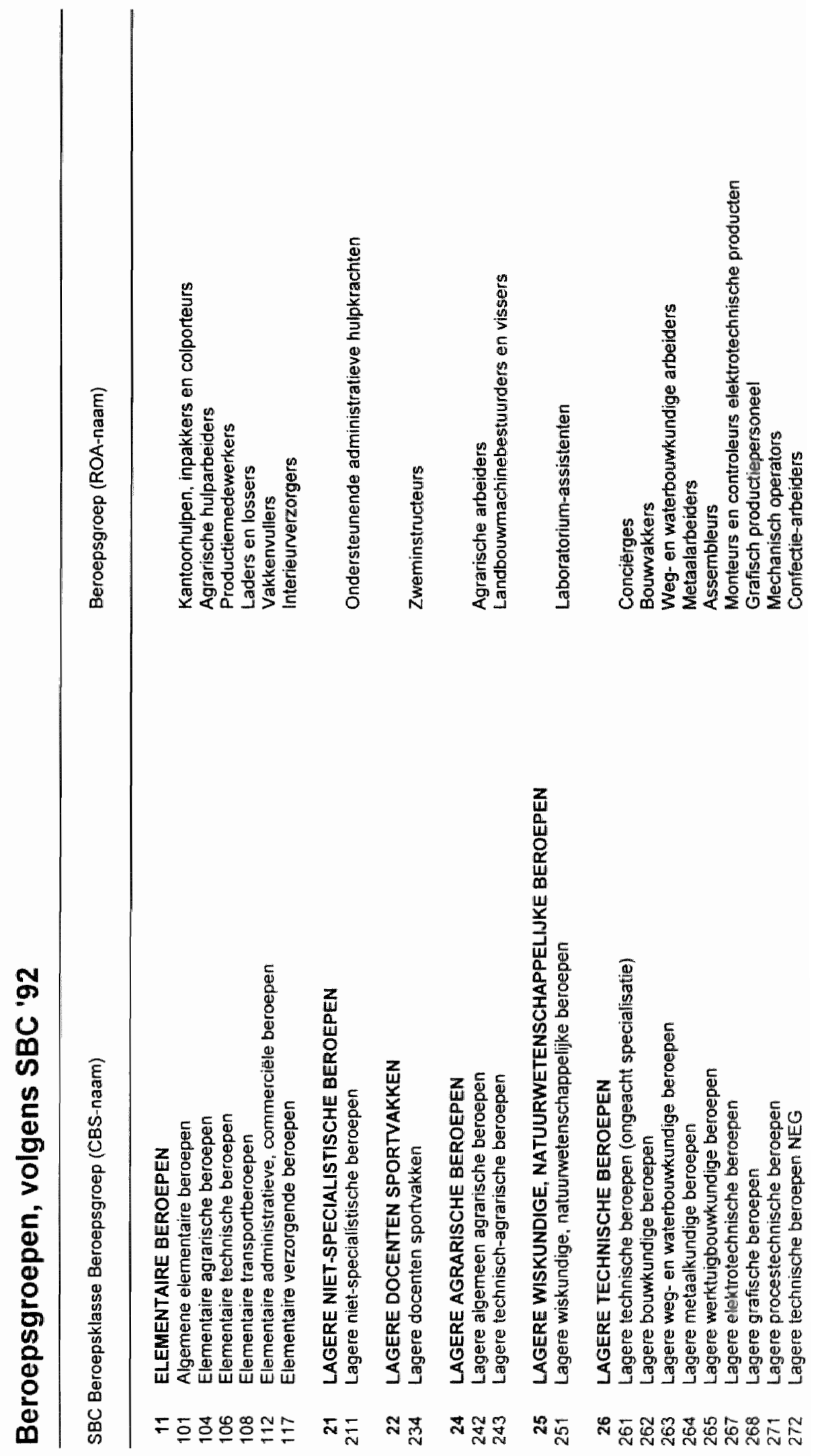




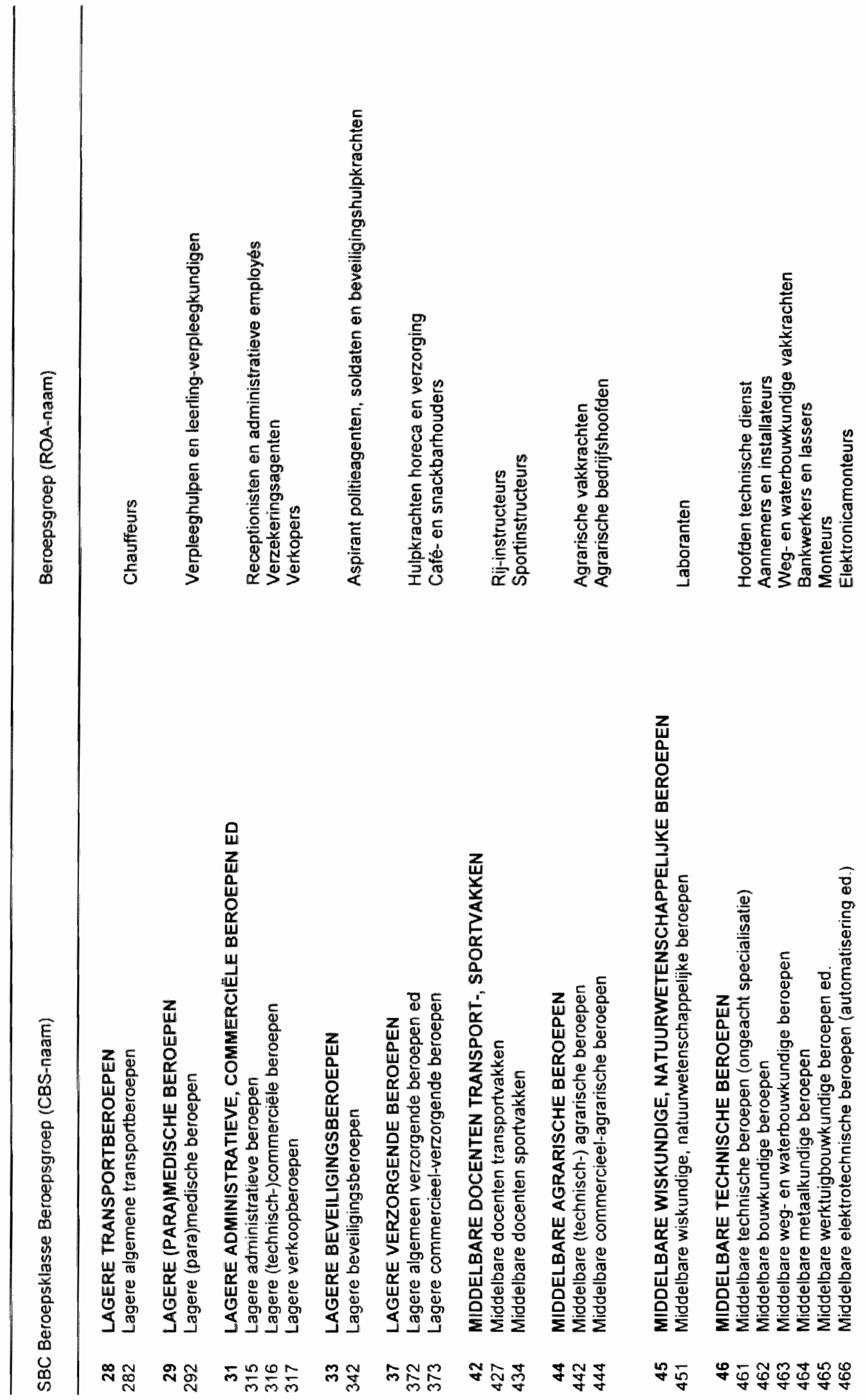




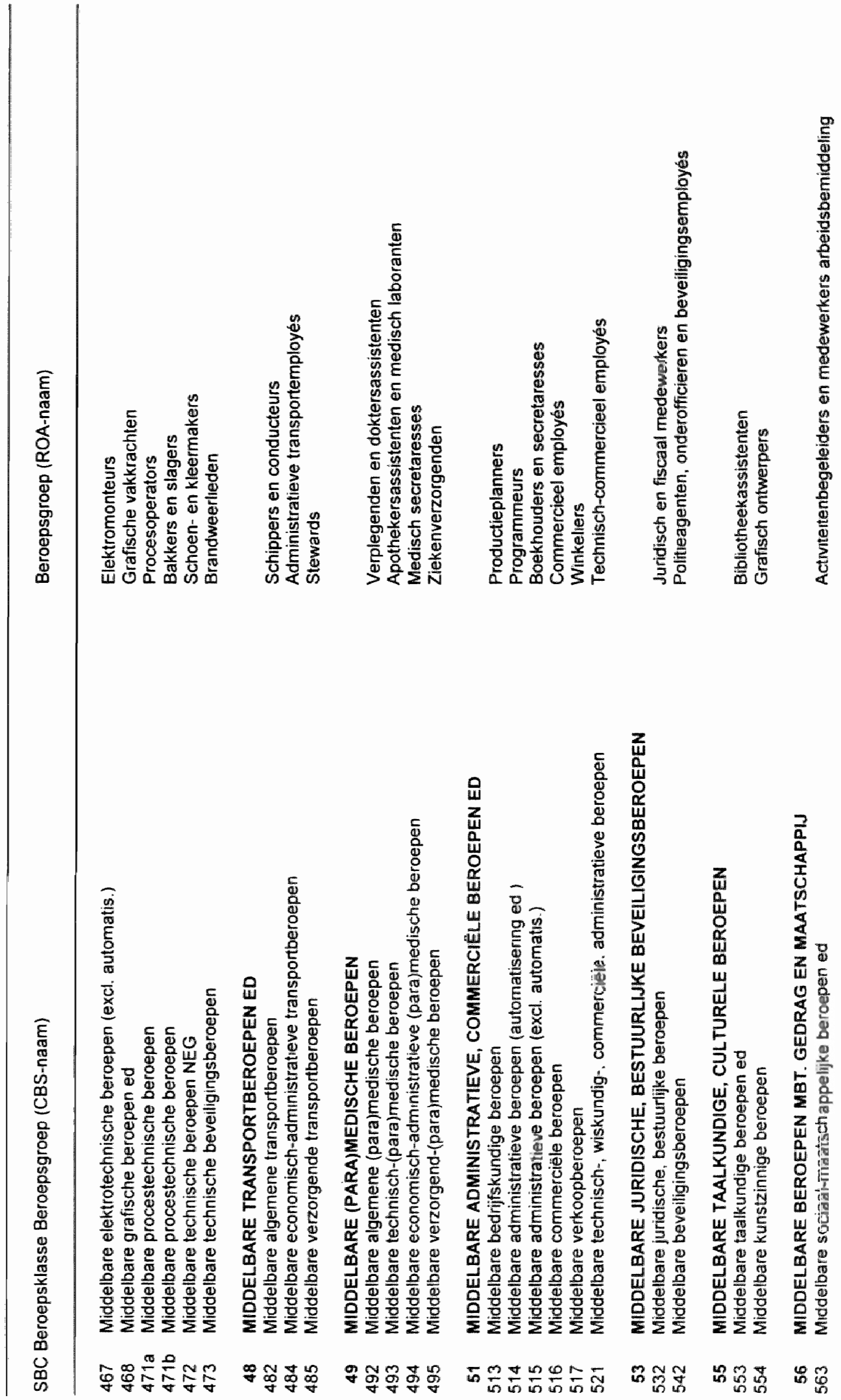




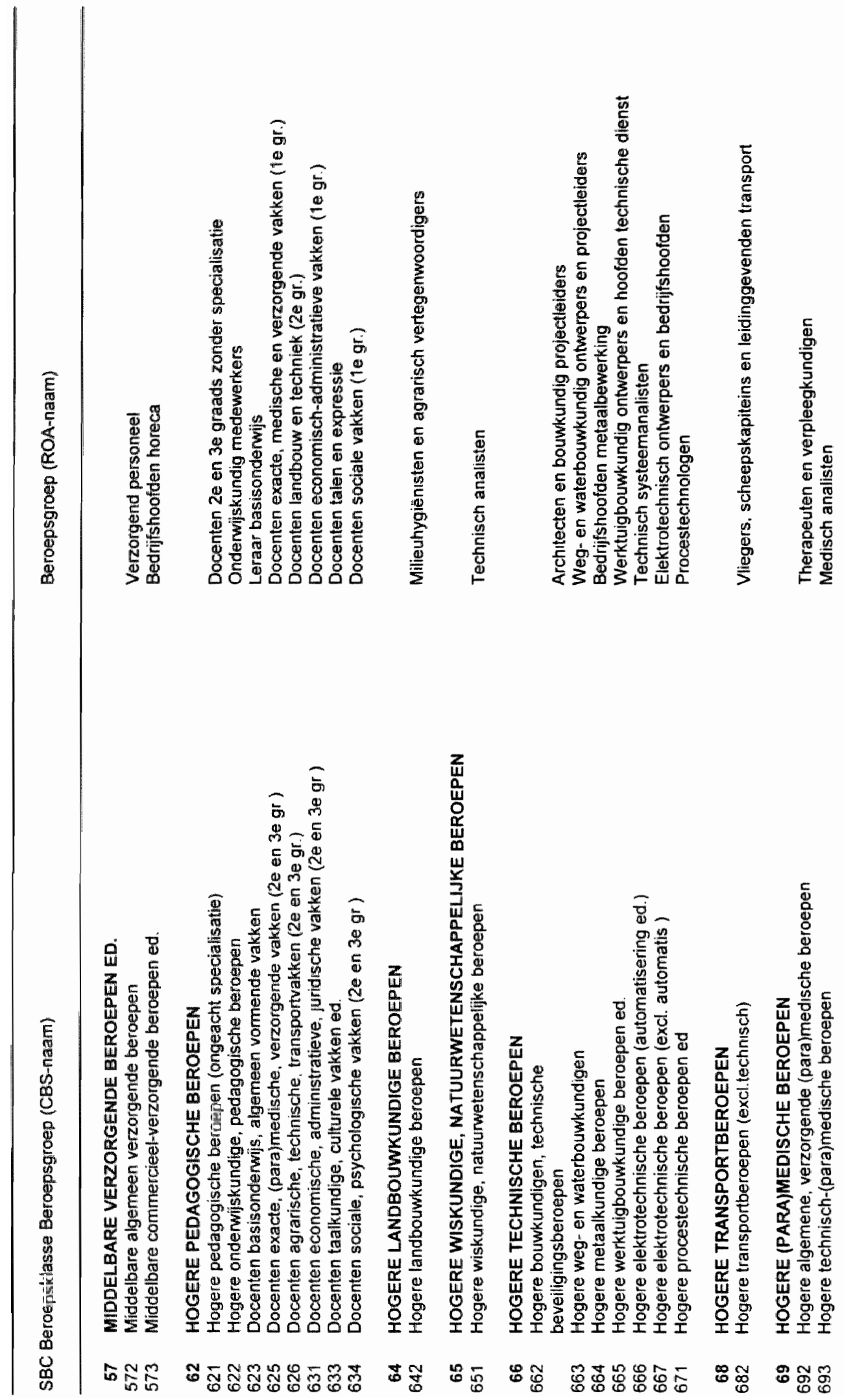




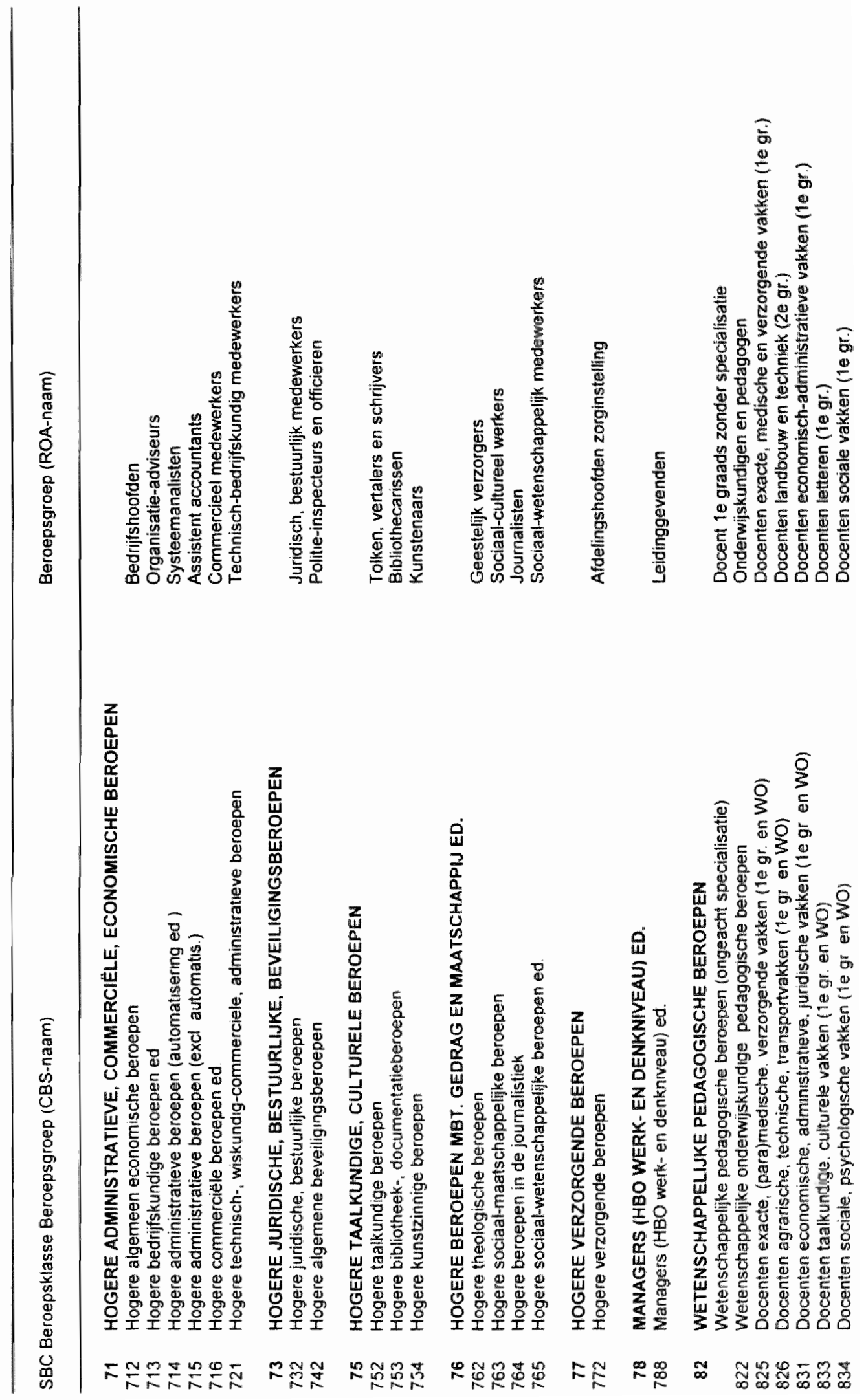




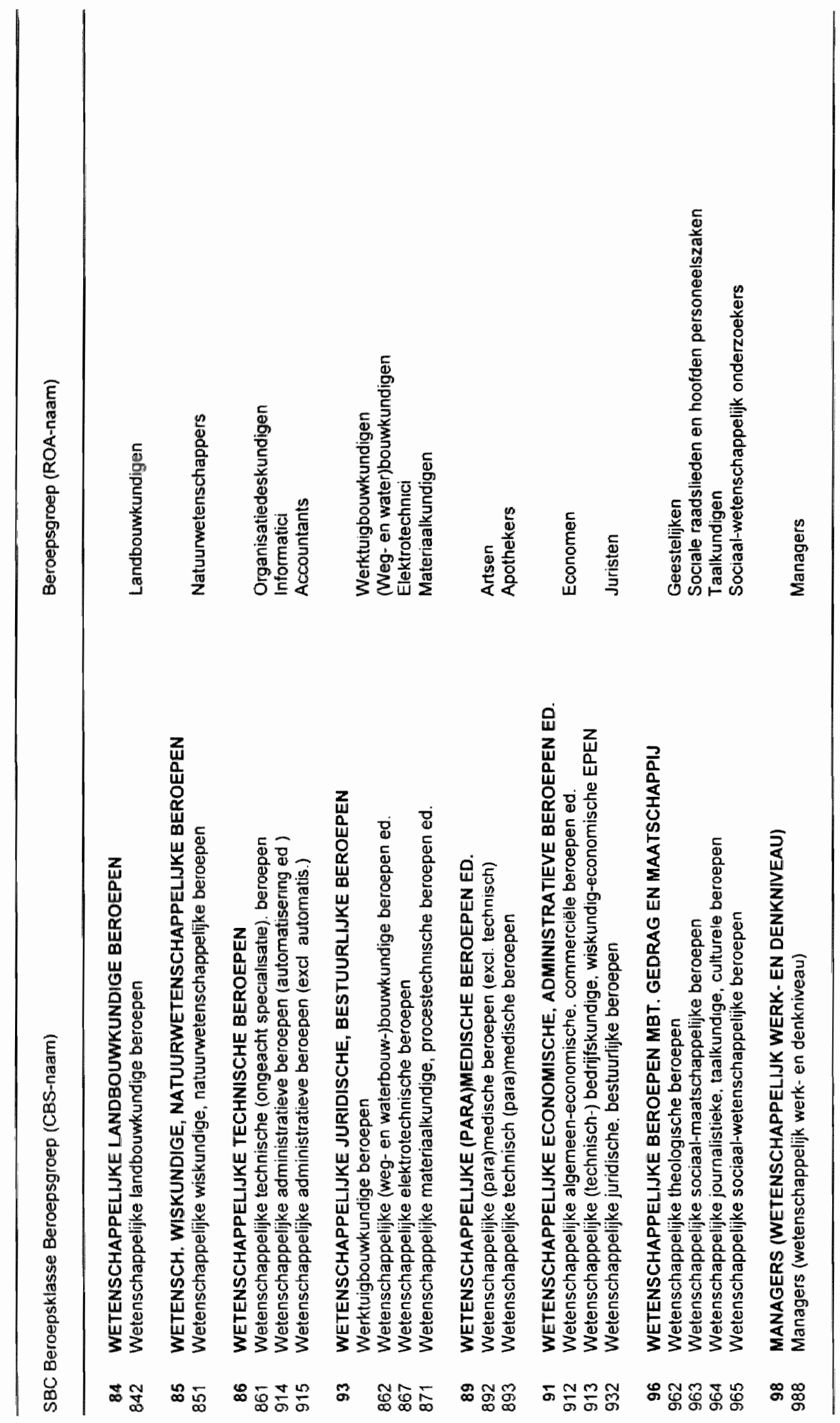




\section{Beknopte Bedrijfsclassificatie SBI '93}

Nr. Bedrijfscluster

Landbouw en visserij

2. Voeding

3. Chemie

4. Metaal en elektrotechniek

5. Overige industrie

6. Energie

7. Bouw en onroerend goed

8. Handel en reparatie

9. Transport en communicatie

10. Bank- en verzekeringswezen

11. Horeca en zakelijke dienstverlening

12. Kwartaire diensten

13. Overheid en onderwijs

14. Overig
SBI ' 93

01000-02999, 05000-05999

15000-16999

24000-25999

$27000-36099,36200-36599,36700-36999$

17000-22999, 26000-26999, 36100-36199,

$36600-36699$

10000-11999, 14000-14999.

23000-23999, 40000-41999,

45000-45999, 70000-70999.

50000-50402, 50500-54999

$60000-64999$

$65000-67999$

55000-55999, 71000-72999,

74000-74999, 90000-90999,

92400-92799, 93000-95999,

73000-73999, 85000-85999,

91000-91999, 92000-92399.

75000-75999, 80000-80999.

99000-99500 



\section{Uitgebreide Bedrijfsclassificatie SBI '93}

1. Tuinbouw

2. Veehouderij

3. Akkerbouw, bosbouw en visserij

4. Vlees-en visverwerking

5. Overige voedingsproducten

6. Drank en tabaksproducten

7. Basischemie

8. Eindproducten chemie

9 . Kunststofverwerking

10. Basismetaal

11. Metaalproducten

12. Machine-industrie

13. Elektrotechniek

14. Transportmiddelen

15. Textiel

16. Hout-en bouwmaterialen

17. Papier

18. Grafische industrie

19. Energie

20. Bouw

21. Exploitatie van onroerend goed

22. Handel en reparatie

23. Scheep-en luchtvaart

24. Weg-en railvervoer

25. Communicatie

26. Bankwezen

27. Verzekeringswezen

28. Horeca

29. Zakelijke dienstverlening

30. Overige commerciele dienstverlening

31. Gezondheidszorg

32. Overige kwartaire diensten

33. Onderwijs

34. Overheid

35. Overig
01120-01199

$01200-01599$

00001-01119, 02000-02999.

05000-05999

$15000-15299$

$15300-15899$

15900-16999

24000-24199

24200-24999

25000-25999

27000-27999

28000-28999, 36000-36099

$36200-36599,36700-36999$

29000-29999

30000-33999

34000-35999

17000-19999

20000-20999, 26000-26999

$36100-36199,36600-36699$

21000-21999

22000-22999

10000-11999, 14000-14999,

23000-23999, 40000-41999

45000-45999

70000-70999

50000-50402, 50500-52999

61000-62999

$60000-60999,63000-63999$

64000-64999

$65000-65999,67000-67199$

$66000-66999,67200-67999$

55000-55999

71000-72999, 74000-74999

90000-90999, 92400-92799

93000-95999

85000-85999

73000-73999, $91000-91999$

92000-92399

$80000-80999$

75000-75999, 99000-99500 